\title{
ASSESSMENT OF RESEARCH NEEDS FOR OIL RECOVERY FROM HEAVY-OIL SOURCES AND TAR SANDS
}

FOSSIL ENERGY RESEARCH WORKING GROUP - IIIA ( FERWG-I I IA)

Submitted by: S. S. Penner, Chairman of FERWG Energy Center and Department of Applied Mechanics and Engineering Sciences University of California, San Diego La Jolla, California 92093

Contract Sponsors: DOE Office of Energy Research, Fossil Energy, Resource Applications, Environment. DOE Program Managers: J. F. Kaufmann, R. Roberts, and J.J.G. Stosur. DOE Contract Number DE-AC01-79ER10007. 


\section{DISCLAIMER}

This report was prepared as an account of work sponsored by an agency of the United States Government. Neither the United States Government nor any agency thereof, nor any of their employees, make any warranty, express or implied, or assumes any legal liability or responsibility for the accuracy, completeness, or usefulness of any information, apparatus, product, or process disclosed, or represents that its use would not infringe privately owned rights. Reference herein to any specific commercial product, process, or service by trade name, trademark, manufacturer, or otherwise does not necessarily constitute or imply its endorsement, recommendation, or favoring by the United States Government or any agency thereof. The views and opinions of authors expressed herein do not necessarily state or reflect those of the United States Government or any agency thereof. 


\section{DISCLAIMER}

Portions of this document may be illegible in electronic image products. Images are produced from the best available original document. 


\section{ABSTRACT}

The Fossil Energy Research Working Group (FERWG), at the request of J.W. Mares (Assistant Secretary for Fossil Energy) and A. W. Trivelpiece (Director, Office of Energy Research), has reviewed and evaluated the U.S. programs on oil recovery from heavy oil sources and tar sands. These studies were performed in order to provide an independent assessment of research areas that affect the prospects for oil recovery from these sources. This report summarizes the findings and research recommendations of FERWG. 
Professor Sidney . Benson, Co-Director Hydrocarbon Research Institute University of Southern California Los Angeles, California 90007 (213) 743-2030

Dr. Frederick $W$. Camp

Manager of Technology

Synthetic Fuels Division

Sunoco Energy Development Company

12700 Park Central Place, Suite 1500

Dallas, Texas 75251

(214) $385-5030$

Professor Jon Clardy

Department of Chemistry

Baker Laboratories

Cornell University

Ithaca, New York 14853

(607) 256-7583

Dr. John Deutch

Department of Chemistry, Room 6-123

Massachusetts Institute of Technology

Cambridge, Massachusetts 02139

(617) 253-1479

Mr. John M. Hopkins, President (alternate member with A. E. Kelley)

Energy Mining Division, Room 406

Union Oil Company of California

461 South Boylston Street

Los Angeles, California 90017

(213) $977-6437$

Mr. Arnold E. Kelley, Vice President (alternate member with J.M. Hopkins)

Engineering and Development

Union Science \& Technology Division

Union Oil Company of California

P.O. Box 76

Brea, California 92621

(714) 528-7201

Dr. Richard R. Lessard, Director (alternate member with $F$. $X$. Mayer)

Coal Research Laboratory

Baytown Research \& Development Division

Exxon Research \& Engineering Company

P.O. Box 4255

Baytown, Texas 77520

(713) 428-5764

Mr. Francis X. Mayer, Engineering Advisor (alternate member with R. R. Lessard)

Exxon Research \& Development Laboratory

P.O. Box 2226

Baton Rouge, Louisiana 70821

(504) 359-7644

Professor Alex G. Oblad

Department of Mining \& Engineering

University of Utah

Salt Lake City, Utah 84112

(801) $581-6647$
Professor S. S. Penner (FERKG Chairman) Director, Energy Center, B-010

University of California, San Diego

La Jolla, California 92093

(714) 452-4284

Professor John Ross

Department of Chemistry

Stanford University

Stanford, California 94305

(415) 497-9203

Dr. Robert P. Sieg, Manager (a)ternate member with J. R. Thomas and L. T. Thrasher)

Synthetic Fuel Division

Chevron Research Company

P.O. Box 1627

Richmond, California 94802

(415) 620-3000, ext. 2762

Dr. William C. Skinner, Manager (alternate member with P. B. Neisz and D. D. Whitehurst)

Reservoir Exploitation Research \& Technical Service

Mobil Research \& Development Corp.

Field Research Laboratory

P.O. Box 900

Dalias, Texas 75221

(214) 333-6111

Dr. John R. Thomas, President (alternate member with R. P. Sieg and L. W. Thrasher

Chevron Research Company

P. O. Box 1627

Richmond, California 94802

(415) 620-3000, ext. 4051

Dr. Lawrence $w$. Thrasher, Vice President (alternate member with R. P. Sieg and J. R. Thomas)

Production Research Department

Chevron Oil Field Research Company P.O. Box 446

La Habra, California 90631

(213) 694-7000 ext. 7765

Dr. Paul B. Weisz, Manager (alternate member with $\mathbb{W}$. C. Skinner and D. D. Whitehurst)

Central Research Division

Mobil Research \& Development Corp.

P.O: Box 1025

Princeton, New Jersey 08540

(609) 737-3000

Dr. D. Duayne Thitehurst, Manager (alternate member with $W$. C. Skinner and P. B. Weisz)

Coal and Heavy Liquids

Central Research Division

Mobil Research \& Development Corp.

P.O. BOX 1025

Princeton, New Jersey 08540

(609) 737-3000 
Dr. Harry Robert Anderson

U.S. Department of Energy

FE-32, GTN, Fossil Energy

Washington, D.C. 20545

Mr. John F. Kaufmann

Deputy Associate Director for

Program Analysis

Office of Energy Research, A1-4000

U.S. Department of Energy

Tashington, D.C. 20545

(301) 353-2951

Dr. Arthur E. Lewis, I-207

Oil Shale Project Manager

Lawrence Livermore National Laboratory

University of California

P.O. Box 808

Livermore, California 94550

(415) 422-6453

Dr. Robert Roberts

Acting Director for Advanced

Research and Technology

Office of Fossil Energy

FE-60 C-171, GTN

U.S. Department of Energy

Tashington, D.C. 20545

(301) 353-2786

Dr. J. J. George Stosur

Director, Office of Oil

U. S. Department of Energy

MS D-107 GTN

Washington, D.C. 20545

(301) 353-2700 
FOREWORD

During the terminal phase of operation, FERWG was asked by J.W. Mares (Assistant Secretary for Fossil Energy, DOE) and A. W. Trivelpiece (Director, Office of Energy Research, DOE) to conduct an "independent assessment providing for identification of research needs associated with oil recovery from heavy oil sources and tar sands." The DOE objectives for FERWG are defined in Appendix A. This assessment of oil-recovery technologies was administered through a DOE contract to the Energy Center at the University of California, San Diego, in La Jolla, California.

Members of FERWG performed an extensive schedule of site visits to process development units and facilities on tar sands and heavy oil sources, as well as to university and DOE laboratories, in order to familiarize themselves with current and planned research programs. Site-visit reports and evaluations, with emphasis on identified process and fundamental research needs, were prepared by participating FERWG members after each site visit. These site-visit reports are reproduced in Appendix $B$.

FERWG members held discussions with the Assistant Secretary for Fossil Energy, the Director of the Office of Energy Research, members of their staffs, DOE program managers, directors of laboratories and development engineers who are involved in oil recovery research and development ( $R \& D$ ) in both industrial and governmental organizations, and with universitybased scientists and engineers who perform research related to oil recovery from heavy oil sources and tar sands. In addition, FERWG received written comments in response to the draft letter reproduced in Appendix A.

The Executive Summary is followed by an introductory discussion (Chapter 1 ) in which we present the FERWG study objectives, describe essential operating features of selected processes for oil recovery from heavy oil sources and tar sands, and summarize the research recommendations derived from our site-visit evaluations. More detailed research recommendations are discussed in Chapters 2-7.

The costing of oil recovery from heavy oil sources and tar sands formed the subject of a separate workshop. The results derived from these activities are summarized in chapter 7 . 
Our research recommendations cover a wide spectrum of activities in recovery technologies for tar sands and heavy oils, ranging from fundamental science to process engineering. They have not been constructed to satisfy the desires of either the scientist or the development engineer. Adequate research support for programs relating to recovery technologies for tar sands and heavy oils may aid commercial implementation of the right technologies over the long term and may also be valuable in the definition and identification of new or different technologies that merit commercialization.

The members of FERWG acknowledge with thanks the advice and assistance given by many individuals in government, industry and the universities. The following people, among others, have contributed to our discussions, evaluations, and final recommendations: F. Allhoff (DOE); J.Allsup (DOE/BETC); C. W. Bowman (Alberta Oil Sands Technology and Research Authority [AOSTRA]); W. E. Brigham (Stanford University); J.W. Bunger (University of Utah); F. W. Burtch (DOE/BETC); M. A. Carrigy (AOSTRA); E. L. Cook (Mobil Research); A. Crawley (DOE/BETC); P. Dana (DOE/LETC); G. W. Dean (DOE/Oakland); A. Decora (DOE/LETC); J. Defir (Alberta Environment); J. Dooley (DOE/BETC); J. H. Duerksen (Chevron Research); R. Eson (Chemical Oil Recovery); R. G. Evans (Energy Resources Conservation Board, Alberta); J. Fitch (Chemical Oil Recovery); R. L. Folstein (DOE/BETC); F. Ghassemi (University of Southern California); W. Good (DOE/BETC); L. L. Handy (University of Southern California); F. V. Hanson (University of Utah); B. Harney (DOE); R. V. Henning (Alberta Municipal Affairs); L. G. Hepler (AOSTRA); B. G. Holmes (Mobil Production Research); F. Holzeiz (LLNL); A. Holzer (LLNL); J. Jennings (Gulf Research); H. R. Johnson (DOE/BETC); L. Johnson (DOE/LETC); R. Jones (American Petroleum Institute); G. Y. Jordy (DOE); N. Kilbourn (Sunoco Energy Development); C. A. Koch (Koch and Associates); L. Kronenberger (Exxon USA); Y. Ksander (The Engineering Societies, Commission on Energy); L. Lake (University of Texas); H. Lechtenberg (DOE/Oakland); A. Leighton (DOE/Oakland); E. J. Lievens (DOE); E. W. Malmberg (Sun Production Company); L. C. Marchant (DOE/LETC); C. Mathews (Shell Research); J. D. Miller (University of Utah); M. Misra (University of Utah); L. O'Brien (Union Oil); E. L. Oshlo (Conoco); T. Owen (DOE/LETC); H. W. Parker (The Engineering Societies, Commission on Energy); R. Y. Pei (Rand Corp.); G. Peterson (DOE/Oakland); K. E. Phillips (Rand Corp.); R. S. Phillips (AOSTRA); R. Porter (DOE/BETC); R. Poulson (DOE/LETC); M. Ray (DOE/BETC); R. E. Robertson, III (DOE); L. Romanowski (DOE/LETC); J. D. Seader (University of Utah); W. E. Showalter (Union Oil); W. H. Somerton (University of California, Berkeley); G. Standley (DOE/Oakland); B. Sudduth (DOE/LETC); D. Sutterfield (DOE/BETC); L. R. Turner (AOSTRA); V. N. Venkatesan (University of Utah); D. Ward (DOE/ BETC); J. P. Watson (DOE); J. Weber (DOE/LETC); T. Wesson (DOE/ BETC); J. F. Norton (Radian Corp.); W. Winsauer (Exxon); and T. F. Yen (University of Southern California). 
TABLE OF CONTENTS

\author{
LIST OF ILLUSTRATIONS \\ LIST OF TABLES \\ EXECUTIVE SUMMARY \\ NOMENCIATURE
}

$\underline{\text { Page }}$

CHAPTER 1 OVERVIEW OF OIL RECOVERY FROM HEAVY OIL SOURCES AND TAR SANDS

1.2 Oil Recovery from the Tar Sands of Alberta

1.2.1 The GOCS (Suncor) Recovery and Upgrading Procedure of Oil from Tar Sands (Clark Process )

1.2.2 The Syncrude Recovery and Upgrading Procedure of Oil from Tar Sands

1.3 Oil Recovery from the Tar Sands of Utah 19

1.3.1 Introduction

19

1.3.2 The Utah Resource Base

1.3.3 Chemical Analyses of Utah Tar Sands

23

1.3.4 Recovery Technology

23

1.3.5 Hot-Water Recovery Process

26

30

1.3.6 Fluid Bed Thermal Recovery

1.3.7 Upgrading of the Recovered Bitumens

31

1.3.8 Pilot Plant Studies

32

1.3.9 In Situ Recovery

1.3.10 Economics of Bitumen Recovery from Utah Tar Sands

1.2.11 Environmental Aspects of Tar Sand Development

32

35

35

38

1.4 Research Recommendations on Oil Recovery from Tar Sands Derived from Site Visits and Discussions

1.5 Selected Examples of Current Studies Relating to

Oil Recovery from Heavy-Oil Sources and Tar Sands 
TABLE OF CONTENTS (Continued)

$\underline{\text { Page }}$

CHAPTER 2 RESOURCE ASSESSMENTS

2.1 Introduction and Definitions 47

2.1.1 Introduction 47

2.1.2 Definitions of Heavy Oil Classifications 50

2.2 Available Physical Property Data on Tar Sands and Heavy Oils 56

2.3 Resources and Reserves of Heavy Oils 61

2.3.1 Definitions 61

2.3.2 Resources of Heavy Oils and Tar Sands 62

2.3.3 Ultimate Recovery of Heavy Oils (Proved
Reserves)

$\begin{array}{lll}2.4 & \text { Recommendations } & 78\end{array}$

CHAPTER 3 PROCESS RESEARCH RELATING TO OIL RECOVERY FROM TAR SANDS AND HEAVY OIL SOURCES 80

3.1 Surface Mining and Aboveground Processing of Tar

Sands
3.2 In Situ Processing of Tar Sands and Heavy Oil
Sources

3.2.1 Intensive Oil and Rock Properties 83

3.2.2 Reservoir Descriptions and Modeling 84

3.2.3 Tar-Sands Processing 85

3.2.4 Thermal Recovery with Steam 85

3.2.5 Thermal Recovery with Combustion 86

3.2.6 Novel Techniques 86

3.2.7 Process Research Relating to Heavy Oil 88

3.2.8 Fundamental Supporting Research 88

3.2 .9 Transportation of Bitumen-Water-Sand
Slurries

3.2.10 Down-Hole Steam Generation 89

3.2.11 High-Temperature Packers and Insulation
Systems

3.2.12 Reservoir Properties Research 90

3.2.13 Compatibility Studies 90 
TABLE OF CONTENTS (Continued)

$\underline{\text { Page }}$

CHAPTER 4 ENVIRONMENTAL ASPECTS

91

4.1 Air Quality

4.2 Water Quality

4.3 Land

92
94

96

CHAPTER 5 FUNDAMENTAL RESEARCH ON OIL RECOVERY FROM HEAVY OIL SOURCES AND TAR SANDS

5.1 Basic Research Policy

5.2 Examples of Basic Research Relating to Oil Recovery

from Heavy Oil Sources and Tar Sands

5.3 Resource Characterization

97

5.4 Thermal Recovery Methods

5.5 Chemical Additives

5.6 Environmental Problems

$\begin{array}{lll}\text { CHAPTER } 6 \text { UPGRADING AND REFINING } & 106\end{array}$

$\begin{array}{lll}6.1 & \text { Introduction } & 106\end{array}$

6.2 Residuum Conversion Alternatives 107

6.3 Research Needs 111

CHAPTER 7 COSTING OF OILS FROM EOR AND UTAH TAR SANDS 112

Appendix 7-I Costing of Oil from Heavy Oil Sources and Tar Sands

A7-I.1 Application of Statistical Cost and Performance Methodology to Enhanced Oil Recovery Technologies

A7-I.2 The Costs and Performance for Pecovering and Processing Utah Tar Sands and the Relevance of the GCOS and Syncrude Experience

APPENDIX A FERWG-IIIA STATEMENT OF WORK DRAFT LETTER TO REVIEWERS 


\section{LIST OF ILLUSTRATIONS}

Figure Number

Page

1.1-1 Schematic diagram of a well-developed steam-

1.1-2 The in-situ combustion process

1.2-1 Tar sand sites in the state of Alberta in Canada

1.2.1-1 The bitumen recovery scheme pioneered by GCOS and used by Suncor and Syncrude

1.2.1-2 The GCOS upgrading process for bitumen recovered from tar sands

1.3.1-1 Major tar sand deposits in the state of Utah

1.3.3-1 Arrhenius-type plot illustrating the effect of temperature on viscosity for bitumens from various Utah tar sand deposits

$1 \cdot 3 \cdot 3-2$

Particle size distributions of sands from Tar Sand Triangle, P. R. Spring, Sunnyside, and Asphalt Ridge in Utah

$1.3 \cdot 6-1$

1.3.8-1 Pilot plant for bitumen recovery by the University of Utah hot-water process

$1.5-1$

$1.5-2$

Oil pools and oil sands deposits of Alberta

Schematic cross-section (compare Fig. 1.5-1) between the western boundary of the Peace River deposit and the eastern boundary of the Athabasca deposit south of Fort McMurray

$1.5-3$ Hydrocracking and separation scheme

2.1.2-1 Geologic cross profile, Asphalt Ridge Area, Utah

$2.1 \cdot 2-2$

Schematic geological E-W cross section showing the geological setting of the Athabasca Tar Sands

2.1.2-3 Diagrammatic section through Edna Tar Sands, California

2.1.2-4 NW-SE geological section through Trinidad Asphalt Lake Area

2.3.2-1 Tar sand occurrences in the U.S.

2.3.2-2 Geographical location of heavy oil fields in the United States

2.3.2-3 States containing heavy crude oil included in this study

2.3.3-1 Surface-mineable oil sand deposits in the Athabasca area 


\section{LIST OF TABLES}

Table Number

Page

1.3.1-1 Deposits of bitumen-bearing rocks in the United States with resources over

$1 \times 10^{6} \mathrm{~B}$

20

1.3.2-1 Tar-sand deposits in Utah

24

1.3.2-2 Estimates of mineable tar sands assuming 3 cubic yards of overburden per $B$

1.3.3-1 Typical bitumen properties for general groups of tar-sands deposits

1.3.7-1 Comparison of yield and conversion results for the primary processing of Asphalt Ridge bitumen

1.3.10-1 Economic assessment for recovery of 5,000 BPD of syncrude

$1.4-1$

Summary of research recommendations derived from site visits and discussions

$2 \cdot 1 \cdot 1-1$

Variations in viscosity with API gravities

2.1.2-1

Classification of heavy oils

A representative Bureau of Mines data report

57

2. $2-2$

Example of data retrievable from API tapes

$2.2-3$

Desirable compositional and production data for heavy oils for inclusion in heavy crude assay databanks

58

$2 \cdot 3 \cdot 2-1$

Deposits of bitumen-bearing rocks in the U.S. with resources over $1,000,000$ barrels

$2.3 \cdot 2-2$

United States heavy crude oil resources than 200API with some mobility)

$2.3 \cdot 2-3$ Thermal recovery projects in the United States

$2.3 \cdot 3-1$

Ultimate recoverability of tar-sand bitumen in Alberta

$6.2-1$

Residuum conversion alternatives

6. 2-2

Residuum conversion

by-products 
EXECUTIVE SUMMARY

The Role of Federal Funding in Oil Recovery from Tar Sands and Heavy-Oil Sources

Oil recoveries from heavy-oil sources and Canadian tar sands represent currently commercial procedures, as is evident from the fact that about $300,000 \mathrm{BPD}$ of heavy oils and 200,000 BPD of tarsand oils are currently being produced. While only relatively small pilot plants are in operation or planned for oil recovery from Utah and other U.S. tar sands, several different recovery procedures are generally viewed to be suitable for near-term commercialization. The particular role of federal funding therefore requires especially careful definition.

We have identified two very different primary areas of concern that should properly be addressed through federally funded R\&D programs.

The first area of concern relates to implementation of effective but non-obstructive environmental controls at each of the many ( 2500$)$ sites where secondary and tertiary oil recovery is implemented, as well as at each of the many potential sites in the U.S. where oil recovery from tar sands may be practiced on a commercial scale. While we recognize important site-specific variations, the very large number of actual recovery areas implies that only a relatively small set of control measurements will be useful and that each of these will, in turn, be associated with a large number of potential field sites for application. The definition of measurement criteria and the identification of control parameters to assure resource recovery under acceptable, nonobstructive constraints will require careful monitoring at many

sites, a substantial data base, and knowledgeable employees to assist policy makers in writing and enforcing appropriate environmental control legislation. Federal funding is needed to provide knowledge in this area and to establish wise environmental controls.

The second area of concern relates to the logical development of field-recovery technologies by industrial firms on their own lands or on leased lands. The judgement of when and how to proceed will necessarily and properly be made by an industrial firm on the basis of financial returns during the anticipated life of the operating facility. The efficiency of resource recovery enters parametrically because it is needed to make estimates of return on investment. Economically viable enterprises will generally be defined in terms of partial resource recovery. Termination of commercial operations will accompany failure to obtain adequate returns on investment. Implementation of new and more costly recovery processes can oniy be expected to occur if these are judged to be competitive with alternative investments. 
Generally applicable areas of R\&D problems appear to be suitable for federal support in order to define U.S. estimates of potentials for conversion of resources to reserves.

Significant progress on environmental impact assessments and control, as well as improved resource recovery, will be achieved over the long term as a result of fundamental research programs dealing with all aspects of these technologies. Commercial implementation of entirely new recovery procedures may be hoped for and will be based on technologies advanced by fundamental research programs.

We summarize below important research areas for which more detailed justification is presented in the following chapters.*

A. Resource Assessments (Chapter 2)

- The magnitudes of U.S. tar-sand and heavy oil resources and reserves should be assessed on a systematic basis, both in terms of quantity and the physical and chemical properties of the oil in place.

B. Process Research Relating to Oil Recovery from Tar Sands and Heavy-Oil Sources (Chapter 3)

- Develop basic information required for modeling in situ and aboveground recovery procedures and involving the use of $\mathrm{CO}_{2}$, steam, surfactants, caustic flooding, or combustion. These models should describe sweep and conversion efficiencies.

- Develop improved procedures for injection of steam, additives, and combustion control.

- Implementation of thermal processing techniques will require improved methods for solids removal from liquids, gases, and combustion of coke on the pyrolyzed sand.

- For improved in situ combustion recovery, the following studies are needed: better designs for high-temperature packers and insulation systems, steam generation in the oil formations, cleanup and disposition of low-Btu gas, and cost-benefit studies on the use of oxygen-enriched air.

\footnotetext{
* Research recommendations represent a general concensus but each statement is not necessarily endorsed by all FERWG members.
} 
- Such innovative studies as radiofrequency heating, mineassisted steam injection, and $\mathrm{CO}_{2}$ huff-and-puff merit support.

- Other important studies include sand control to achieve lasting oil-production improvements, transportation of bitumen-water-sand slurries, and the augmented use of down-hole steam generators. The presumed advantages of sulfur removal and enhanced oil yield with downhole steam generation should be verified.

Process research is properly the primary responsibility of industry. However, a federal role may be appropriate in joint efforts on high-risk studies with significant potential benefits to the entire industry.

C. Environmental Studies (Chapter 4)

- Because environmental studies are strongly site-specific and total production may ultimately be limited by emissions regulations for $\mathrm{SO}_{\mathrm{X}}$ and $\mathrm{NO}_{\mathrm{X}}$, research to improve scrubber technologies should be supported.

- Improved understanding is needed of chemical processes involving organic sulfur and nitrogen compounds and of air dispersion in orographic regions.

- Hydrocarbons emitted to the atmosphere in appreciable concentrations require characterization and toxicological evaluation. We expect refined oils to be comparable to conventional petroleum products although newly formed crudes may represent toxicological hazards that require careful control.

- Long-term environmental constraints must be quantified before they limit commercial developments.

- Fundamental studies are needed on water treatment under conditions encountered in regions where oil is recovered from tar sands or heavy oil sources on commercial scales. Less expensive procedures than are now available should be sought: Methods are needed for the characterization and removal of dissolved organic compounds.

\footnotetext{
* For further discussions, especially considerations of safety, health, biological, and toxicological issues, we refer to the following recently completed study: "Synfuels Facilities Safety," National Research Council, Assembly of Engineering, Committee on Synfuels Facilities Safety, Washington, D.C., April 1982.
} 
- The use of alkyl sulfonates in EOR may lead to special control requirements in order to alleviate environmental problems. Chemical studies should be performed to define mechanisms and rates in the mobilization of oils by micellar additives and heating with combustion products. Studies should be supported on the migration and fate of combustion products formed from bitumens.

D. Fundamental Research (Chapter 5)

- A long range, federally sponsored basic research program in oil recovery is both appropriate and necessary.

- A level of effort in the range of 30 to 60 (1981) millions of dollars per year has been judged to be justifiable by some FERWG members, while others do not believe that a convincing case has been made for substantial governmental support.

- Important areas for these studies include:

(a) resource and reservoir characterization;

(b) fundamentals of flows in porous media;

(c) studies in physical chemistry, including thermodynamics and the surface behavior of oil/water/steam/ $\mathrm{CO}_{2} /$ sand systems;

(d) problems of corrosion related to (c);

(e) environmental problems encountered in recovery processes.

E. Upgrading and Refining (Chapter 6)

- Refining technologies currently used on heavy petroleum crudes can be employed with confidence on heavy oils and bitumens. The development of improved processes may profit from better understanding of

(a) molecular structures and compositions of residua;

(b) mechanisms of asphaltene conversions;

(c) processes for the removal of sulfur and metals; 
(d) kinetic studies on coke gasification;

(e) mechanisms involving gasification catalysts;

(f) methods of utilizing high-sulfur cokes and tars;

(g) coke desulfurization and utilization as synthetic feedstock.

F. Cost Estimations (Chapter 7)

Uncertainties in costing will be reduced by process $R \& D$ and, in the view of some but not all of the FERWG members, perhaps also by fundamental research.

\section{G. Prioritization of Federal Research Expenditures}

- Highest priority is assigned to the development of improved methods for resource characterization, process modeling, and the relation between resource characteristics and recovery costs. Basic studies leading to less costly control procedures for $\mathrm{SO}_{\mathrm{x}}$ and $\mathrm{NO}_{\mathrm{x}}$ and to improved fundamental understanding of flows in porous media also require urgent attention. 


\section{NOMENCLATURE}

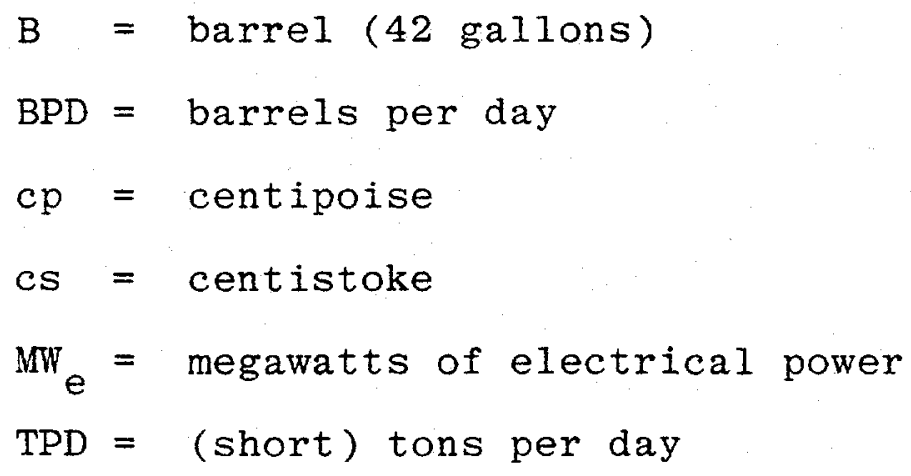




\section{CHAPTER 1 \\ OVERVIEW OF OIL RECOVERY FROM HEAVY OIL SOURCES AND TAR SANDS}

Recovery of oils from heavy oil sources and tar sands is needed in order to satisfy near-term and intermediate term goals for the U.S. to augment domestic fuel supplies for the transportation sector. Heavy oils currently contribute about $3 \times 10^{5}$ BPD to U.S. supplies, of which about $90 \%$ is recovered by steam flooding and $10 \%$ by underground combustion. While oil recovery from tar sands in the U.S. has not been implemented on commercial scales, oil recovery by surface processing of tar sands in Alberta, Canada, currently amounts to about $2 \times 10^{5} \mathrm{BPD}$ and is being expanded rapidly.

\subsection{Oil Recovery from Heavy Oil Sources}

A readable tutorial on enhanced oil recovery has been published recently and we refer to this paper for background information concerning goals, methods and achievements. 1 Here, we content ourselves with a brief summary of essential features of these processes.

A highly simplified schematic diagram of a well developed steam-flood pattern is shown in Fig. 1.1-1. The initial reservoir temperature is raised by contacting with the steam flood (generally, the steam has a quality well above zero), which is preferably injected near the base of the reservoir. While the contacted oil is heated, the steam is cooled and condensed, depending on reservoir conditions. After some time, the bed permeability is effectively reduced and the steam will then tend to override the productive oil layer with a concomitant decrease

1. M. Doscher, "Enhanced Recovery of Crude Oil," American Scientist 69, 193-199 (1981). 


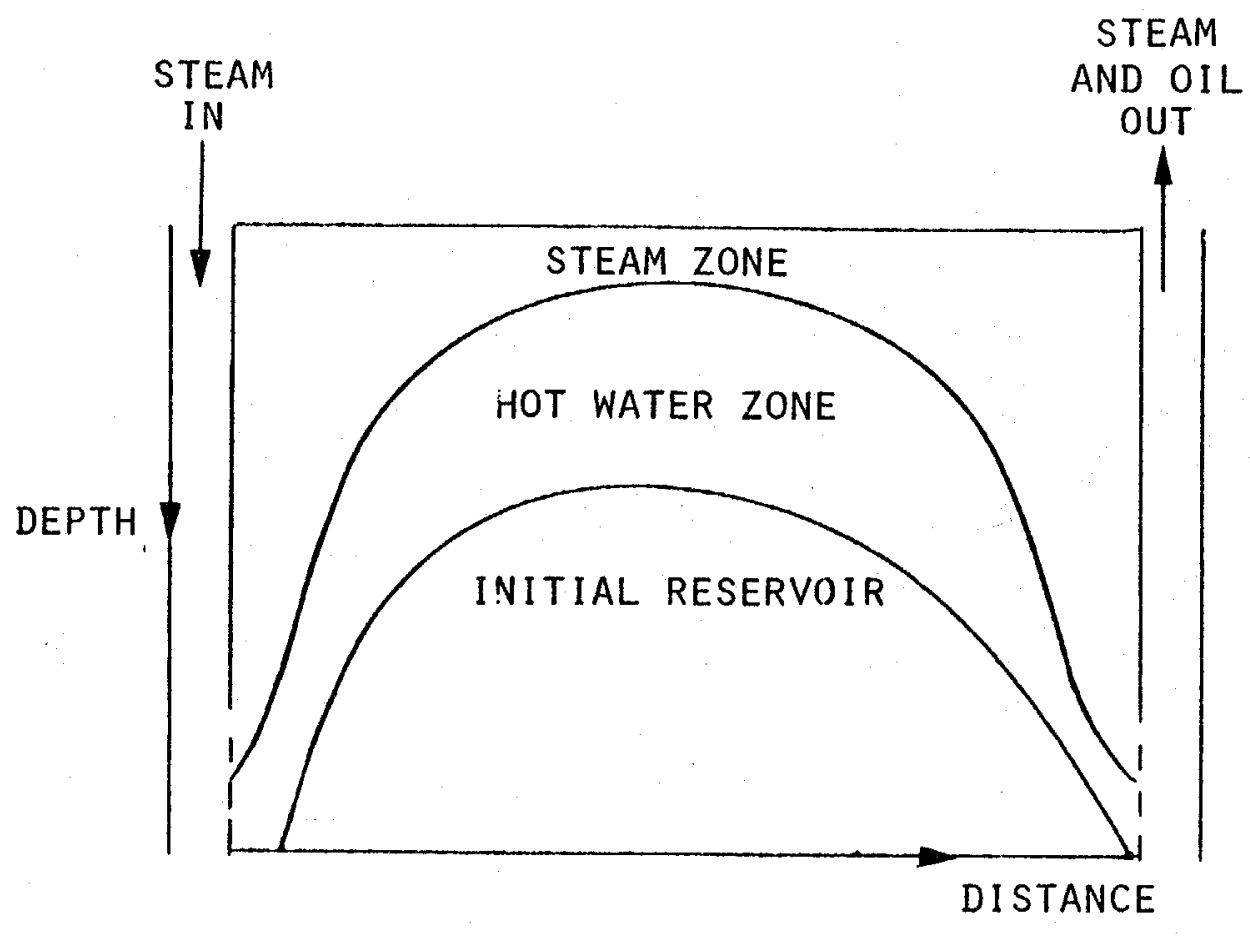

Fig. 1.1-1 Schematic diagram of a well-developed steamflood pattern. 
in productivity (see Fig. 1.1-1), depending on the paths taken by the steam between the injection and production wells. Also, when the steam loses less heat, it tends to be buoyed upward more by gravitational forces.

It is apparent that the physicochemical processes actually occurring during enhanced oil recovery (EOR) by steam injection are very complex and depend on many features and properties that are only poorly understood. A quantitative model of the efficacy of enhanced oil recovery would require the following types of information: physical properties of the oilbearing sands, including local values of permeability and porosity and proper constitutive equations as functions of temperature and pressure for these porous beds; quantitative descriptions of the geochemistry of oil-bearing sands and all other strata that are located between the injection and production wells; physicochemical data relating to mechanisms and rates of the surface processes that are involved in the movements of heavy oils through the formations as heat transfer from the steam is effected; thermophysical data allowing quantitative evaluations of rates of heat transfer from the steam (including thermal diffusivities, heat capacities, heats of adsorption and desorption, etc.); adequate understanding of the fluid dynamics in the flows of multiphase mixtures through non-uniform, porous media.

In practical applications, the problems are further complicated when additives are introduced with the steam in varying proportions (without or with underground combustion) to enhance the mobility of the oils that are to be recovered. Additives may be $\mathrm{CO}_{2}$, air with or without oxygen enrichment to facilitate combustion, surfactants to enhance removal of the heavy oils from the oil-bearing sands, etc. Additives have also been injected for the purpose of producing partial blockages of passageways in the steam override region in order to augment penetration of the productive beds by the injected steam or other material.

A schematic diagram showing the use of fireflooding in EOR is reproduced (compare $p . A B-157$ ) in Fig. 1.1-2. 


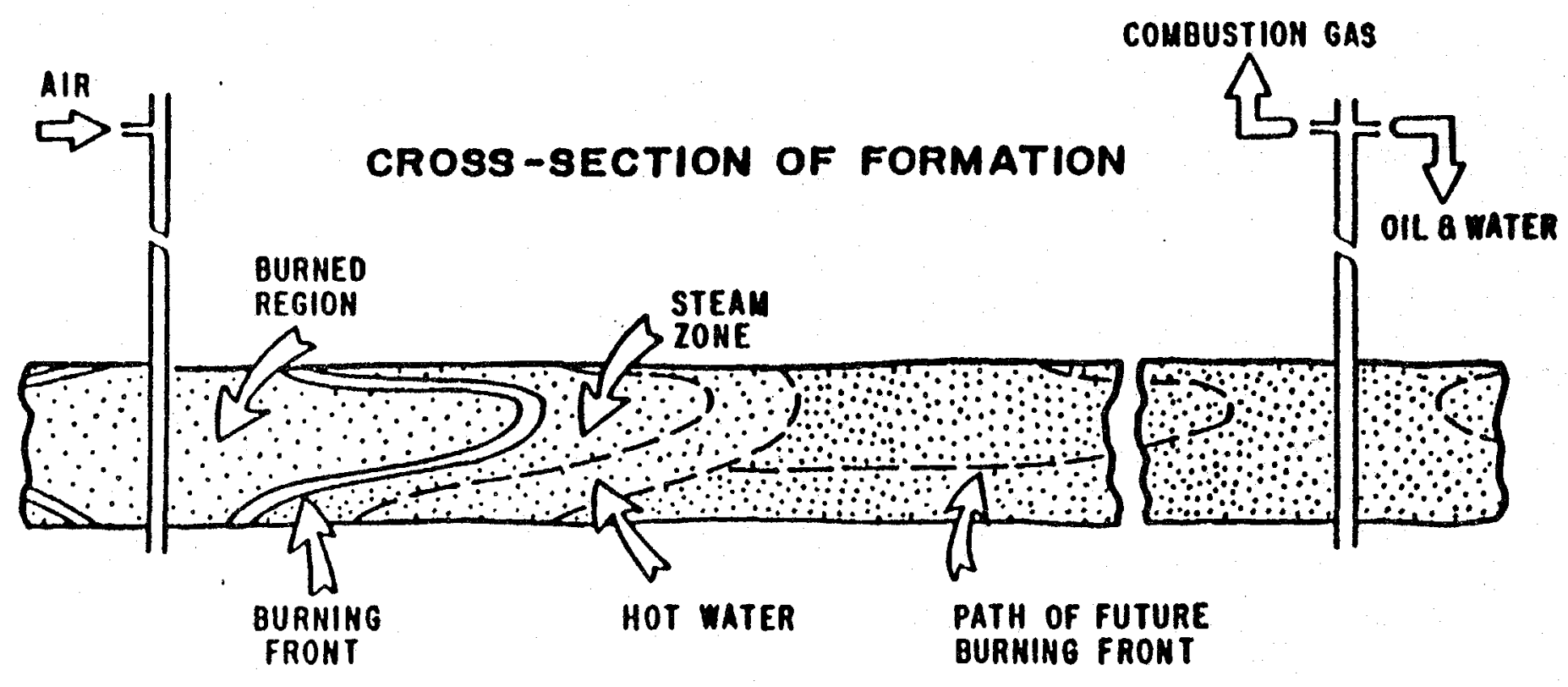

TEMPERATURE DISTRIBUTION

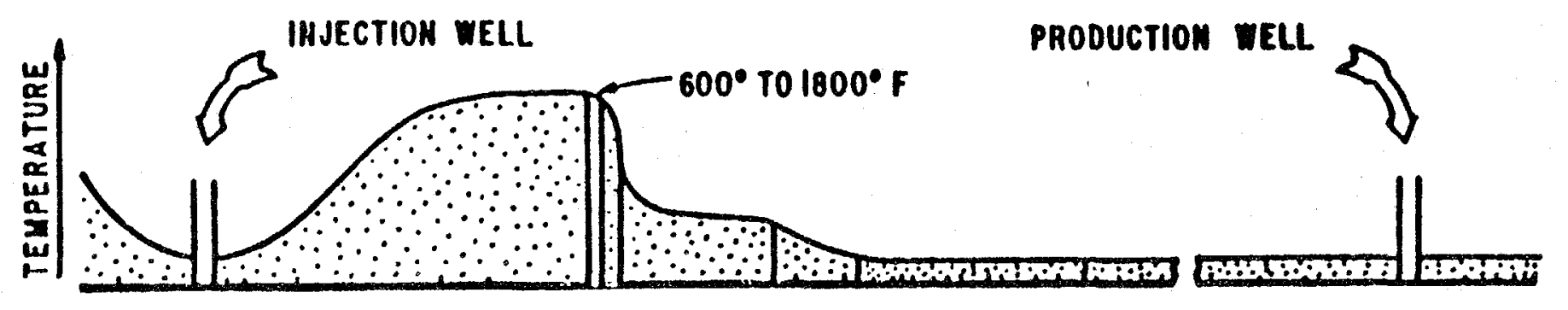

Fig. 1.1-2 The in-situ combustion process. 
A good overview of the status of current technology of EOR is provided by the conference proceedings prepared by the DOE Fossil Energy Division, San Francisco Operations, for the "1981 Heavy Oil/EOR Contractor Reports," July 28-30, 1981, San Francisco, California.* We refer to this report and to our site visit summaries appearing in the Appendix ( $A B$ ) for further information concerning the status of EOR.

The published studies indicate each of the following: numerous examples of successfully achieved heavy oil recoveries by industrial firms, which justify the view that we are dealing with commercially developed technologies; the use of simplified models and their partial verification in bench-scale and pilot-size tests; ingenious approaches by scientists and engineers in efforts to obtain quantitative models and understanding of the processes involved; incomplete understanding in commercial recovery schemes.

\subsubsection{Some Properties of Heavy Oils}

The following definitions are currently in use: (a) Heavy crude oil has a gas-free viscosity of 100 to $10,000 \mathrm{mPa}-\mathrm{s}$ (centipoise) inclusive at original reservoir temperature or a density of $943 \mathrm{~kg} / \mathrm{m}^{3}\left(20^{\circ}\right.$ API gravity) to $1,000 \mathrm{~kg} / \mathrm{m}^{3}$ (10 $0^{\circ}$ API gravity) inclusive at $15.6^{\circ} \mathrm{C}$ and atmospheric pressure. (b) Tar sand oil has a gas-free viscosity greater than $10,000 \mathrm{mPa}-\mathrm{s}$ at original reservoir temperature or a density greater than $1,000 \mathrm{~kg} / \mathrm{m}^{3}$ (1ess than $10^{\circ} \mathrm{API}$ gravity) at $15.6^{\circ} \mathrm{C}\left(60^{\circ} \mathrm{F}\right)$ and atmospheric pressure.

A variety of procedures is available for heavy oil processing, all of which involve desulfurization and nitrogen and metals removal steps, as well as hydrotreating. Carbon-to-hydrogen weight ratios are typically around 8 . Transportation and application requirements determine the needed severity of refining. Sediments from oil production or upgrading typically con-

\footnotetext{
*omments on this conference are contained in the Appendix, $A B-6$.
} 
tain many heterocyclic aromatics, including organic nitrogen compounds, with environmental and health effects varying from strongly deleterious to harmless. Additional new facilities may have to be built to upgrade heavy ends. The Appendix (cf. pp. $A B$ 213-241) to the site-visit report in $A B-5$ contains a summary of heavy feed upgrading options and shows the following important processing steps: for carbon rejection, fluid coking or flexicoking, delayed coking, deasphalting; with hydrogen addition, hydrodesulfurization and hydroconversion; process-combination options are hydrotreating and coking, hydrotreating with catalytic cracking, deasphalting with hydrodesulfurization, and pretreatment such as demetallization.

\section{1 .2 Some Previously Identified R\&D Needs}

Joint discussions (cf. Appendix AB-6) between FERWG members and representatives of the DOE Fossil Energy Division, San Francisco Operations, produced the listing of EOR R\&D needs enumerated below:

A. Steam Additives

The purpose of steam additives is to improve recovery efficiency with steam injection. Recovery efficiency will be improved if (a) greater sweep efficiency is achieved and (b) more oil is recovered from the swept volume. While flow models are available that have been serving as a basis for achieving increased recovery efficiency, each of the following fundamental areas of study has been inadequately explored: (a) physicochemical studies (including thermochemical and rate measurements) referring to interactions between steam, steam additives, and oil-bearing sands; (b) physicochemical studies involved in surface adsorption, desorption, and substitution; (c) effects of physical and chemical properties of multiphase fluid mixtures on flows through porous media; (d) the interplay between fluiddynamic phenomena and physicochemical properties (density, viscosity, surface properties) in producing channeling and 
instabilities during flows through porous media; (e) phase separations in steam-additive and oil-sand mixtures as functions of temperature and pressure; (f) studies of the mechanisms and rates of gel deposition on injection with steam and additives and of the subsequent degradation of encapsulated foams.

\section{B. Down-Hole Steam Generation}

Each of the following R\&D programs may contribute to better understanding and improved oil recovery in the long-term utilization of down-hole steam generators: (a) combustion research (including equipment changes, use of preheaters, recirculation, etc.) to allow direct utilization of oil-field crude in down-hole steam generation; (b) long-term environmental impact assessments (involving both gaseous effluents and residue stability) with down-hole steam generation; (c) quantitative studies on the efficacy of mixtures of steam and combustion products in enhancing oil recovery.

\section{Alkaline Floods}

The fundamental studies suggested by the use of alkaline floods for EOR are similar to those previously enumerated under additives. The key is mobility control of oil in an alkaline flood with appropriate use of surfactants to lead to oil-inwater or water-in-oil emulsions. Adequate control will minimize the consumption of caustic in the reservoir under conditions of extensive surfactant recovery. There is also an, associated requirement for water treatment.

\section{Mine-Assisted Steam Injection}

These studies relate especially to improved steam-contacting with the reservoir bed. There are uncertainties in every aspect of the processes involved: (a) the reservoir is inadequately characterized and space-dependent estimates are not available for porosity, oil in place, permeability, sur- 
face properties; (b) if the reservoir bed were adequately characterized, the flow of the reacting fluids through the porous beds could be properly characterized only if constitutive equations were available under reservoir conditions; (c) improved and remote diagnostic procedures are needed to follow the progress of steam floods with caustic and other additives through the reservoir.

The idea that directional drilling and horizontal injection at selected reservoir depths will improve oil recovery has practical appeal and the resulting measurements may be expected to lead to improved reservoir-performance models.

\section{E. Sand Control}

In practice, the uncontrolled flow of (spent) sand from unconsolidated reservoirs may represent a serious impediment to achieving lasting output improvements. Fundamental problems relate to the flow of reacting fluids through porous media, constitutive equations for the original sand and for the spent sand, and the fluid dynamics of multiphase flows through porous media under defined pressure, temperature, and composition gradients. Problems of this type cannot now be modeled under controlled conditions and invite long-term investigations by competent scientists.

\section{F. Thermal-Front Mapping}

In each of our previous FERWG studies, we have emphasized the importance of developing well-calibrated instrumentation for needed in situ diagnostics to allow sequential comparisons between field measurements and computer models designed to describe the physical phenomena under study. EOR offers particular challenges in this respect because of the lack of homogeneity in relatively inaccessible reservoirs. The suggested uses of high frequency electromagnetic and controlled source audio magnetotelluric mapping, as well as applications of tracer techniques and other procedures, merit support. Priority should be given to measurements with good spacial resolution 
that have been carefully calibrated under well defined conditions and adequately tested in inhomogeneous media. A wide range of properties (including steam quality, temperature, pressure, porosity, flow speeds, etc.) is of interest.

\section{G. High-Temperature Packers and Insulation Systems}

Naterials problems and studies bear on the design of packers to confine fluids in the well annulus. The high-temperature environments under which the packers must function for prolonged periods of time pose special problems. Of particular importance is maintenance of bottom-hole integrity with quantitative characterization of heat and other losses.

\section{H. In Situ Combustion}

Fireflooding involves combustion processes in porous, multi-phase media that have not been adequately studied and are accordingly poorly understood. The wide spectrum of fundamental phenomena involves exothermic oxidation reactions on porous beds, mass and heat transfer with mobilization of oil, and movement of the resulting multiphase mixtures through reservoirs. These represent a significant challenge to combustion scientists and reservoir modelers alike. A long-range, fundamental research effort in these fields merits support if fireflooding is to become more than an empirical field effort for enchanced oil recovery.

\section{Reservoir Properties Research}

This proposed program should emphasize the fluid-dynamic aspects of reservoir modeling. with particular attention 
to physical properties that determine absolute and relative permeabilities and fluid movements. Phase changes and supercritical phenomena may play a role in these processes.

\section{J. Steam Quality Measurements}

While it should be relatively easy to develop techniques for characterizing steam quality at injection (e.g., by the use of multicolor infrared absorption measurements), the design of systems of this type for down-hole monitoring (e.g., through the use of fiber-optical systems) represents an interesting challenge. In general, a separate allocation is appropriate for DOE research funds to assist in the development of needed instrumentation.

\section{K. Oxygen-Enriched Thermal Recovery}

Work with oxygen-enriched air represents an obvious and important special case of studies with additives to achieve enhanced oil recovery.

\section{Advanced Concepts}

In a field as poorly understood, as empirically based, and as practically important as EOR, there must be room for innovation. The remaining total resource is sufficiently large to justify long-term studies without specified constraints other than that competent people should concentrate their research efforts to achieve improved recovery under environmentally acceptable conditions. 
1.2 Oil Recovery from the Tar Sands of Alberta

Oil recovery from the tar sands of Alberta has been practiced for some years on commercial scales. A review of activities on oil recovery from this enormously rich resource is therefore appropriate.

In 1967, Spragins ${ }^{2}$ ave the following estimates for the Athabasca deposits: $625 \times 10^{9} \mathrm{~B}$ with $285 \times 10^{9} \mathrm{~B}$ recoverable with "current" (1967) technology. The total Alberta deposits are now generally classified as containing about $1.4 \times 10^{12} \mathrm{~B}$ of which 25-30\% is considered to be recoverable with 1980 technology.

A Sun Company subsidiary, formerly called the Great Canadian $0 i 1$ Sands, Ltd. (GCOS) and now a division of Suncor, Inc., has been developing this area for some years. Investments amounted to $\$ 300 \times 10^{6}$ by 1973 , at which time a cumulative deficit of $\$ 90 \times 10^{6}$ had been incurred. ${ }^{3}$ The 1973 GCos (now suncor) production in an open pit mine amounted to $0.055 \times 10^{6}$ BPD and involved the use of $140,000 \mathrm{~T}$ of tar sands and removal of $130,000 \mathrm{~T}$ of overburden per day; at $100 \%$ recovery (actual recoveries are 60-75\%), these estimates correspond to an oil-to-sand weight ratio of about $7 \times 10^{-2}$. Production has been accomplished in a region where the ratio of overburden-to-tar-sands thickness is less than unity. The oil recovered contains bitumens, which are naturally occurring hydrocarbons. The overburden is scraped away to allow exposure of the bitumen-rich sands, which are then dug out with giant bucket-wheel excavators before removal on conveyor belts ${ }^{4}$ to

2 F. K. Spragins, "Mining at Athabasca - A New Approach to Oil Production," Journal of Petroleum Technology 19, 1337-1343 (1967).

${ }^{3}$ Various newspaper reports, December 1973.

4 E. D. Innes and J. V. D. Fear, "Canada's First Commercial Tar Sand Development" in Proceedings of the Seventh World Petroleum Congress, Volume 3 , pp. 633-650, Elsevier Publishing Co., New York, 1967. 
the bitumen recovery and upgrading plant. 4,5 While initial production favored regions of low overburden, about $5.0 \mathrm{~T}$ of Canadian tar sands and overburden must be handled on the average for each $B$ of oil produced. The producing area is covered by muskeg swamp (thick deposits of partially decayed vegetable matter of wet boreal regions), which is a semi-floating mass of decaying vegetation with sparse growth of tamarack or larch (a pine family with short fascicled deciduous leaves) and black spruce. Drainage networks are required for water removal and should ideally be installed two years before excavation begins. The low temperatures (to $-50^{\circ} \mathrm{F}$ ) encountered in the region produce extremely cohesive quartz-bitumen matrices, which are very difficult to penetrate and cause rapid deterioration of the excavator alloy cutting teeth. Even with the new and improved equipment that is now available, mining operations are curtailed at temperatures below about $-35^{\circ} \mathrm{F}$. During the summers, temperatures may rise to $90^{\circ} \mathrm{F}$ and the tar sands now become sticky with higher vapor pressures, but these features do not interfere significantly with current mining operations. Tar sands containing less than a critical amount of bitumen ( 6 to 8 weight percent) are rejected. The mean bitumen content of the tar sands (without overburden) for oil recovery in the GCOS operation ${ }^{3}$ is 12.4 weight percent.

The largest commercial tar sand project in Alberta is currently the Syncrude plant at Ft. McMurray. Site clearance began in December 1973 and the project went on stream in July 1978. Annual production reached around 125,000 BPD during 1980 and is projected to increase up to 160,000 BPD in 1982 . The total project cost was about $\$ 3.25 \times 10^{9}$ in 1977 dollars and the current owners are Imperial Oil (30\%), Cities Service (30\%) the Canadian federal government (15\%), Alberta (10\%), Gulf Canada (10\%), and

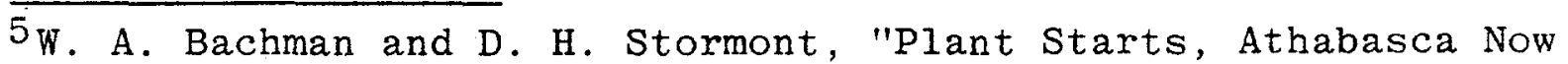
Yielding its Hydrocarbons," Oil and Gas Journal 65, 69-88, October 23, 1967. 
Ontario (5\%). The syncrude mine is one of the largest open-pit mines in the world. The oil-bearing silica sands are surrounded by films of water which, in turn, are surrounded by bitumen. The estimated life of the mine is 25 years (to 2003) and a total of about $1 \times 10^{9} \mathrm{~B}$ of oil is expected to be produced during this period. The syncrude plant area covers $5 \mathrm{~km}^{2}$, the open pit mine $25 \mathrm{~km}^{2}$, the tailing pond area $30 \mathrm{~km}^{2}$; the average muskeg depth is $3 \mathrm{~m}$, the overburden is $15 \mathrm{~m}$ thick, and the oil-sand depth is $42 \mathrm{~m}$. The peak-construction work force was 7500 , while the current work force on site is 3100 . One $\mathrm{m}^{3}$ of oil sand yields $1.4 \mathrm{~m}^{3}$ of sand and $0.22 \mathrm{~m}^{3}$ of bitumen from which $0.18 \mathrm{~m}^{3}$ of synthetic crude and $15 \mathrm{~m}^{3}$ of gas are recovered.

The mine is $4.2 \mathrm{~km}$ long, $7.5 \mathrm{~km}$ wide and $60 \mathrm{~m}$ deep. There are 4 draglines, the buckets hold $60 \mathrm{~m}^{3}$, the booms are $110 \mathrm{~m} 10 \mathrm{ng}$, and the draglines have a working radius of $104 \mathrm{~m}$. The overall weight of a dragline is $6100 \mathrm{mt}$ and the electric power use is $10 \mathrm{MW}_{\mathrm{e}}$. There are 4 bucket wheels in operation, each carrying 14 buckets with a capacity of $6400 \mathrm{mt} / \mathrm{hr}$; individual buckets carry $2 \mathrm{~m}^{3}$. Each bucket wheel uses $3.7 \mathrm{MW}$, weighs $2250 \mathrm{mt}$, and is $140 \mathrm{~m}$ long. Conveyor belts cover $17.7 \mathrm{~km}$ in the mine, $1.6 \mathrm{~km}$ in the plant, and they are $2.1 \mathrm{~m}$ wide and $3 \mathrm{~cm}$ thick.

The extraction plant processes $11,800 \mathrm{mt} / \mathrm{hr}$ of oil sand and produces $2050 \mathrm{mt} / \mathrm{hr}$ of bitumen-bearing froth. The frothtreatment plant produces $676 \mathrm{dm}^{3} / \mathrm{sec}$ of diluted bitumen.

The stack for upgrading facilities is $180 \mathrm{~m}$ high with a $20 \mathrm{~m}$ diameter at the base and an $8 \mathrm{~m}$ diameter at the top. There are 2 fluidcokers in use which are $63 \mathrm{~m} \mathrm{high}$.

The utility plant has an installed capacity of $260 \mathrm{MW}$ of which $185 \mathrm{MW}$ e represent the normal operating load; $1 \times 10^{6} \mathrm{~kg} / \mathrm{hr}$ of steam are produced. The water-treatment plant has a maximum flow of $850 \mathrm{~cm}^{3} / \mathrm{sec}$.

The product bitumens are stored in a $477,000 \mathrm{~m}^{3}$ tank, a $191,100 \mathrm{~m}^{3}$ tank is used for gas oil and a tank with a capacity of $83,500 \mathrm{~m}^{3}$ is used for naphtha. 
Shell Canada Ltd. filed an application in 1973 with the Alberta Energy Resources Conservation Board for bitumen recovery with the objective of $0.10 \times 10^{6} \mathrm{BPD}$ recovery by 1980 . In situ recovery operations for deeper-lying bitumen were tested by the Shell Oil Co. on 160,000 acres of leased land at Peace River (see Fig. 1.2-1), where 38 test wells to a depth of 1,800 feet had been drilled by the end of 1973. A prototype development plan called for a $\$ 30 \times 10^{6}$ program on 50 closely-spaced injection and production wells in 1974, with injection involving either steam, hot water, or light petroleum. This type of injectionrecovery scheme should be contrasted with partial-burning procedures. 6 It was anticipated that the porosity of the tar sands was sufficient to allow successful development of in situ recovery procedures. Current operations at peace River are described in Appendix $\mathrm{AB}-7$.

A number of other oil companies (Imperial, Amoco, a Japanese group, Mobil, Texaco, Chevron, Petro-Canada, Gulf, British Petroleum) are also experimenting with in situ recovery schemes. Many in situ projects are partly supported by the Alberta Oil Sands Technology and Reservoir Authority.

6. W. Camp, "The Tar Sands of Alberta, Canada," Cameron Engineers, Denver, Colorado, 1970. 


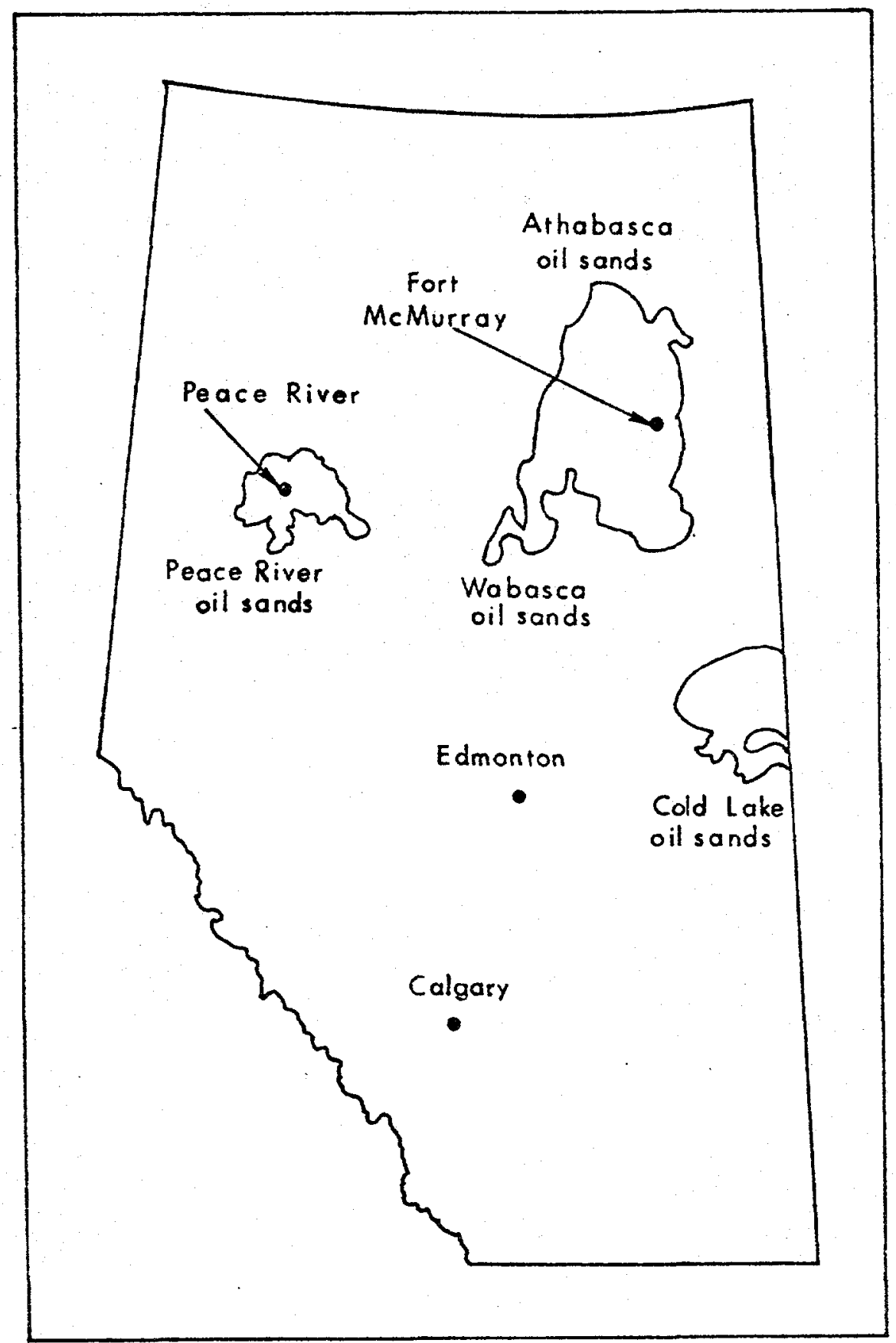

Fig. 1.2-1 Tar sand sites. The enclosed areas indicate the principal location of oil sands in the state of Alberta in Canada. 


\subsubsection{The GCOS (Suncor) Recovery and Upgrading Procedure of Oil from Tar Sands (Clark Process)}

The GCOS recovery process begins with excavation of bitumencontaining sands consisting, for example, of a mixture of 11,700 TPD of bitumens and 81,000 TPD of minerals [(1) in Fig. 1.2.1-1]. This mixture is introduced into a conditioning drum [2 in Fig. 1.2.1-1], together with caustic soda, water, and steam for reduction of sand-lump size. The smaller particles pass a vibrating screen [(3) in Fig. 1.2.1-1], while oversize particles are discarded. Hore water is added to the particles passing the screen prior to introduction into a three-layer separation cell [(4) in Fig.1.2.1-1]. The bitumen floats to the top of the separation cell and is largely recovered in this top-layer froth [(4) in Fig.1.2.1-1], while sand is discarded at the bottom and the middlings of intermediate density are partly returned to the separator for recycling and partly forwarded to a scavenger separation cell [(5) in Fig. 1.2.1-1] for separate treatment in a froth settler [(6) in Fig. 1.2.1-1]. The top-froth layers from the separation cell [(4) in Fig.1.2.1-1] and the froth settler [6] in Fig.1.2.1-1] are mixed with naphtha before introduction for upgrading in centrifuges [(7) in Fig.1.2.1-1], from which tailings (bitumen-to-minerals weight ratio $\simeq 0.21$ ) and upgraded feed (bitumen-to-minerals weight ratio $\simeq 51$ ) for the coker are supplied; about $87 \%$ of the feed bitumen enters the coker. This feed bitumen is an $8^{\circ}$ API oil containing $4 \%$ of sulfur.

The GCOS upgrading process for the tar-sand bitumens is shown schematically in Fig.1.2.1-2 and is reproduced from Roberts. 7 The total mined tar sand input is $0.105 \times 10^{6}$ TPD corresponds to $0.065 \times 10^{6} \mathrm{BPD}$ and produces $0.050 \times 10^{6} \mathrm{BPD}$ of syncrude ( $77 \%$ conversion), as well as $2.58 \times 10^{3}$ TPD of coke and 350 TPD of sulfur. The flow diagram shown in Fig.1.2.1-2 is self-explanatory. The overall hydrogen consumption is about 1000 SCF per $B$ of

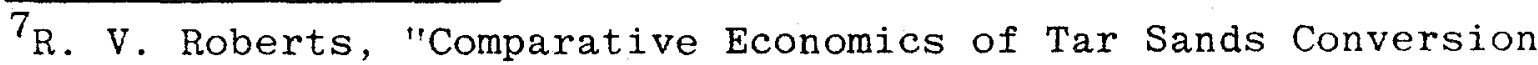
Processes," Stanford Research Institute, Menlo Park, California, 1970 .
} 


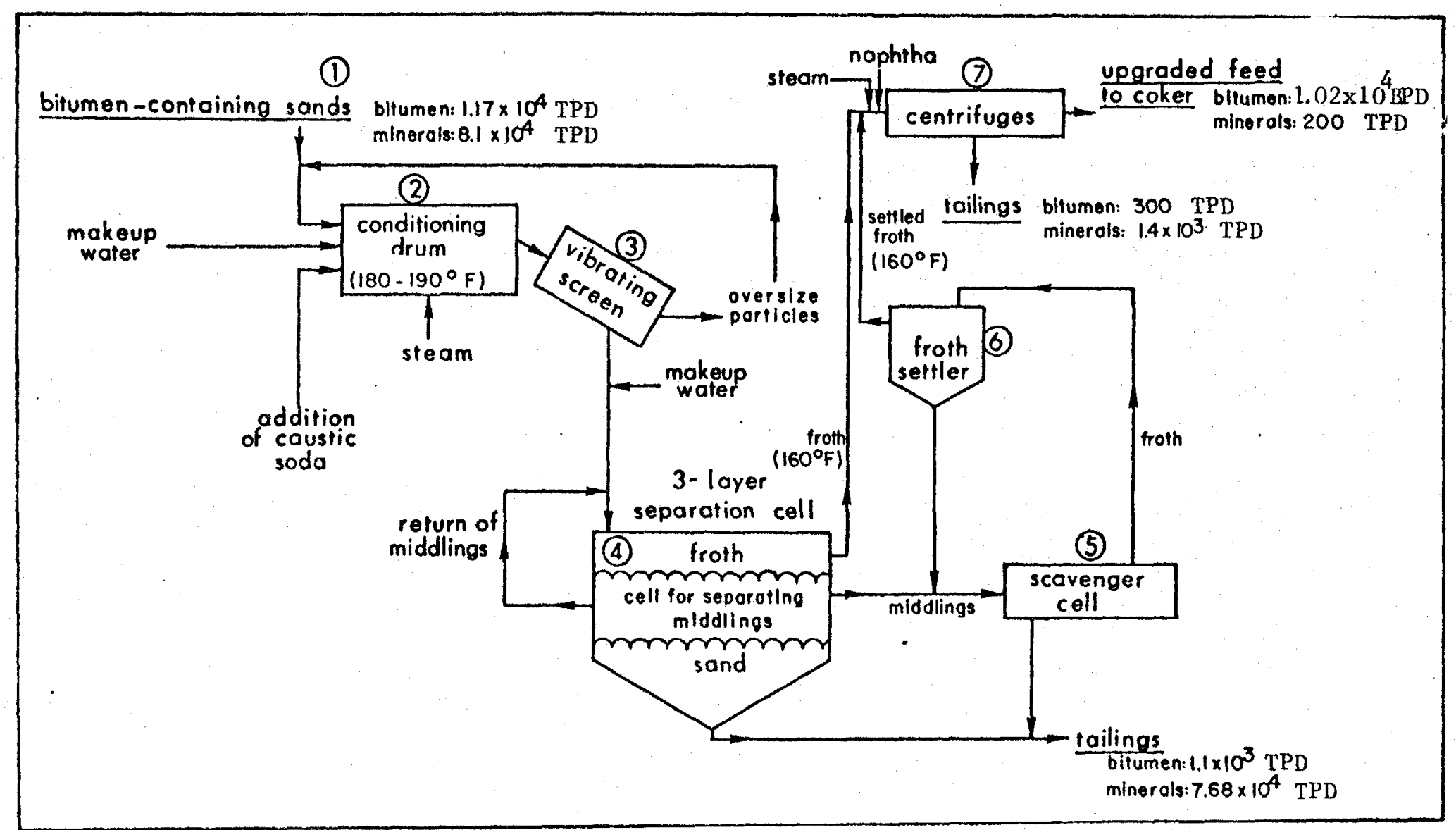

Fig. 1.2.1-1 The bitumen recovery scheme pioneered by GCOS and used by suncor and Syncrude. 7 


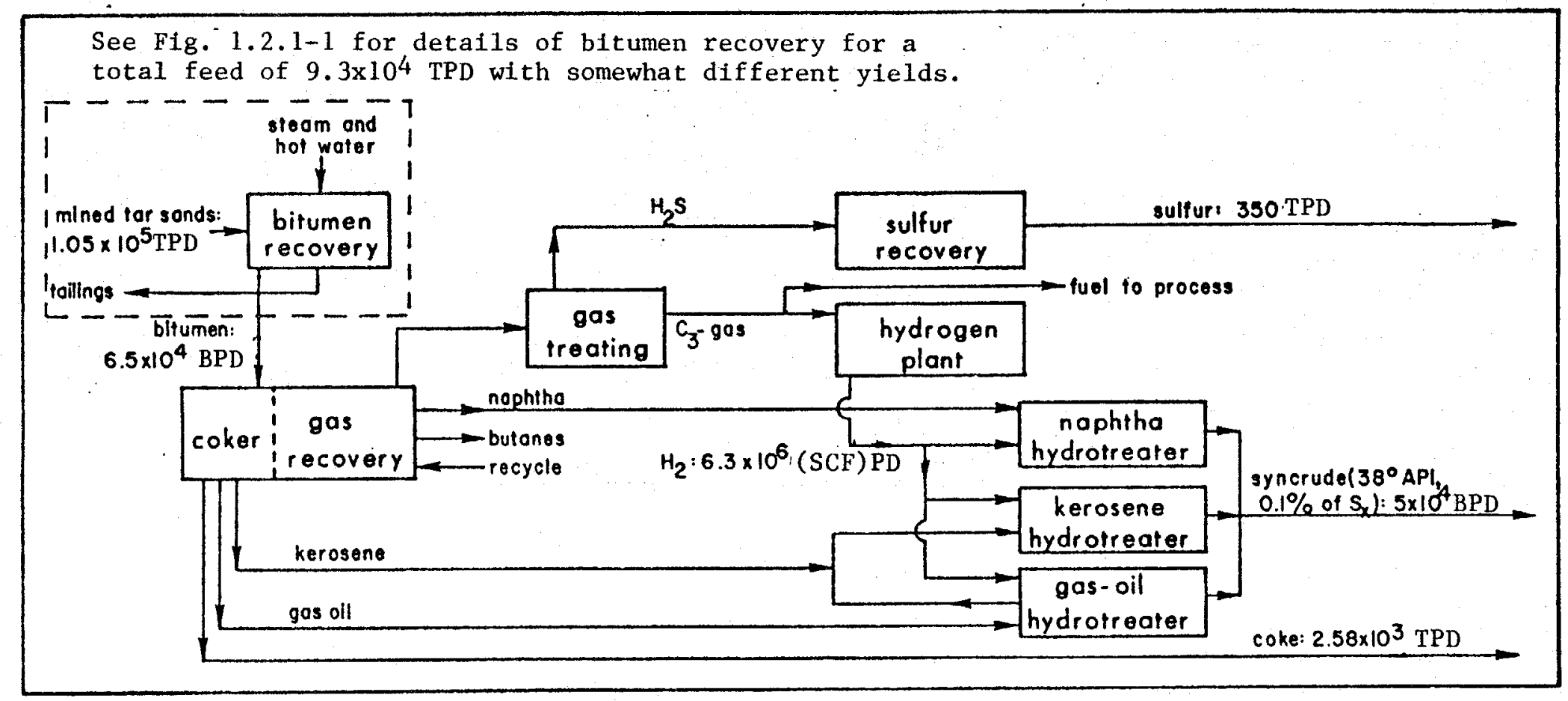

Fig. 1.2.1-2 The GCOS upgrading process for bitumen recovered from tar sands; reproduced with modifications from Ref. 7 . 
high-quality syncrude containing less than $0.1 \%$ of $\mathrm{S}_{\mathrm{x}}$.

\subsubsection{The Syncrude Recovery and Upgrading Procedure of Oil from Tar Sands}

The syncrude recovery process is also a version of the clark process; the upgrading procedure involves fluid coking of bitumen in such a manner that the released gases contain appreciable amounts of $\mathrm{H}_{2} \mathrm{~S}$. The resulting liquid product is a mixture of butanes, oil residue, and intermediate fractions containing naphtha and light and heavy gases, which are further hydrotreated catalytically. The syncrude-to-bitumen recovery ratio is raised to $87 \%$ but with somewhat higher sulfur content than the GCOS syncrude.

Details concerning current Syncrude operations are described in Appendix $\mathrm{AB}-7$.

1.3 Oil Recovery from the Tar Sands of Utah*

\subsubsection{Introduction}

The United States has large deposits of heavy oils which resemble heavy petroleum residues, as well as tar sands with hydrocarbons known as bitumens that are generally more viscous than petroleum resids and black oils. The resource base of black oil and tar sands in the U.S.A. way be as high as $10^{11} \mathrm{~B}$ in place. A definition regarding what a tar sand is has not yet been acceptably established by the scientific and engineering communities, but the D.O.E. has recently proposed that a tar sand deposit is a deposit containing bitumen with a viscosity in excess of $10,000 \mathrm{cp}$ at reservoir temperature.

The U.S. deposits of tar sands have been estimated to be about $36 \times 10^{9} \mathrm{~B}$ in place (Table 1.3.1-1). Examination of Table 1.3.1-1 shows that most of these tar sands are in Utah (Fig.1.3.1-1).

\footnotetext{
* An overview of U.S. tar sands resources and recovery projects has been prepared by L. C. Marchant and C. A. Koch and is reproduced in Appendix AB-8.
} 
Table 1.3.1-1 Deposits of bitumen-bearing rocks in the United States with resources over 1 × $10^{6} \mathrm{~B}$; prepared by workers at the Laramie Energy Technology Center of the Department of Energy.

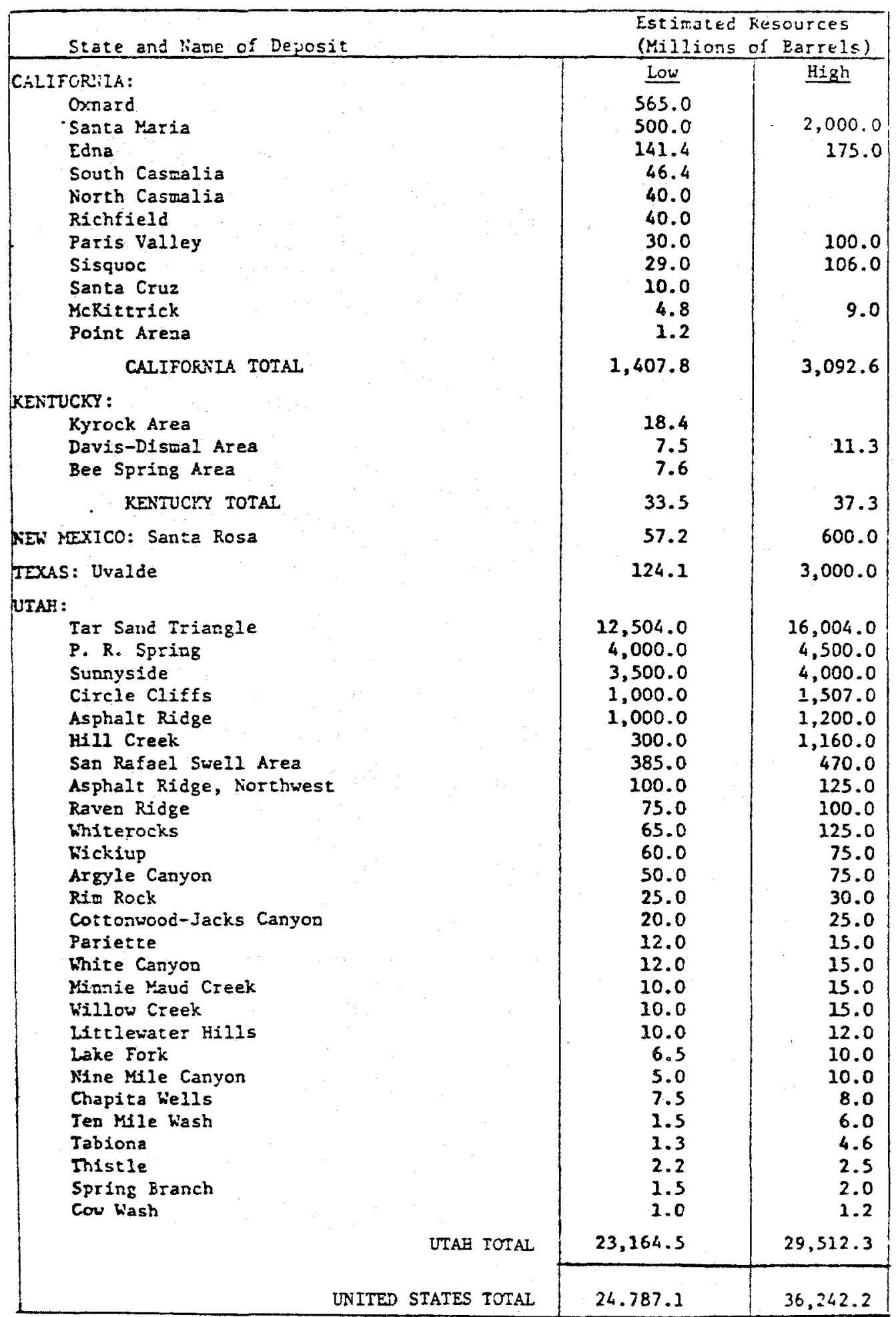




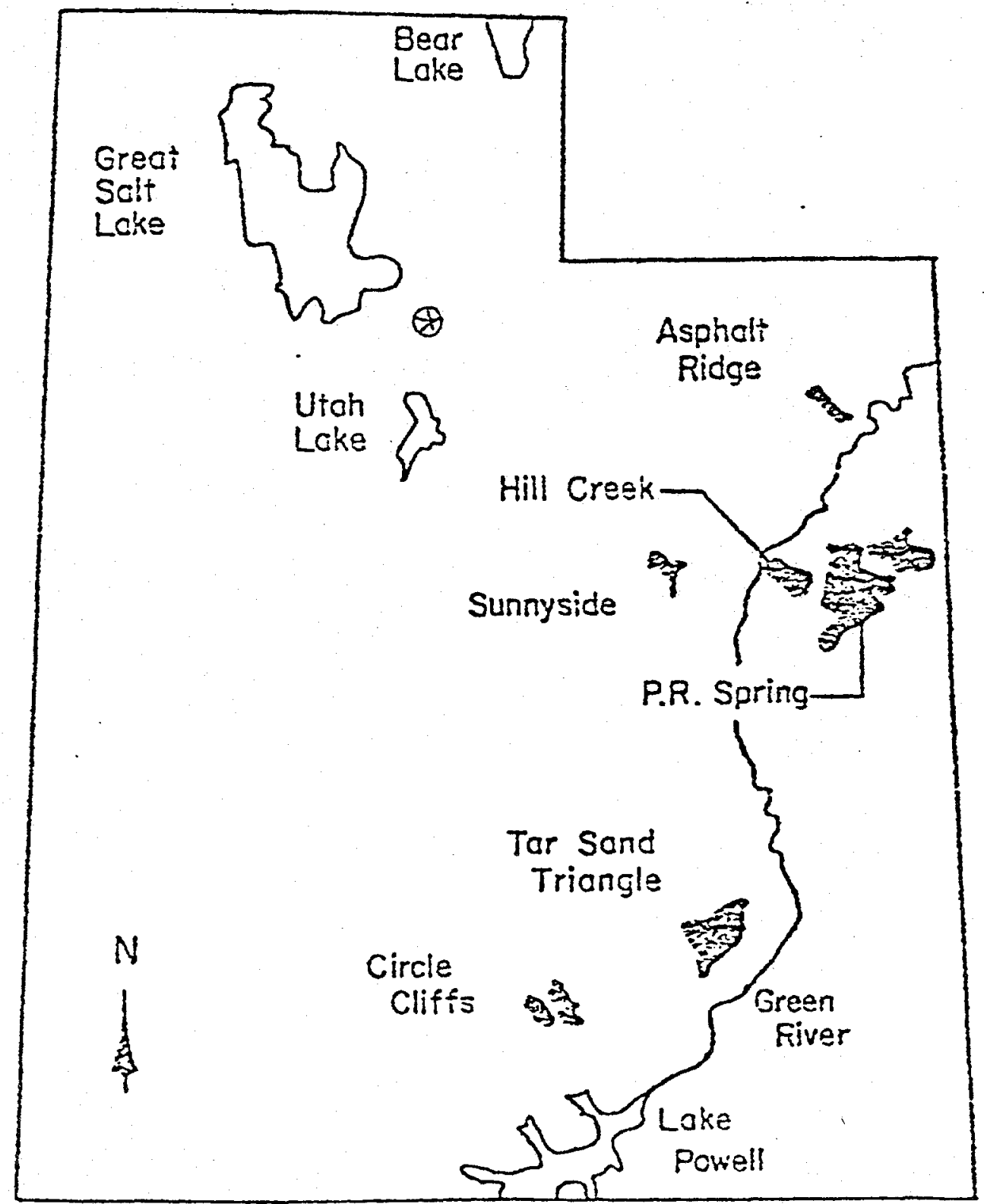

Fig. 1.3.1-1 Major tar sand deposits in the State of Utah. 
The work of Ritzma and his associates at the Utah Geological and Mineral Survey in defining these deposits has been responsible for generating much of the present interest in Utah tar sands. ${ }^{8}$ More recent studies on Utah tar sands have been performed by Kuuskraa et al 9 and by workers at Enercor. ${ }^{10}$ Definitions and characterizations of U.S. tar sands as a resource are still incomplete and much more must be done before commercialization can begin. Reliable estimates of resources suitable for commercial exploitation, either by in situ recovery procedures or by mining and bitumen recovery involving processes similar to those used in Canada or other technologies, are not generally available.

A survey of the literature on technology relating to bitumen recovery from U.S. tar sands in the early 1970s, using in situ methods or mining and aboveground processing, showed that little information was available. The literature on Canadian tar sands is, however, extensive. Workers at the U.S. Bureau of Mines had performed bench scale work on water extraction in 1948 . There have been several attempts at pilot operations in the field for both in situ and aboveground processing. Backyard inventors have been active in extructing oil from Utah tar sands for many years, mainly by solvent extraction, but none of these processes has led to significant commercial activity. This situation began to change during the middle 1970s when larger scale work began at LETC on in situ recovery and at the University of Utah on aboveground processing of tar sands. Recently, groups in private industry have become active in developing technology for processing Utah tar sands.

8 H. R. Ritzma, "Commercial Aspects of Utah's Oil-Impregnated Sandstone Deposits," paper presented to Interstate Oil Compact. Comm., New Orleans, December 3, 1973.

9 V. A. Kuuskraa, S. Chalton, and T. M. Doscher, "The Economic Potential of Domestic Tar Sands," D.O.E. Report \#HCP/T9014-01, U.S.C. -91 , Los Angeles, California, January 1978 .

private communication from Enercor, Inc, $57 \mathrm{~W}$ 2nd South, Salt Lake City, Utah, 1981. 


\subsubsection{The Utah Resource Base}

Estimates of in place bitumens for Utah tar sands are given in Table 1.3.2-1. These estimates are based on Ritzma's data. 8 The bitumen contents shown are based on data of Wood and Ritzma. ${ }^{11}$ The bitumen contents in any deposit vary widely from point to point within the deposit and much more work is required to substantiate these estimates.

Recent estimates at Enercor ${ }^{10}$ of material recoverable by mining and aboveground processing are shown in Table 1.3.2-2. Previous estimates in Ref. 9 were much lower than those shown in Table 1.3.2-2. The following criteria were used in Ref. 9 to define tar-sand deposits suitable for mining and aboveground processing: $8 \%$ or higher bitumen content (grade); overburden-to-ore ratio= 0.4 for the Tar Sand Triangle, P. R. Spring, Sunnyside, and Hill Creek deposits and 1.0 for Asphalt Ridge. When these requirements were combined with a minimum overburden of $350 \mathrm{ft}$ for in situ recovery, the following estimates were obtained: 100-200 $\mathrm{x} 10^{6} \mathrm{~B}$ are suitable for mining at Asphalt Ridge (no suitable deposits were found elsewhere on the basis of available core data) and possibly as much as $2.0 \times 10^{9} \mathrm{~B}$ are technically and economically feasible for recovery by using in situ techniques from the Tar Sand Triangle $\left(1.5 \times 10^{9}\right.$ B) and Sunnyside $\left(0.5 \times 10^{9} \mathrm{~B}\right)$.

\subsubsection{Chemical Analyses of Utah Tar Sands}

Utah tar-sand bitumens may be classified into two general groups. Those in the Uinta Basin are believed to be of lacustrine origin and those of south central Utah are thought to be

${ }_{11}$ R. E. Wood and H. R. Ritzma, Special Study 39 , Utah Geological and Mineralogical Survey and University of Utah, Salt Lake City, January 1972 . 
Table 1.3.2-1 Tar-sand deposits in Utah; from Ref. 11.

\begin{tabular}{|l|c|c|}
\hline \multicolumn{1}{|c|}{ Deposit } & $\begin{array}{c}\text { Bitumen in Place } \\
\left(10^{9} \mathrm{~B}\right)\end{array}$ & $\begin{array}{c}\text { Bitumen Content } \\
(\text { wt. \% })\end{array}$ \\
\hline Tar Sand Triangle & $12.4-16.0$ & $5-8$ \\
P. R. Spring & $4.0-4.5$ & $6.5-14$ \\
Sunnyside & $3.5-4.0$ & $8-9$ \\
Hill Creek & 1.2 & $6-7$ \\
Circle Cliff & 1.3 & $8-14$ \\
Asphalt Ridge & 1.15 & $4-7$ \\
White Rocks & $0.6-1.25$ & 7 \\
\hline
\end{tabular}


Table 1.3.2-2 Estimates of mineable tar sands assuming 3 cubic yards of overburden per B; reproduced from Ref. 11.

\begin{tabular}{|l|c|}
\hline Deposit & B Recoverable \\
\hline \hline Asphalt Ridge & $150 \times 10^{6}$ \\
White Rocks & $100 \times 10^{6}$ \\
P. R. Spring & $1.5 \times 10^{9}$ \\
Sunnyside & $2.0 \times 10^{9}$ \\
\hline
\end{tabular}


of marine origin. Uinta Basin bitumens are low in sulfur and aromatic content while those in the Tar Sand Triangle area have similar properties to Athabasca bitumens and also have similar sulfur and aromatic contents (Table 1.3.3-1). Generally, the Utah bitumens are one to four times more viscous than Athabasca bitumens (Fig. 1.3.3-1). Estimates of the bitumen content of the Utah tar sands vary from 4 to $14 \%$ (see Table 1.3.2-1). As with the Athabasca deposits, the grade varies within the deposits. More thorough definition is needed to firm up these rough estimates of grade, which are derived from outcrops and analyses of available core samples.

The mineral part of the Utah tar sands is largely quartz (beach sand) with some small amounts of other minerals. Figure 1.3.3-2 shows particle size distributions for various sands in Utah. The mineral matter in Utah sands contains very little, if any, clay material, as opposed to the Athabasca sands which contain as much as $8 \%$ finely divided clay minerals, some of which exhibit swelling in water. The clay minerals contribute to the formation of sludge in the clark hot water process employed in Alberta and make the large settling ponds necessary for disposal of tailings. Large tailing ponds that are maintained for many years will probably not be needed in processing Utah tar sands.

Another occasional difference between Utah tar sands and those at Athabasca is the water content of the freshly mined sand. Some of the Utah tar sands are dry and contain less than 0.5 wt.\% of connate water while others are similar to Athabasca tar sands and contain 3-5 wt.\% or more. This difference makes for important processing differences, as will be discussed in the following sections.

\subsubsection{Recovery Technology}

There are two basic technologies used for the recovery of oil from tar sands. These are: (i) mining and aboveground processing with (a) hot-water recovery, (b) solvent 
Table 1.3.3-1 Typical bitumen properties for general groups of tarsands deposits.

\begin{tabular}{|c|c|c|}
\hline Properties & $\begin{array}{c}\text { Group 1: Asphalt } \\
\text { Ridge, Sunnyside } \\
\text { and P. R. Spring, } \\
\text { Utah }\end{array}$ & $\begin{array}{l}\text { Group 2: Tar Sand } \\
\text { Triangle, Utah, and } \\
\text { Athabasca, Canada }\end{array}$ \\
\hline Carbon weight \% & 85 & 83 \\
\hline Hydrogen & 11.4 & 10.3 \\
\hline Nitrogen & 1.0 & 0.5 \\
\hline Sulfur & 0.5 & 4.7 \\
\hline Oxygen & Variable & Variable \\
\hline $\mathrm{C} / \mathrm{H}$ atomic ratio & $0.60-0.65$ & $0.65-0.70$ \\
\hline Vanadium ( $\mathrm{ppm})$ & 25 & $100-300$ \\
\hline Nickel (ppm) & 120 & $50-100$ \\
\hline $\begin{array}{l}\text { Viscosity at } 77^{\circ} \mathrm{F} \\
\left(0.05 \text { sec }^{-1}, \text { poise }\right)\end{array}$ & $3-30 \times 10^{4}$ & $0.4-1.5 \times 10^{4}$ \\
\hline $\begin{array}{l}\text { Penetration } 1 / 10 \mathrm{~mm} \text {, } \\
50 \mathrm{~g}, 5 \mathrm{sec}\end{array}$ & $<300$ & $<300$ \\
\hline Specific gravity & 0.985 & 1.00 \\
\hline API gravity, degrees & 12.0 & 10 \\
\hline $\begin{array}{l}\text { Carbon residue } \\
\text { (Rammsbottom) }\end{array}$ & $3-12$ & $10-22$ \\
\hline Asphaltenes (pentane) & $4-16$ & $16-26$ \\
\hline Avg. M.W. (VPO-benzene) & $660-800$ & $540-600$ \\
\hline Heating value (Btu/lb) & 18,500 & 17,800 \\
\hline o volatiles at $530^{\circ} \mathrm{C}$ TBP & 50 & 60 \\
\hline
\end{tabular}




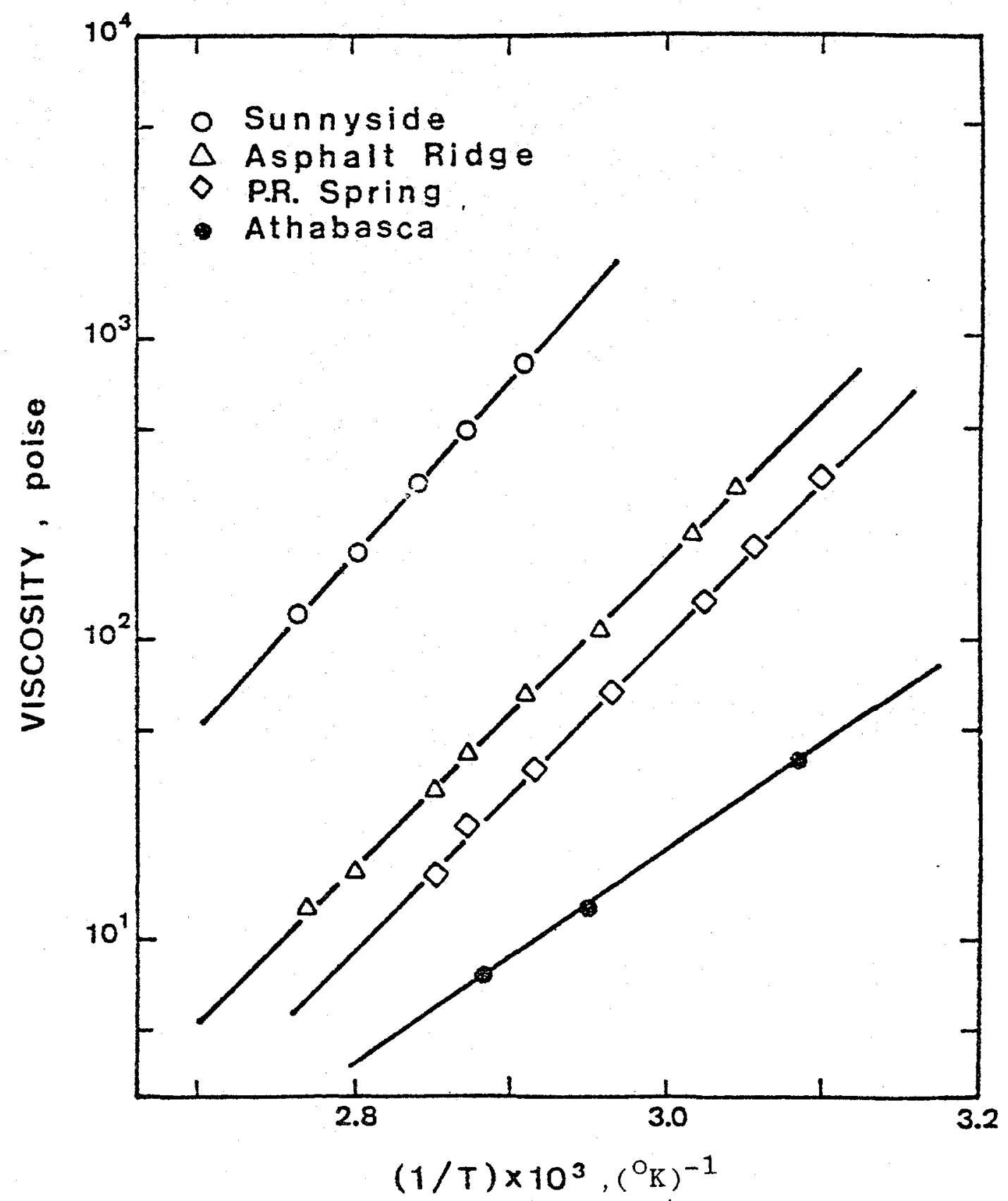

Fig. 1.3.3-1 Arrhenius-type plot illustrating the effect of temperature on viscosity for bitumens from various Utah and from Athabasca tar sand deposits. 


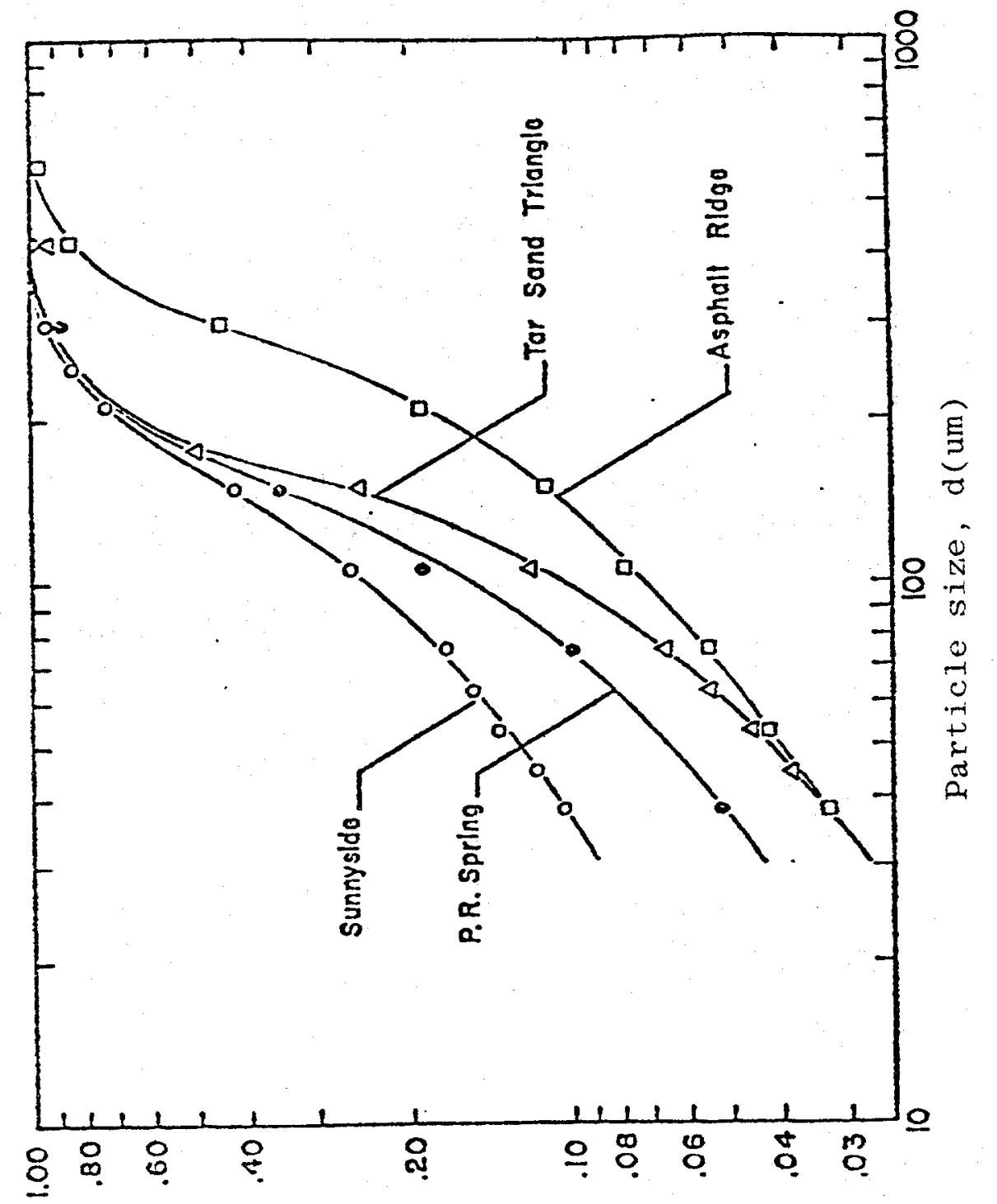

灾

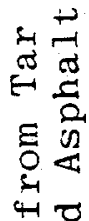

U

范

us

疍

D

วิ

Tr

Ð0

的政

$\tau$.

$0^{2}$

N.

沿莒

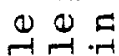

O bo

$\rightarrow$ ते

t.

त. द्व

DE地

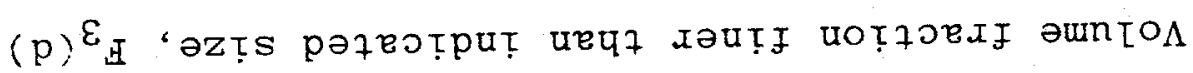

0
1
0
$n$
-1
-1
-1
0 
extraction, or (c) thermal recovery; (ii) in situ processing with (a) thermal methods with partial combustion or (b) steam injection.

Since 1973-74, A. G. Oblad et al (with federal funding) at the University of Utah have studied most of these alternatives and selected to concentrate on mining and aboveground processing. Study of the three recovery alternatives for aboveground processing indicated that the best prospects were hot water processing and thermal recovery. In the latter, a promising alternative appeared to be the use of fluid-bed technologies similar to the procedures applied in the petroleum industry for catalytic cracking. The in situ work has been continued at the Laramie Energy Technology Center.

\subsubsection{Hot-Water Recovery Process}

The University of Utah process takes into account the differences between Athabasca and Utah tar sands, i.e., the much higher viscosity of the Utah bitumens and the absence of a water film coating the sand between the oil and the sand surface. The process involves a digestion of the sand in hot water under high shear conditions, adjustment of the reaction $\mathrm{pH}$ with alkali, and final separation by a modified flotation technique. The main variables in the digestion step are temperature, $\mathrm{H}_{2} \mathrm{O} /$ sand weight ratio, $\mathrm{pH}$, degree of agitation, time, viscosity of the bitumen, and grade of the tar sand. The main variables in the floatation step are temperature, time and rate of air injection.

A process has been developed in which the variables have been optimized. Laboratory recoveries in the 95\% range have been achieved consistently with both high and low grade materials, including the P. R. Spring, Asphalt Ridge, Sunnyside, and White Rocks deposits in Utah. Good results have also been obtained with low grade tar sands of Kentucky. The oil contents of the concentrate vary from 30 to $75 \%$, depending on tar-sand grade, viscosity 
of the bitumen and sand particle-size distribution. Methods have been developed for upgrading the concentrate to $98 \mathrm{wt} . \%$ bitumen or better.

\subsubsection{Fluid Bed Thermal Recovery}

Heating of tar sands to temperatures as high as $500^{\circ} \mathrm{C}$ leads to vaporization and cracking of the bitumen content. Gaseous and vaporized yields of liquids are typical of those achieved in coking a heavy petroleum residuum. Coke produced remains with the sand. The coked sand can be burned cleanly by using air at $500^{\circ} \mathrm{C}$ and higher. A substantial effort has been made by various workers at Utah to translate these findings into successful processes. No commercial operations are as yet in existence.

After considering a range of possibilities for thermal recovery (including the use of Lurgi reactors, rotary kilns and fluid beds), fluid bed reactors were chosen. It was observed early in the program that cleanly burning tar sands can be readily fluidized. Hence, a study of this system was carried out. The effects of temperature, retention time and sand particle-size distribution on the recovery of syncrude were studied. The results showed that recoveries of liquid products in excess of $70 \mathrm{wt} . \%$ and perhaps as high as $80 \mathrm{wt} . \%$ are possible, with coke and gas makes of 15-20 wt.\% and 10-20 wt.\%, respectively. Properties of the synthetic crudes vary widely, depending on the properties of the bitumen contained in the sand, temperature of reaction and retention time. The crudes are similar to heavy crude oils and are in the $15-25^{\circ} \mathrm{API}$ range.

AII thermal routes for oil recovery require much energy, which may be obtained by burning the coke from the sand. Theoretically, there is more than enough energy released in this step to provide the heat needed for the coking step. With this in mind, an integrated process scheme has been designed, which involves coking and 
burning of the sand in separate steps and transfer of heat from burning to coking by recycle of burned sand. This sequence is similar to catalytic cracking and is shown schematically in Fig. $1.3 .6-1$.

Analysis of such a scheme by computer modeling shows that the most promising version is one of upgrading the bitumen grade to 25-40\% and using this concentrate as feed to the thermal system. This step, which can be carried out readily with hot water recovery or by ambient temperature techniques now under development at the University of Utah, removes as much as $75 \%$ of the sand, which then does not need to be handled further. Thus, the thermal equipment can be greatly reduced in size, the recycle ratio (hot sand/feed) can be brought to a reasonable level, and the sand burning temperature can be limited.

\subsubsection{Upgrading of the Recovered Bitumens}

The bitumens from Utah tar sands have been characterized and subjected to the techniques used in the U.S. petroleum industry for upgrading heavy petroleum fractions. Visbreaking, thermal cracking, coking, catalytic cracking, hydrotreating, and hydropyrolysis (a new technique) have been employed. Coking, catalytic cracking and hydropyrolysis appear to be promising routes for upgrading (see Table 1.3.7-1). The important conclusion derived from these investigations is that high grade, synthetic crudes similar to those made commercially in Canada can be obtained from Utah tar sands. The design of the optimal processing scheme will require thorough economic analysis for elucidation.

\subsubsection{Pilot Plant Studies}

Many important pilot plants are currently being tested, including a pilot plant to test the University of Utah hot water recovery process which has been constructed near the Chevron Refinery 


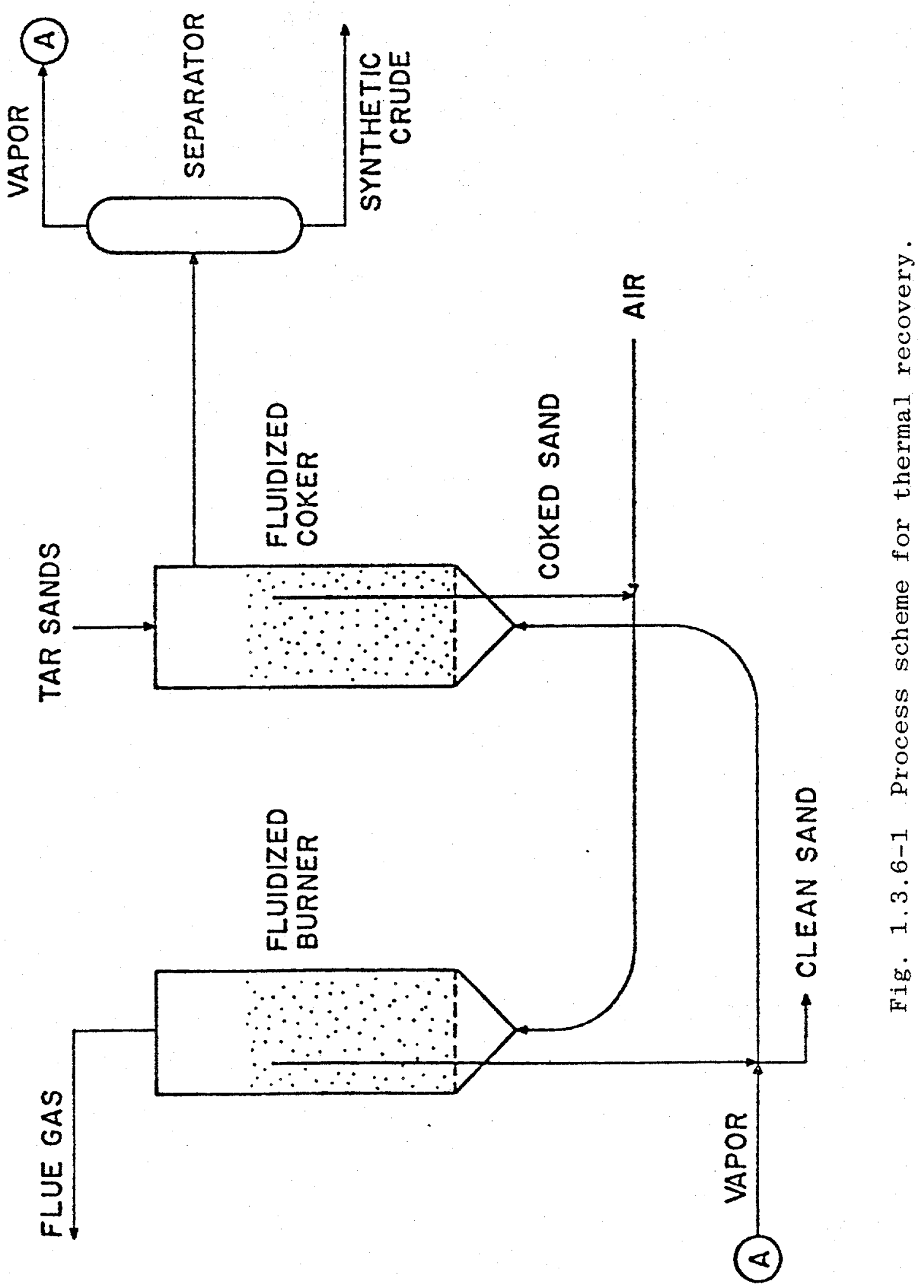


Table 1.3.7-1 Comparison of yield and conversion results for the primary processing of Asphalt Ridge bitumen; conversion is defined as the percentage of material boiling above $538^{\circ} \mathrm{C}$ that is converted to material boiling below $538^{\circ} \mathrm{C}$.

\begin{tabular}{|c|c|c|c|c|c|}
\hline \multirow[b]{2}{*}{ Process } & \multicolumn{3}{|c|}{ Yield of } & \multirow[b]{2}{*}{$\begin{array}{c}\% \text { Liquids } \\
\text { distillable }\end{array}$} & \multirow[b]{2}{*}{ Conversion } \\
\hline & Gases & Liquids & $\begin{array}{l}\text { Total gases } \\
\text { and } 1 \text { iquids } \\
\text { in wt.\% }\end{array}$ & & \\
\hline Visbreaking (VB) & 1 & 99 & 100 & 67 & 46 \\
\hline Coking $\mathrm{TC}(80)$ & 7 & 70 & 77 & 100 & 62 \\
\hline Catalytic cracking (CC) & 10 & 74 & 84 & 99 & 72 \\
\hline Coking TC(0) & 4 & 83 & 87 & 97 & 74 \\
\hline Hydropyrolysis (HP) & 27 & 73 & 100 & 85 & 82 \\
\hline
\end{tabular}


in North Salt Lake City. The plant is producing a concentrate which can be upgraded, The upgrading will not be done at the pilot plant, but the product bitumen will be tested elsewhere. Technology for upgrading by coking is already available. Upgrading by catalytic cracking or by hydropyrolysis will have to be tested at a pilot plant scale before these technologies can be commercialized. A flow sheet for the pilot plant is shown in Fig. 1.3.8-1.

\section{3 .9 In Situ Recovery}

Workers at the Laramie Energy Technology Center have carried out three in situ tests at Asphalt Ridge since 1975. The site selected for these tests is located at the north end of the deposits. Two of these tests involved reverse combustion and a more recent third test was carried out using steam injection. The combustion tests were done on a 12-ft seam of sand,which is 350-450 ft below the surface; the steam flood tests were done on a 45-50 ft seam at a depth of $550 \mathrm{ft}$. In the second test employing reverse combustion, up to $25 \%$ of the bitumen values were recovered as upgraded oil. About $50 \%$ of the air injected was accounted for in the recovered gases. The steam flood was similar in concept to those being used in Alberta at Peace River and Cold Lake. Steam was injected at 360-530 psig. Total production during 160 days of operation was $1,150 \mathrm{~B}$ of oil and 6,250 B of water. The total steam injected was equivalent to $65,700 \mathrm{~B}$ of water.

\subsubsection{Economics of Bitumen Recovery from Utah Tar Sands}

A recent economic assessment (based on sma11-scale laboratory studies) of a 2000 BPD demonstration plant for producing synthetic crude oil from Utah tar sands was made available by Enercor (cf. Appendix $A B-1$ ) and involves mining, hot-water extraction and 


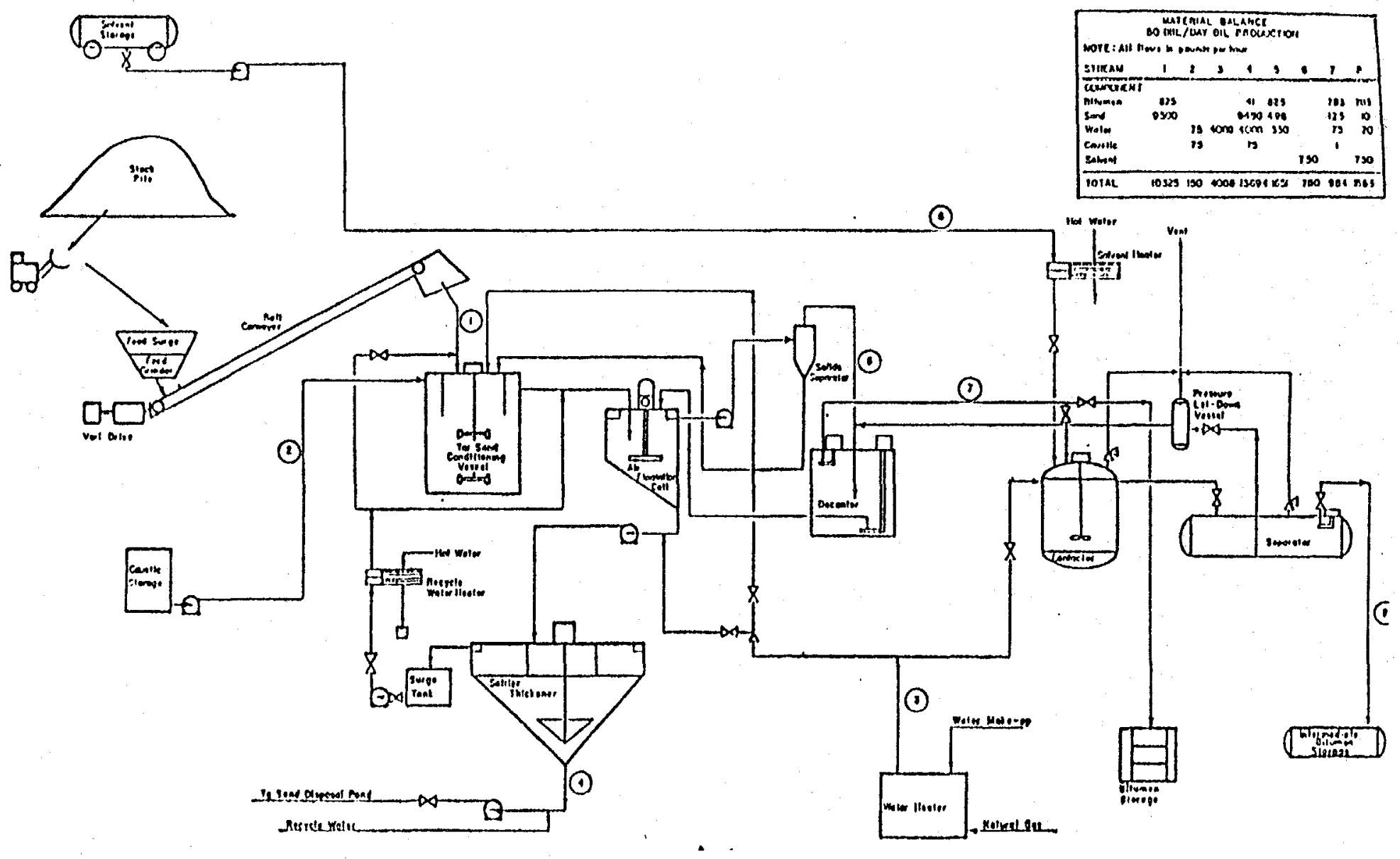

Fig. 1.3.8-1 pilot plant for bitumen recovery by the University of Utah hot-water process. 
Table 1.3.10-1 Summary of projected capital and operating costs $(660,000$ BPY).

\begin{tabular}{|c|c|c|c|}
\hline \multicolumn{4}{|c|}{ Capital Costs in $\$ 10^{3}$} \\
\hline \multicolumn{2}{|l|}{ Mine development } & \multicolumn{2}{|c|}{3,980} \\
\hline \multicolumn{2}{|l|}{ Permits and project direction } & \multicolumn{2}{|r|}{300} \\
\hline \multicolumn{2}{|l|}{ Engineering } & \multicolumn{2}{|r|}{1,500} \\
\hline \multicolumn{2}{|c|}{ Processing plant and materials handling } & \multicolumn{2}{|c|}{12,648} \\
\hline \multicolumn{2}{|l|}{ Offsites } & \multicolumn{2}{|c|}{1,638} \\
\hline \multicolumn{2}{|l|}{ Subtotal } & \multicolumn{2}{|c|}{20,066} \\
\hline \multicolumn{2}{|l|}{ Contingency of $20 \%$} & \multicolumn{2}{|c|}{4,013} \\
\hline \multicolumn{2}{|l|}{ Total } & \multicolumn{2}{|c|}{24,079} \\
\hline \multicolumn{4}{|c|}{ Operating and Product Costs } \\
\hline & \multirow{2}{*}{\multicolumn{2}{|c|}{$\frac{\begin{array}{c}\text { Annual Opera- } \\
\text { ting Costs, } \$ 10^{3}\end{array}}{1,787}$}} & \multirow{2}{*}{$\frac{\begin{array}{c}\text { Product } \\
\text { Cost } \$ / \mathrm{bb} 1\end{array}}{2.71}$} \\
\hline Plant labor & & & \\
\hline Labor, fringe benefits & \multicolumn{2}{|l|}{518} & 0.78 \\
\hline Maintenance materials & \multicolumn{2}{|l|}{565} & 0.85 \\
\hline Utilities & \multicolumn{2}{|l|}{2,366} & 3.59 \\
\hline Chemicals & \multicolumn{2}{|l|}{169} & 0.26 \\
\hline Taxes and insurance & \multicolumn{2}{|l|}{339} & 0.51 \\
\hline Royalties & \multicolumn{2}{|l|}{2,838} & 4.30 \\
\hline General administration & \multicolumn{2}{|l|}{355} & 0.54 \\
\hline $\begin{array}{l}\text { Mining costs }(1,850,000 \text { TPY }) \\
\text { at } \$ 3.64 / \text { ton }\end{array}$ & \multicolumn{2}{|l|}{6,654} & 10.08 \\
\hline $\begin{array}{l}\text { Contingency, } 10 \% \text { of non-mining } \\
\text { costs }\end{array}$ & \multicolumn{2}{|l|}{894} & 1.35 \\
\hline Total Cost & \multicolumn{2}{|l|}{16,485} & 24.97 \\
\hline
\end{tabular}


coking of the clean bitumen. The site for the operation is State Lands at a Northeast P. R. Spring site. The tar sand at that site is in a 24 foot thick seam with an average bitumen content of $8 \%$. The average overburden is 0.92 ton per ton of tar sand and recovery was set at $75 \%$ liquid yield by volume. The data are presented in Table 1.3.10-1. No depreciation costs are shown nor are profitability estimates made. Depreciation will depend on what is done with the plant after the demonstration is completed. The sale price of the products, which will include coke and syncrude produced in the coker, has not yet been established on a firm basis.

\subsubsection{Environmental Aspects of Tar Sand Development}

The environmental issues that will have to be addressed in tar-sand development are as follows:

i. Requirements for auxiliary energy sources and for water and other renewable resources.

ii. Maintenance of local and regional air quality.

iii. Maintenance of $l o c a l$ and regional water quality and supplies.

iv. Land disturbances and reclamation or reconstruction.

v. Preservation of archeological and historical sites.

vi. Survival and health of terrestrial and aquatic ecosystems.

vii. Population growth and socioeconomic impacts of a large developing industry.

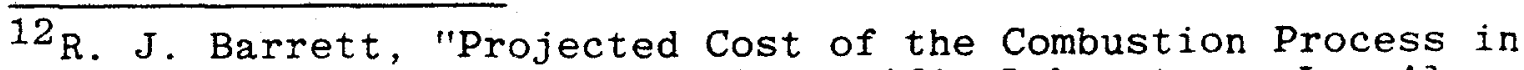
Utah Tar Sand," Los Alamos Scientific Laboratory, Los Alamos, New Mexico, paper presented at a Meeting of the Interstate Oil Compact. Comm., Vail, Colorado, June 1980. 
It is expected that the development of Utah tar sands will have modest environmental effects. Studies are currently being carried out to assess these effects at LETC and by the BLM and private industry. Water use is expected to be in the range of $2-4 \mathrm{~B} / \mathrm{B}$ of bitumen produced.

The main environmental impacts will involve land disturbances and air pollution in the case of mining and aboveground processing. As we have already noted, the large tailing ponds required in Canada are not expected to be required for Utah tar sands because of high bitumen recoveries and the very low clay contents of the sands. These two factors are the principal causes of the sludge produced in Athabasca tar-sand processing and make the very large tailings ponds necessary. For in situ recovery, the main impacts will involve air pollution and, possibly, long-range modifications of regional hydrology. 
1.4 Research Recommendations on Oil Recovery from Tär Sands Derived from Site Visits and Discussions

Site visits and dicussions involving FERWG members are summarized in Appendix B. In connection with these activities, $R \& D$ needs were repeatedly discussed. A compilation of research recommendations derived from these activities is given in Table 1.4-1. The topics identified in Table 1.4-1 are repeated elsewhere in this report in connection with discussions of R\&D needs for specific purposes.

1.5 Selected Examples of Current Studies Relating to Oil Recovery from Heavy-Oil Sources and Tar Sands

There is an extensive literature on many aspects of oil recovery from tar sands and heavy-oil sources. A useful sample of current research may be found in a monograph published in 1977.13 Topics include an overview of Alberta oil sands as a potential oil source and its geochemical history; included are the regional and cross-sectional maps reproduced in Figs. 1.5-1 and 1.5-2, respectively. K. N. Jha, D. S. Montgomery and O. P. Strausz (Ref. 13, pp. 33-54) discuss the composition of gases in Alberta bitumens and derived from low-temperature thermolysis of asphaltenes and maltenes; A. E. George, G. T. Smiley and H. Sawatzky (Ref.13, pp. 55-77) discuss changes in chemical composition during thermal hydrocracking of Athabasca bitumen; hydrocracking and separation are shown schmatically in Fig. 1.5-3. Laboratory studies

13 Oil Sand \& Oil Shale Chemistry, edited by O. P. Strausz and E. M. Lown, Verlag Chemie, New York and Weinheim 1978, Symposium on "Oil Sand and Oil Shale Chemistry, Montréal Québec, 1977. 
Table 1.4-1 Summary of research recommendations derived irom site visits and discussions (compiled from data in Appendix B).

\begin{tabular}{|c|c|}
\hline Applications & R\&D Requirements \\
\hline $\begin{array}{l}\text { Bitumen recovery from } \\
\text { mined Utah tar sands. }\end{array}$ & $\begin{array}{l}\text { Development of improved ambient and hot-water digestion- } \\
\text { floatation techniques; improved thermal recovery techni- } \\
\text { ques; shear stresses required to separate bitumens from } \\
\text { sands; separation of bitumens by air floatation; solvent } \\
\text { extraction of bitumens. }\end{array}$ \\
\hline $\begin{array}{l}\text { In situ recovery of } \\
\text { bitumen from tar sands. }\end{array}$ & $\begin{array}{l}\text { Evaluation of the relative merits of forward and of re- } \\
\text { verse combustion processes; comparisons of steam drive } \\
\text { and combustion techniques; identification of factors de- } \\
\text { termining recovery efficiencies; development of quantita- } \\
\text { tive models to define recovery efficiencies for well char- } \\
\text { acterized resources; recovery and cleaning of product } \\
\text { waters; development of down-hole steam generators. }\end{array}$ \\
\hline $\begin{array}{l}\text { Generic problems common } \\
\text { to many recovery pro- } \\
\text { cesses of oil from tar } \\
\text { sands. }\end{array}$ & $\begin{array}{l}\text { Use of coal in fluidized-bed combustors as fuel for steam } \\
\text { generation. Process-water purficiation; verification of } \\
\text { recovery performance; scale-up to commerical sizes; up- } \\
\text { grading and refining; minimization of steam-to-sand ra- } \\
\text { tios and of associated energy costs; downhole steam gen- } \\
\text { eration; control of heterogeneity effects. }\end{array}$ \\
\hline $\begin{array}{l}\text { Long-term research and } \\
\text { novel techniques rela- } \\
\text { ting to oil recovery } \\
\text { from tar sands. }\end{array}$ & $\begin{array}{l}\text { Resource assessments; use of RF heating; numerical model- } \\
\text { ing of resource beds during recovery; scale-up of opera- } \\
\text { tions; coke desulfurization and processing for feedstock; } \\
\text { upgrading and refining. }\end{array}$ \\
\hline $\begin{array}{l}\text { Oil recovery from heavy- } \\
\text { oil sources. }\end{array}$ & $\begin{array}{l}\text { Assessments of long-term toxicity of chemical compounds } \\
\text { used in heavy-oil recovery; production of stable foams (for } \\
\text { use in permeability control) at elevated temperatures; up- } \\
\text { srading and refining of recovered oils; mobility matching } \\
\text { to improve reservoir performance; reservoir flooding with } \\
\text { CO2, surfactants, polymers, or caustic compounds; utiliza- } \\
\text { tion of thermal recovery methods, fireflooding; analytical } \\
\text { procedures and distillate characterization; down-hole } \\
\text { steam generation; water availability and purity; migration } \\
\text { of added chemicals through the oil reservoir; degradative } \\
\text { pathways for chemicals introduced in EOR; adsorption and } \\
\text { mobility of chemicals used in EOR. }\end{array}$ \\
\hline
\end{tabular}




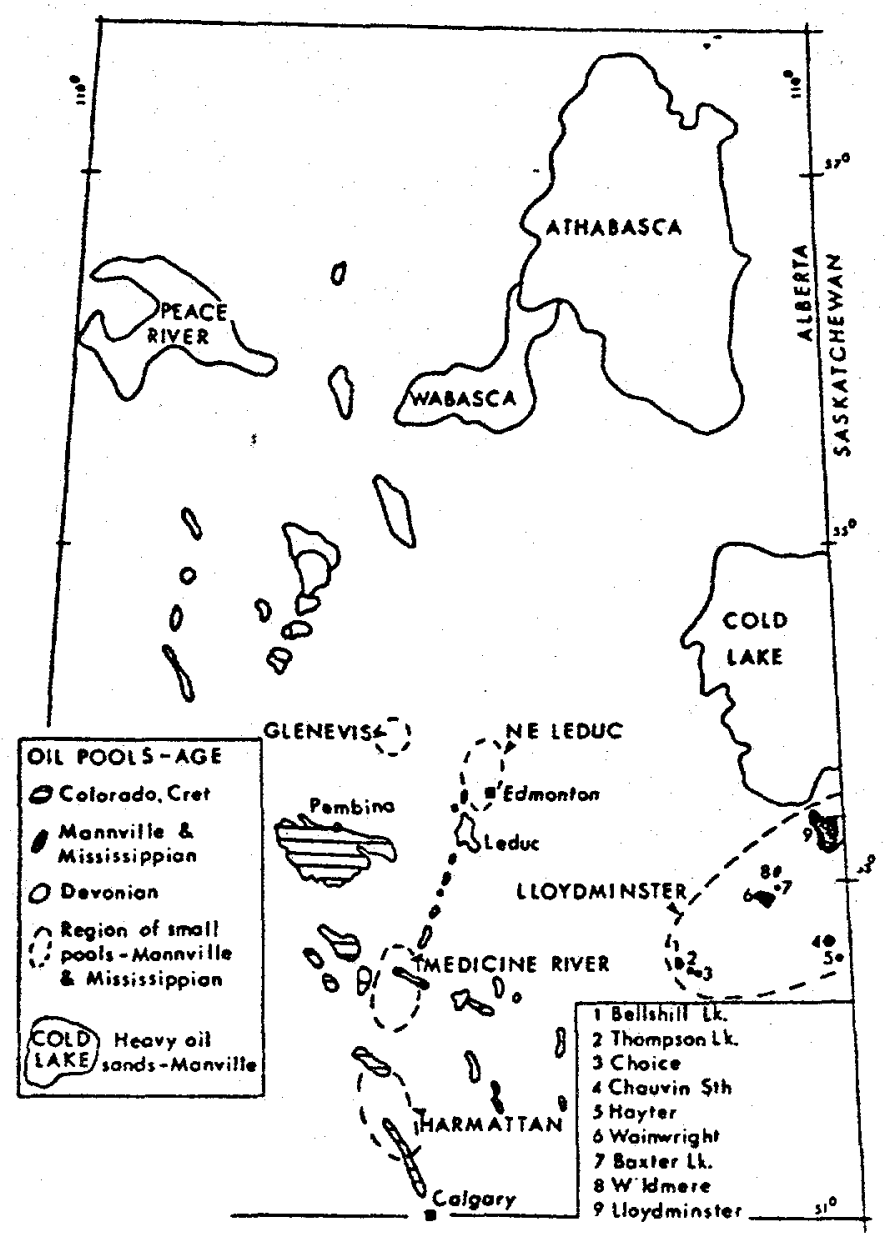

Fig. 1.5-1 Oil pools and oil sands deposits of Alberta; shown on page 12 of Ref. 13 in a paper by G. Deroo and T. G. Powell and reproduced from maps prepared by the Alberta Oil \& Conservation Board, 1963. 


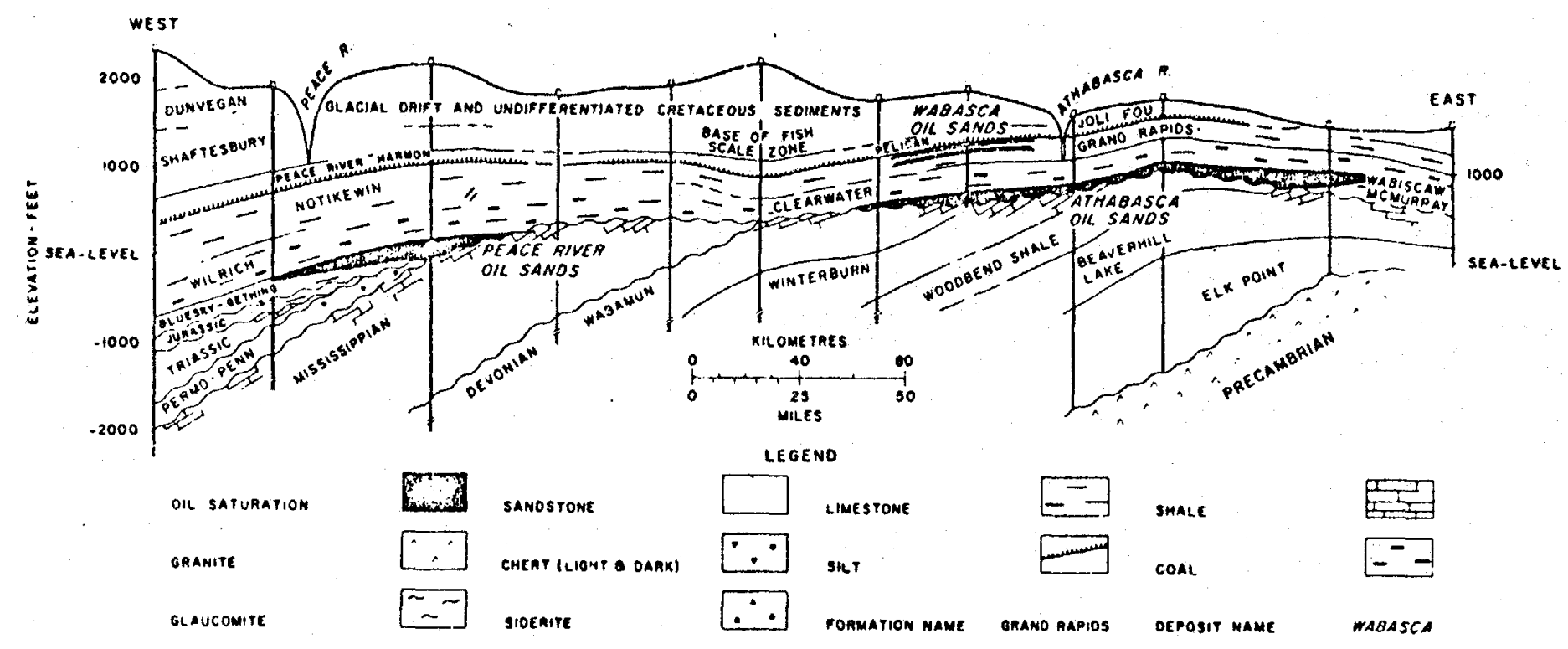

Fig. 1.5-2 Schematic cross-section (compare Fig. 1.5-1) between the western boundary of the Peace River deposit and the eastern boundary of the Athabasca deposit south of Fort McMurray (reproduced by $R$. D. Humphreys and $R$. Schutte on p. 3 of Ref. 13 and prepared by the Alberta Oil \& Gas Conm servation Board, 1963). 


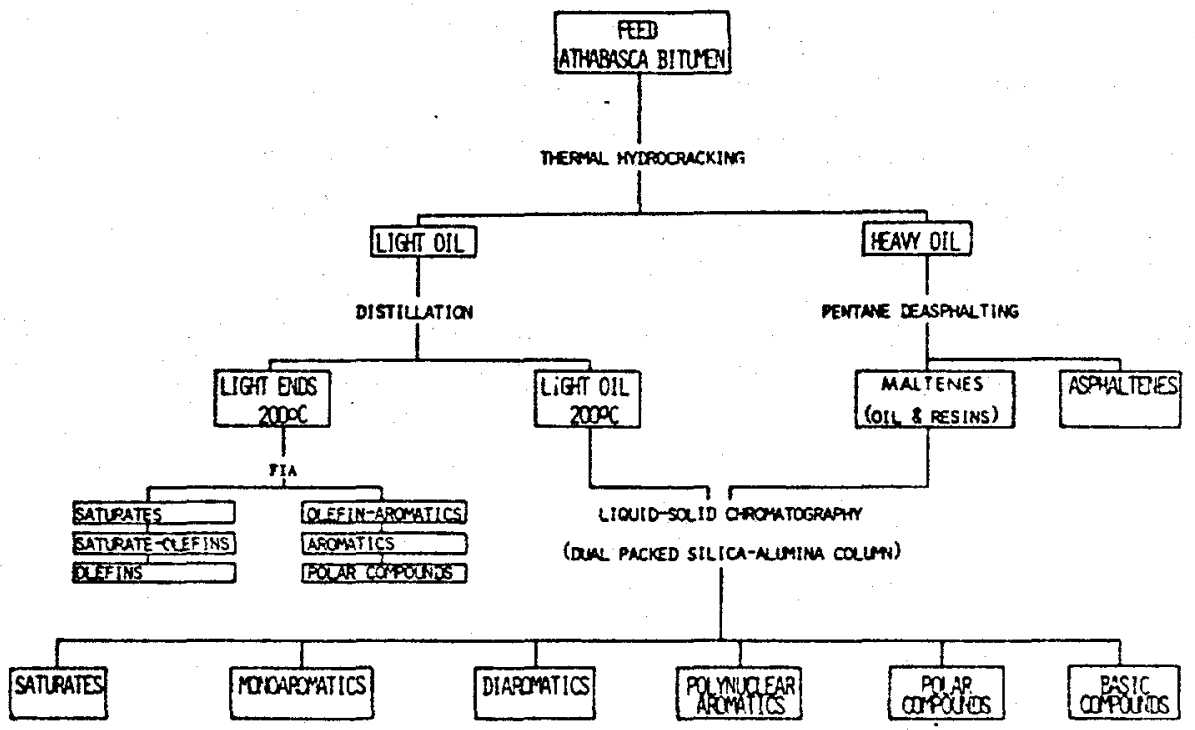

Fig. 1.5-3 Hydrocracking and separation scheme; reproduced from A. E. George, G. T. Smiley, and H. Sawatzky (p. 56 of Ref. 13). 
of fireflooding are described by D. W. Bennion et al (Ref. 13, pp. 79-100); weight loss of heated oil sands was studied as a function of time by P. C. Stangeby and P. L. Sears (Ref. 13, pp. 101-118), while separation of oil sand bitumens into geochemical constituents forms the subject of a study by M. L. Selucky, T. C. S. Ruo, and O. P. Strausz (Ref. 13, pp. 119-144). Microbial extraction of bitumen from oil sands was examined by $J$. E. Zajic and D. F. Gerson (Ref. 13, pp. 145-161), whereas R. J. Crawford, C. Spyckerelle, and D. W. S. Westlake (Ref. 13, pp. 163-176) and I. Rubinstein and O. P. Strausz (Ref. 13, p p. 177189) studied biodegradation of oil reservoirs and its relation to the origin of the Alberta oil sands; the degradation of aromatic hydrocarbons by bacteria and fungi is further discussed by $C$. $E$. Cerniglia and D. T. Gibson (Ref. 13, pp. 191-210). Other topics considered in Ref. 13 include comparisons between natural and synthetic asphaltenes (pp.211-222) and the nature of sulfur compounds found in heavy oils, oil sands, and oil shales (pp. 223-243).

A major additional publication dealing with oil recovery from heavy oils and tar sands has been published recently. ${ }^{14}$ The following representative publications dealing with R\&D are included: numerical simulation of a steam drive; identification of critical problem areas in oil recovery from Alberta tar sands, including cost reductions in overburden removal and handling, Clark-process modifications to allow shortened water-recycle times in tailing ponds, recovery from "oil-wet" sands, economical recovery from deeply buried sands and thin zones, bitumen recovery from carbonates, clean-up and reuse of product water (C. W. Bowman and M. A. Carrigy); innovative approaches for heavy $\left(10-22^{\circ}\right.$ API ) crude processing, including the use of solvents (e.g., pentanes-plus) to effect $35-55 \%$ recovery with low

${ }^{14}$ UNITAR, First International Conference on the Future of Heavy Crude and Tar Sands, Alberta, Canada, 1981. 
solvent losses, use of agents to prevent viscosity increases in the well and production string, use of such compounds as polyisobutylines to serve as "slickers" in pipelining, fireflooding with $\mathrm{O}_{2}$ or oxygen-rich air to reduce air-compression costs, metabolic processes involving applications of bacteria or enzymes, generation of open-cycle steam in a wet combustion process to increase the ratio (product oil value/steam cost)( $\mathrm{Z}$. G. Havlena); new ways for upgrading of tars and heavy crude ( $F$. $H$. Adams et al); recovery of residual bitumen from aqueous tailings by sparging (E. S. Hall and E. L. Tollefson); role of asphaltenes in heavy crudes and tar sands ( $T$. F. Yen); heavy crude oil and tar sand resources in the U.S. (R. L. Whiting); pipeline transportation of heavy oils (A. Sloan et al); fuels and chemicals from heavy crude and tar sands ( $J$. W. Mohlman); experimental and mathematical modelling of in situ combustion in oil recovery ( $A$. Satman et al); radiofrequency heating to recover oil from Utah tar sands. ( $J$. Bridges et al); water conservation in a steam stimulation project (M. J. Whalley and T. M. Wilson); stress and volume changes in gas-saturated, very dense sands ( $M$. B. Dusseault); the chemistry of oil sand bitumen (D. P. Strausz); introduction to heavy oil upgrading ( $J$. M. Wilkinson). 
CHAPTER 2

RESOURCE ASSESSMENTS

\subsection{Introduction and Definitions}

\section{1 .1 Introduction}

The definition of tar sand is presently being considered by DOE as a hydrocarbon resource having a viscosity at reservoir temperatures of $>10,000 \mathrm{cp}$ and the deposit must be produced through mining. Heavy oil, on the other hand, has no such clear definition. Many surveys do not include viscosity with resource descriptions. For the purpose of this chapter, we shall consider oils on a specific gravity basis rather than a viscosity basis as this property is more closely related to crude chemical properties and significance to upgrading. Viscosity relates crudely to specific gravity though correlations are highly scattered. Examples are provided in Table 2.1.1-1, where we show specific gravities and viscosities of various crudes.

The significance of these data to production can be realized by considering that at $60^{\circ} \mathrm{F}$ conventional crudes of 30-45 API have viscosities of only 3.5-48 centipoise and thus require several orders of magnitude less force to move through the ground than would be needed for heavy crudes.

The gravities of the heavy oil or bitumen deposits appear to center around $8-12^{\circ} \mathrm{API}$, but the observed range in some reservoirs is greater or may be shifted by several degrees toward lower or higher gravities. There is no generally accepted gravity definition for heavy oil. 
Table 2.1.1-1. Variations in viscosity with API ${ }^{a}$ gravities (see Refs. 1 and 2). Modified from data in Leverson (1956),$^{1}$ Carrigy \& Kramers $(1973)^{2}$ and selected journals.

\begin{tabular}{|l|c|c|c|}
\hline Bitumen from & $\begin{array}{c}\text { Specific } \\
\text { gravity }\end{array}$ & $\begin{array}{c}\text { OAPI } \\
\left(60^{\circ} \mathrm{F}\right)\end{array}$ & $\begin{array}{c}\text { Viscosity } \\
\text { (centipoise) } \\
\left(100^{\circ} \mathrm{F}\right)\end{array}$ \\
\hline Bradford, Pennsylvania & 0.801 & 45.2 & 2.81 \\
Rodessa, Texas & 0.812 & 42.8 & 3.14 \\
Abqaig, Saudi Arabia & 0.840 & 37.0 & 3.55 \\
Rangely, Colorado & 0.850 & 35.2 & 4.88 \\
Walters, Kansas & 0.879 & 29.3 & 17.47 \\
Lagunillas, Venezuela & 0.948 & 17.8 & 203.50 \\
Spring Creek, Wyoming & 0.980 & 12.6 & $1,276.20+$ \\
Cold Lake, Alberta & 1.003 & 9.5 & $200,000 \mathrm{C}$ \\
Athabasca, Alberta & $1.0-1.02$ & $10.0-6.0$ & 300,000 \\
& & & $30,000,000 \mathrm{C}$ \\
\hline
\end{tabular}

a. In this chapter, API gravity is used as the measure of specific gravity. High API gravity is an indication of good quality to a refiner. Specific gravity and API gravity are related as follows:

$$
{ }^{\circ} \mathrm{API}=\frac{141.5}{\mathrm{sp} \cdot \mathrm{gr} \cdot \mathrm{at} 60 / 60^{\circ} \mathrm{F}}-131.5 .
$$

Thus, a crude with API = 10 has the specific gravity of water and crude with API gravity higher than 10 will float while that with less than 10 will sink in water.

b. One centipoise equals $1 / 100$ of a poise. A fluid has a viscosity of 1 poise when a tangential force of 1 dyne causes a plane surface of $1 \mathrm{~cm}^{2}$ area, spaced $1 \mathrm{~cm}$ from a stationary plane surface, to move with a constant velocity of $1 \mathrm{~cm} / \mathrm{sec}$, the space between the planes being filled with the viscous fluid (API Bul. 228, 1941 ).

c. Viscosities measured at $60^{\circ} \mathrm{F}$.

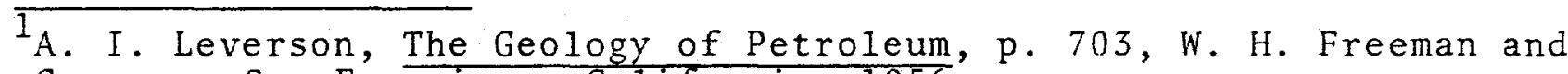
Company, San Francisco, California, 1956.

${ }^{2}$ M. A. Carrigy and J. W. Kramers, editors, "Guide to the Athabasca Oil Sands Area," p. 213. Contribution No. 628, Information Series 65, Alberta Research Council, Edmonton, Alberta, Canada, 1973. 
Dietzman ${ }^{3}$ defined heavy oil as having a gravity of $25^{\circ}$ API or less. However, much oil in the range $12-25^{\circ}$ API is producible "in its natural state through a well by ordinary production methods." In fact, still flowing giant fielas have oil with gravities of $12-20^{\circ}$ API (e.g., in Mexico: Ebano-Panuco, $12.5^{\circ} \mathrm{API}$ and exceptionally high viscosity of about 1,500 centipoise at $122^{\circ} \mathrm{F}$; Golden Lane, average $20^{\circ} \mathrm{API} ;$ in Venezuela: Tia Juana/Maracaibo, average $\left.18.8^{\circ} \mathrm{API}\right)$. In eastern Venezuela, the giant Quiriquire field, with $16.3^{\circ}$ API oil, was initially flowing. An earlier survey by the Bureau of Mines assessing the resource, reserve and potential for production of heavy oils in the united states also defined heavy oils as $<25^{\circ}$ API. ${ }^{4}$

Heavy oils as defined in this chapter include all naturally-occurring petroleum resources having API gravities of less than 20. Crudes of this nature generally are highly viscous and flow only slowly unless heated. This makes them difficult to produce and transport. Even with the least viscous heavy oils, less than $10 \%$ of the oil in place can be produced by primary means (natural pressure or pumping). Heavy oils contain high concentrations of asphaltic components and normally less than $50 \%$ can be distilled. These features make them unacceptable as major feedstocks to present-day refineries.

Waxy crudes, which are not discussed in this chapter, have higher API gravities (generally $>20$ ). Although they are also difficult to produce and transport, they may be upgraded with existing technology and are acceptable major feedstocks to present-day refineries.

\footnotetext{
3.D. Dietzman, M. Carrales, Jr., and C.J. Jirik,

"Heavy Crude Oil Reservoirs in the U.S., a Survey." U.S. Dept. Int., Bur. Mines, Inf. Circ. 8263, Washington, D.C., 1965.

${ }^{4}$ Bureau of Mines Circular 8352 "Heavy Crude Cil - Resource, Reserve and Potential Production in the U.S." U.S. Dept. of Interior, Washington, D.C., 1967.
} 
The above definition for heavy oils encompasses a wide variety of petroleum resources, which have been referred to by a number of different subclassifications.

\subsubsection{Definitions of Heavy Oil Classifications}

All heavy oils fall within the broad classification of bitumen. A bitumen is defined as any petroliferous, naturally-occurring material which is extractable by common organic solvents (usually $\mathrm{Cs}_{2}$ ) from the rock in which it is found or, when not associated with rock, it can be dissolved. These bitumens are all dark in color (black or deep brown) and exist as solids or highly viscous liquids at room temperature.

Within the classification of bitumen, there are a number of subclassifications which overlap; distinctions between these have often been arbitrary. These subclassifications are summarized in Table 2.1.2-1 and are defined below. They are listed in increasing order of desirability as feedstocks to present-day refineries.

Table 2.1.2-1 Classification of heavy oils.

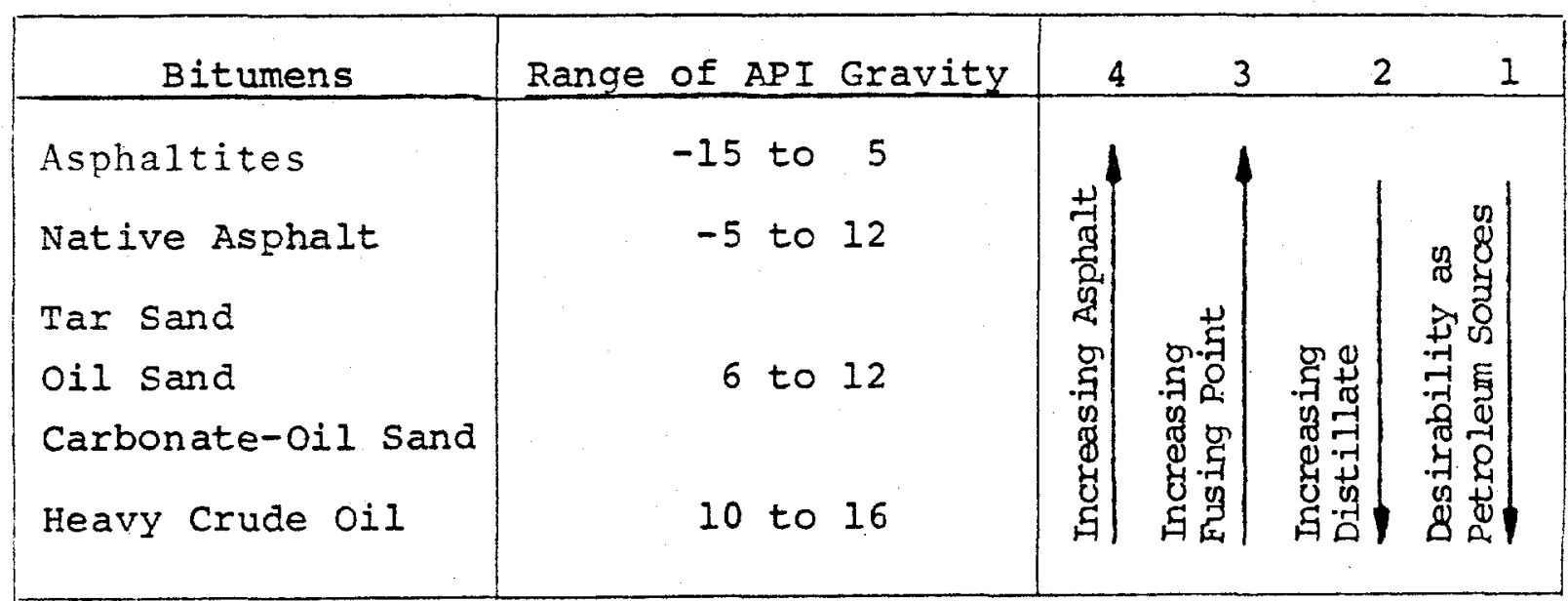


Asphaltites ${ }^{5}$ These are natural solid bitumens which generally are not associated with rock. They have API gravities in the range of $-15^{\circ}$ to $5^{\circ}$, exhibit high fusing points $\left(>230^{\circ} \mathrm{F}\right)$, and contain little or no distillable components. On pyrolysis $\left(800^{\circ} \mathrm{C}\right.$ ), they leave $>20^{\circ}$ carbonaceous residue (fixed carbon). Most materials of this type are considered to be organic minerals and have been so named. Representative examples are gilsonite and uintaite which are prevalent in Utah, glance pitch (or Manjak) found in Mexico, South America and the Mid West, and grahamite which is found in North and South America.

Native Asphalt ${ }^{5}$ Bitumens of this type have API gravities in the range of $-5^{\circ}$ to $12^{\circ}$, are generally fusible at $<200^{\circ} \mathrm{F}$, and contain small amounts of distillate. They may or may not be found in association with porous rock. Traditionally, these materials have been used as caulking materials for boats or for road paving. Representative examples are found in Asphalt Ridge (Utah), Santa Cruz (California), Asphalt Lake (Trinidad), and Guanoco Asphalt Lake (Venezuela).

Tar sand, oil sand, Carbonate-oil sand The majority of the heavy oils fall within this category. API gravities range from $6^{\circ}$ to $12^{\circ}$, bitumens are semi-solids or viscous liquids at room temperature, and they contain significant amounts of distillates. The majority of these resouces are found in single,massive deposits. Representative examples are the Athabasca oil sands of Alberta, the orinoco Tar Belt of Venezuela, the Melekess Oil Sands of Russia.

${ }^{5}$ H. Abraham, Asphalts and Allied Substances, Vol. 2, D. Van Nostrand Company, Inc., Princeton, New Jersey, 1960. 
Heavy Crude Oils These bitumens are all viscous liquids having API gravities in the range of 10 to 20 and generally contain $>30 \%$ of distillable materials. They represent the only subclass of heavy oils which can be produced by primary methods (natural pressure or pumping). Generally, primary production yields $<10 \%$ of the oil in place.

Representative examples include the following oil fields: San Ardo (California), Lloydminster (Alberta), Gela (Italy), Ebano Pancuo (Mexico), and Boscan (Venezuela).

The significance of tar sands and heavy oils is that they are potentially the third most abundant energy source in the world and the largest source of naturally-occurring petroleum. Several single deposits of heavy oils individually contain more petroleum than the total known world reserves of conventional light oil. 6 However, they have not been exploited.

Heavy oils were historically the first petroleum resources to be utilized by man. Several references to the use of heavy oil for caulking boats occur in the Book of Genesis, and the first directly recorded uses were in 38002500 B.C. by the sumerians. 5 The reason for their early exploitation is the fact that heavy oils often occur as natural seepages or at shallow depths.

Generally, in a given location, heavy oils follow a rule-of-thumb that the API gravity increases with depth. Thus, the most accessible oils have the lowest value as sources of the petroleum hydrocarbons that are presently

${ }^{6}$ G.J. Demaison, "Tar Sands and super Giant Oil Fields," presented at the $157 \mathrm{th}$ Meeting of CIM, Canada-Venezuela Oil Sands Symposium, Edmonton, Alberta, May 1977. 
needed. An unfortunate aspect of compositional difference with depth is that the credibility of reserve statistics also decreases with depth. Heavy crudes of low API gravity (1020 API) are often disregarded in present statistical surveys as they are often classified as unproducible by conventional techniques. Although many heavy oils occur as massive single deposits, within most deposits there are multiple seams or producible zones. The oil in these zones may be from the same or a different source and can therefore have different physical and chemical properties. Generally, lower zones have higher API gravities and lower viscosities and are therefore easier to produce. 7 Within a single deposit, if one portion of the field is near the surface and another portion is deep, the quality of the crude may vary with increasing depth. 8 API gravity is highest in lower levels, and commonly the paraffin content increases with depth. Examples of the various types of deposits and production zones in which heavy oils are found are illustrated in Figs. 2.1.2-1 through $2 \cdot 1 \cdot 2-4$.

Because of the complexity of multiple seams and varying quality with depth, no distinction will be made as to the quantity of the individual subclasses or different quality crudes found within a given geographical location. Accordingly, the quantity of bitumen which is found in different locations will be referred to as the amount of oil in place and will be defined as the resource for that location.

7F.J. Gutierex, "The orinoco Tar Belt of Venezuela," in Ref. 6.

${ }^{8}$ C.W.D. Milner, M.A. Rogers and C.R. Evans, J. Geochem. $\operatorname{Exp} 1$. I, 101 (1977). 


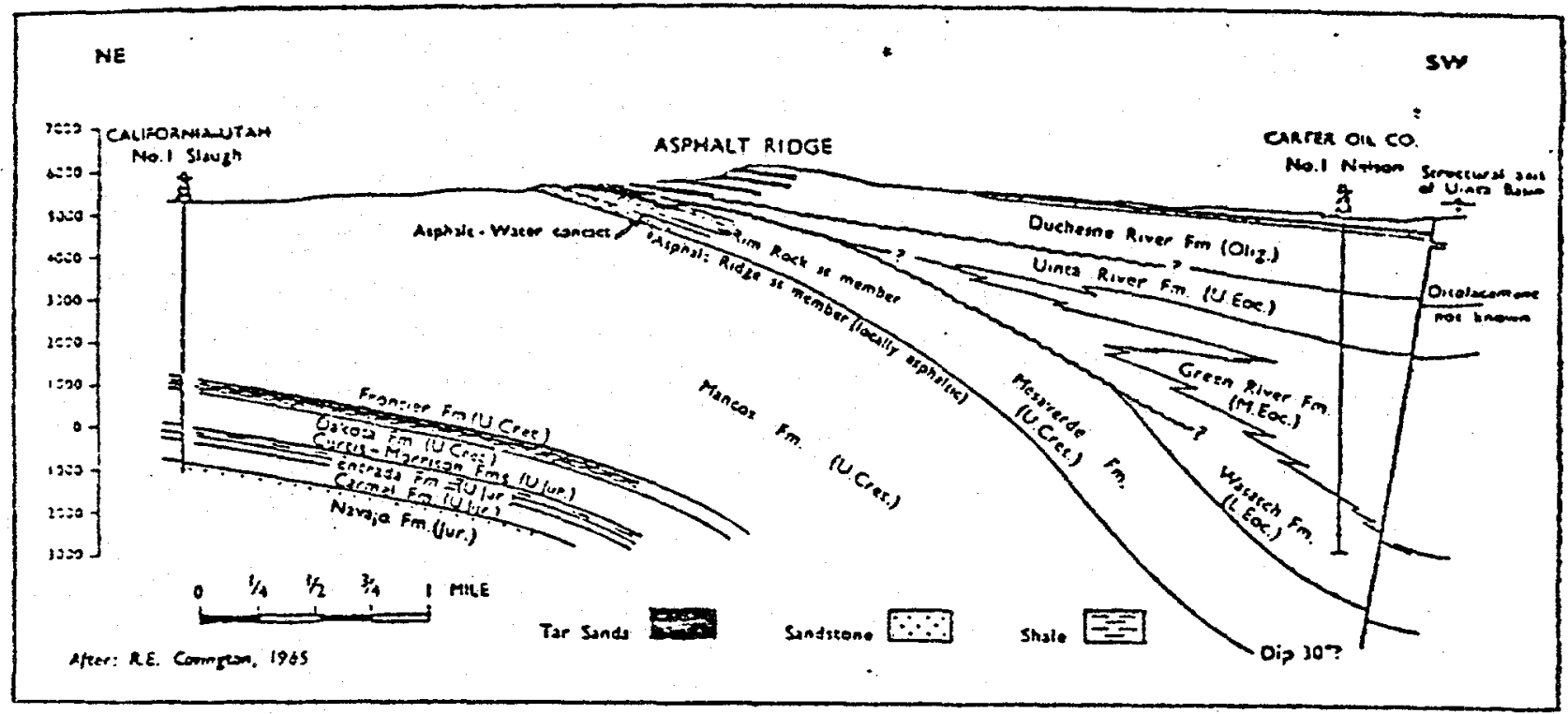

Fig. 2.1.2-1 Geologic cross profile, Asphalt Ridge Area, Utah.9

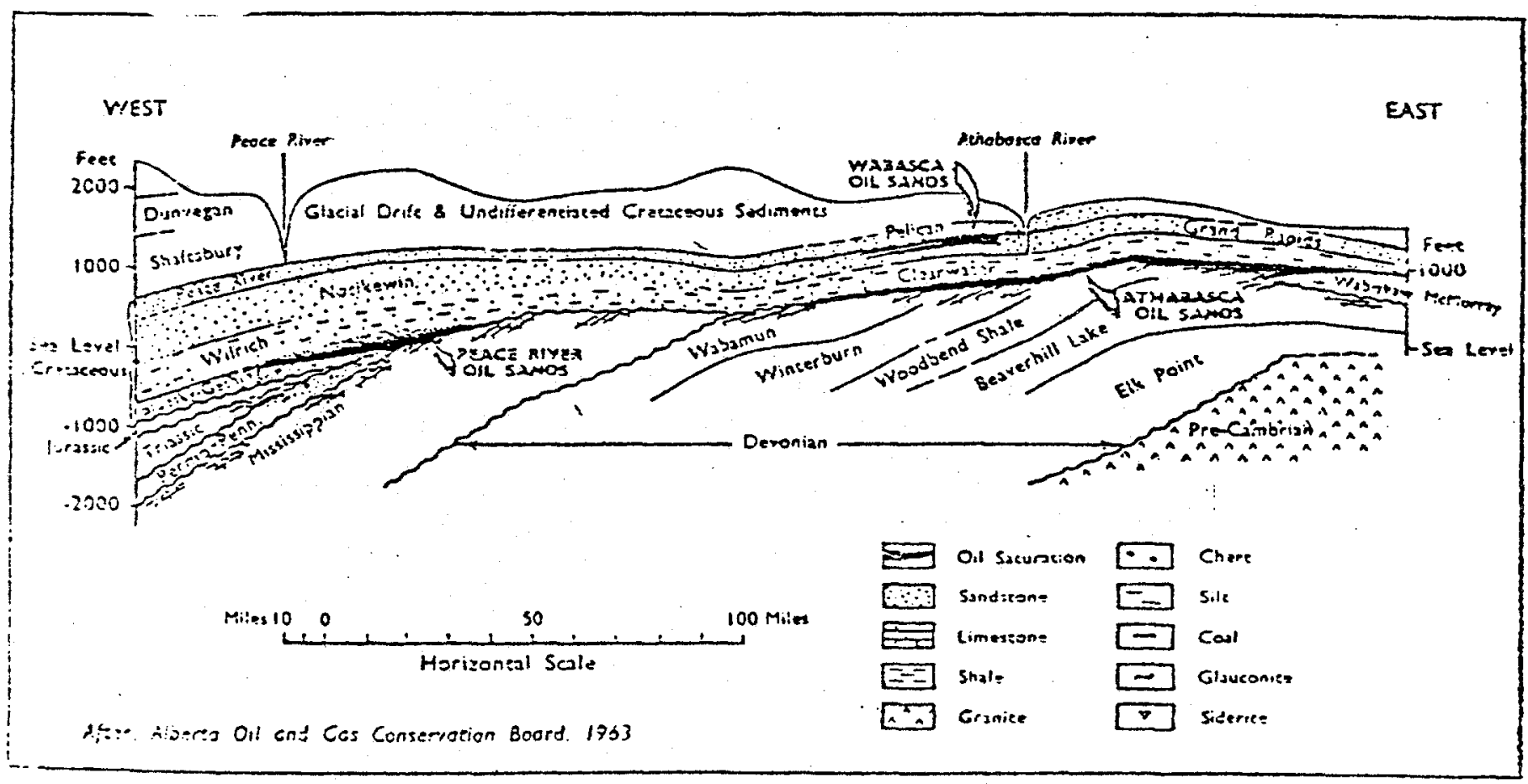

Fig. 2.1.2-2 Schematic geological E-W cross section showing the geglogical setting of the Athabasca Tar
Sands. 9

Many heavy oil deposits occur in multiple zones and often in different formations. As shown above, Wabasca consists of two formations. San Ardo, California (not shown in this figure) similarly has two production zones. Lower lying formations generally have higher API gravities.

${ }^{9}$ P.H. Phizackerley and I.O. Scott, "Major Tar Sand Deposits of the World," presented at the 7th World Petroleum

Congress $\underline{3}, 551$ (1967). 


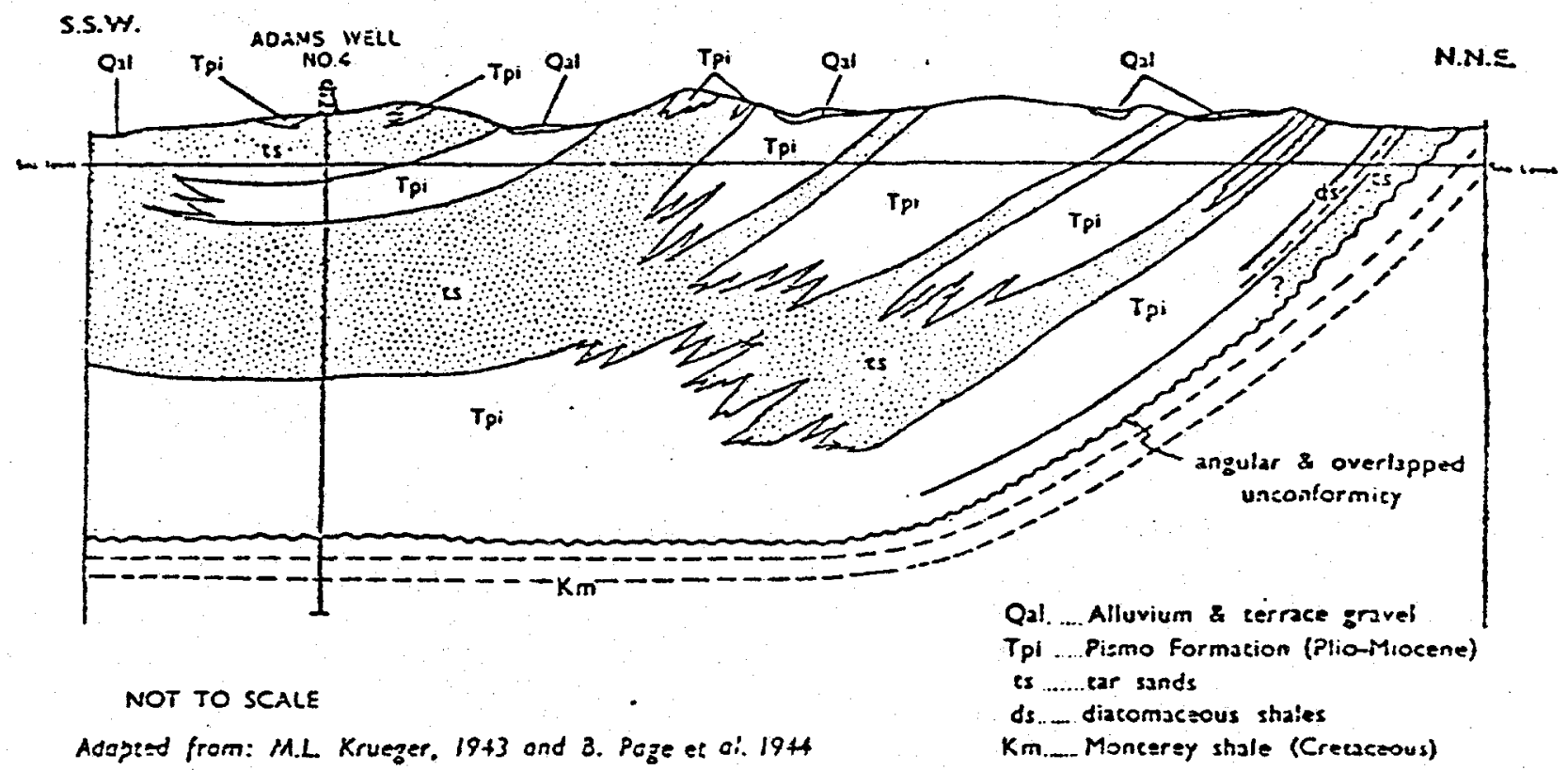

Fig. 2.1.2-3 $\begin{aligned} & \text { Diagrammatic section through Edna Tar Sands, } \\ & \text { California.9 }\end{aligned}$ Some heavy oil deposits are composed of formations which extend from reasonable depths to the surface. In these instances, the quality of the crude can vary considerably with depth as biological degradation of the crude near the surface can cause major compositional changes.

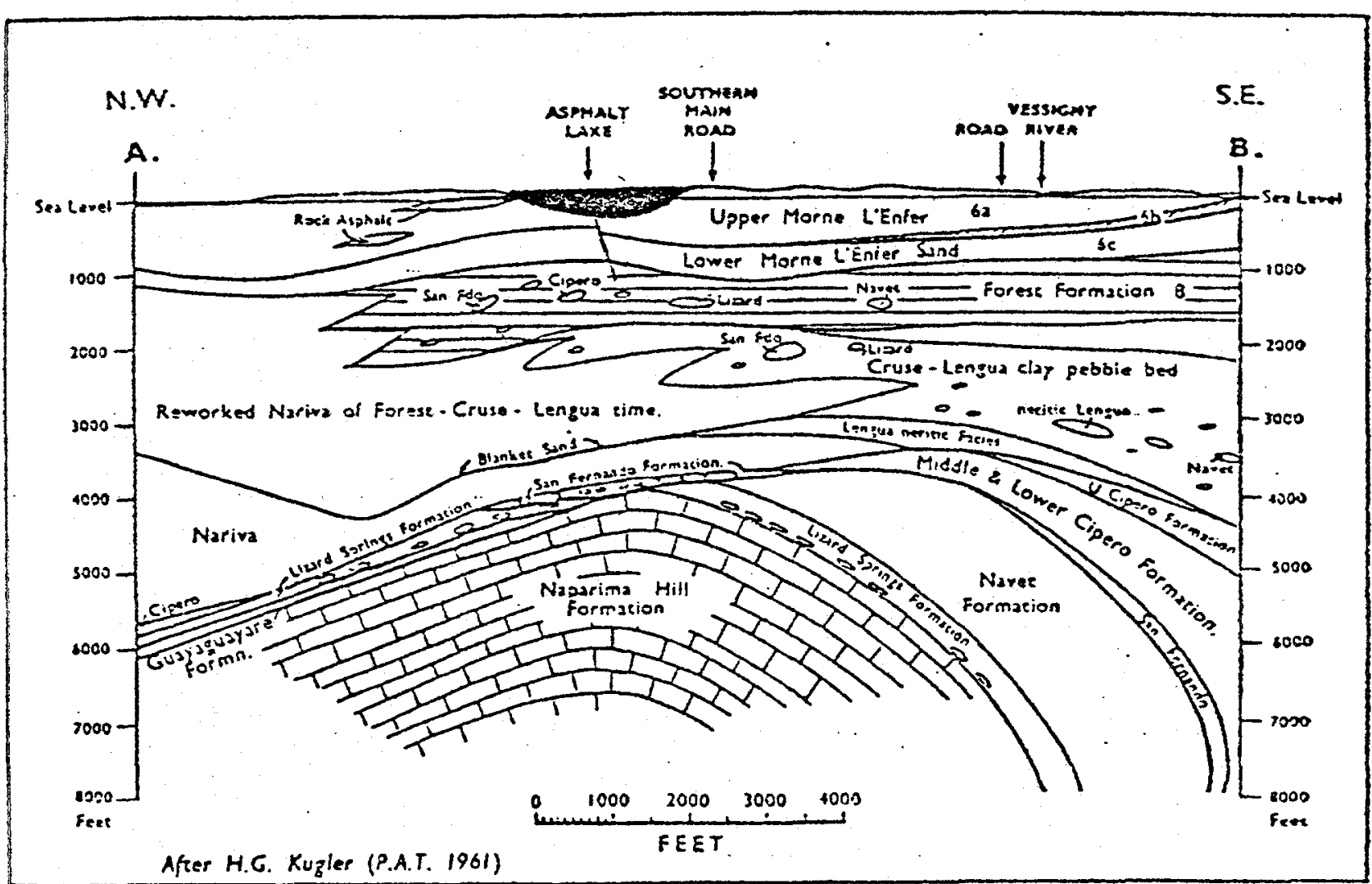

Fig. 2.1.2-4 NW-SE geological section through Trinidad Asphalt Lake Area. 9

In a few instances, heavy oils occur in massive deposits of almost pure bitumen,as in the case of asphalt lakes. 
2.2 Available Physical Property Data

on Tar Sands and Heavy Oils

To assess the value of a given crude, physical property data are very important. Crude oil physical property data are scattered in a multitude of reports that vary from detailed analytical and processing studies 10 to a mere listing of API gravity and sulfur. Viscosity data are very often omitted in present surveys.

(1) A systematic accumulation of data is, however, furnished by the Bureau of Mines as assays in the form of a multitude of Research Investigations (RI) of various crudes. Data reported by the Bureau of Mines are exemplified by Table 2.2-1 for 11.1 'API San Ardo, California, crude. In addition to these printed RI, data for 9,000 Bureau of Mines assays are available in the form of punched cards in Fortran language for computer-manipulated searches.

(2) Another source of information is API search tapes, including Petroleum Abstracts. References retrieved by these searches refer only to information published in the standard literature and do not include proprietary assay data published by oil companies or the Bureau of Mines. Typical printouts are shown in Table 2.2-2.

Viscosity data, which are critical to production assessment for heavy crudes at different temperatures, are poorly documented. However, from available data it may be concluded that the viscosity change with temperature is fairly uniform for crudes with the same viscosity. Furthermore, the viscosities of the majority of heavy crudes appear to respond to

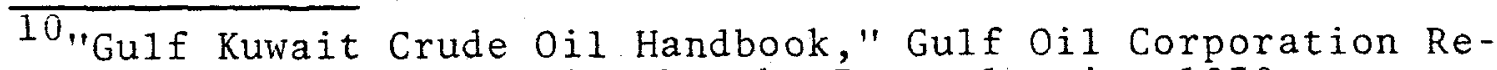
port No. 753RA006, Pittsburgh, Pennsylvania, 1970. 
Table 2.2-1 A representative Bureau of Mines data report.

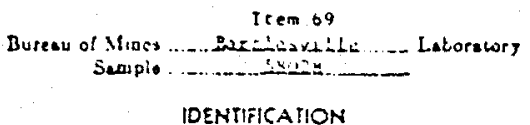

San Ardo tield Lombazi, Muviene $2,100-2,250$ tees

Casterasas Monkesey Councy

GENEPAL GHARAGERISTOS

Geritg, ipeci6e. ....-0.99?. Sultur, percent, ......2.25

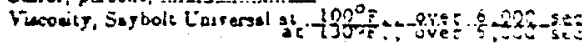

Pois poiat, F., $-90 \ldots . . . . . . . . . . .$.

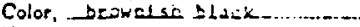
Gravity. $1 \mathrm{Pi}, \ldots$...

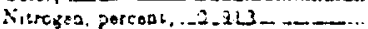
DISTLLATION SUREAU OF MINES ROUTHNE METHOD

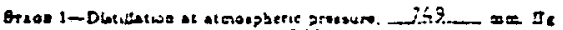

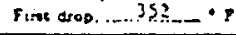

\begin{tabular}{|c|c|c|c|c|c|c|c|c|c|c|}
\hline $\begin{array}{l}\text { Treives } \\
\text { No. }\end{array}$ & 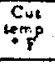 & Perreos & Sum.: & 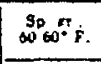 & 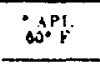 & c. 1 . & 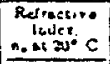 & $\begin{array}{l}\text { Zuestic } \\
\text { dispefutuo }\end{array}$ & $\begin{array}{c}80 \\
50 \\
100^{\circ} 8 .\end{array}$ & 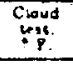 \\
\hline & 122 & 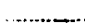 & $\ldots$ & & . & & $\ldots$ & .......... & & \\
\hline & 188 & & .......... & 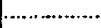 & 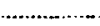 & & ................... & . & & \\
\hline$\ldots \ldots$ & $2: 3$ & .............. & ........n.... & .................... & $\ldots \ldots$ & ,........ & . . . . . & 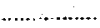 & & \\
\hline & 257 & ............ & 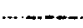 & $\ldots+\cdots+$ & ................... & .................... & ................... & $\ldots .$. & & \\
\hline & 302 & $-\ldots \ldots \ldots$ & ... & $1-\ldots$ & .................. & .................. & $\ldots \ldots \ldots$ & ............... & & \\
\hline & 347 & & & & & & & ................ & & \\
\hline 7 & 982 & $\ldots .0$ & . & $0,832 \ldots$ &. .38 .6 & ......... & .................... & 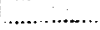 & & \\
\hline & NI & 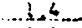 & $\ldots 2+4$ & .. .861. & $\ldots .32-3$. & ......... & $\ldots \ldots$ & $\ldots \ldots \ldots$ & & \\
\hline & 182 & 64 & $\ldots+5$ & 86 & 3 & 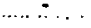 & {$[1-4547]$} & $\ldots 125.6$ & & \\
\hline
\end{tabular}

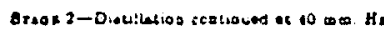

\begin{tabular}{|c|c|c|c|c|c|c|c|c|c|c|}
\hline & 393 & $\therefore=9$ & 11.4 & $0.89 ?$ & 37.1 & & 11.6 & LiLL. & .4] & S \\
\hline $12 .$. & WT & 5.3 & 16.9 & ... 909 & 2.7 & $.5 B$. & $1 L_{-} 49896$ & $.155 . .4$ & 52 & - \\
\hline 13 & 493 & 6.3 & 23.2. & .930 & 65 & ...65t. & $1.51200 \ldots$ & $\ldots 161.6$ & 93. & ـمثـ. \\
\hline 14 & 537 & $.3,2$ & 26. & $\ldots .246$ & & & 1.52365 & 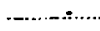 & 200 & Sen-n. \\
\hline $18 \ldots \ldots$ & ה & 72.0 & 98.4 & 1.225 & 6.6 & & & & & \\
\hline
\end{tabular}

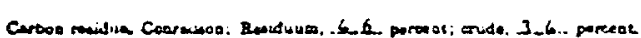

ARPROXIMATE SUMMARY

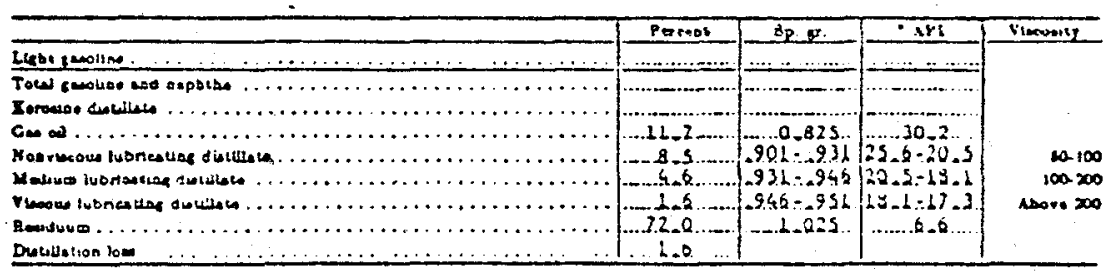

If Otaltistion discontinued at $482^{\circ} \mathrm{F}$.

$\underline{2}$ t Diselilacton discones nued of $309^{\circ} \mathrm{g}$. 
Table 2.2-2 Example of data retrievable from API tapes.

PHYSICAL PROPS OF HEAYY OILS \& BITUHENS - 76-218 (ENGLISH)

PAGE 1 PHYSICAL PROPS OF HEAVY OILS \& BITUNENS - 76.218 (ENGLISH)

$A N \cdot 225184$

TI - aVefage temperafure measurel:ient i" storage tanKS

AU - LEAVER R:H

SO - PETROL TINES V EC. NO 2031. PP 38.41.7/9/76

DE - $\angle$ BOVEGROLND STIIR FACILITY:- aVERAGING: calculatiNG: Change: CONIECTION: CONUERSION: CRUCE OLL. OENSITY: DETECTOR: -ELECTAICAL PRORERTY: EMPIRICAL ANALYSIS: ENGLISH: FLOW MEASURIHG: FLORMETER: FLUIO FLOH: GRADIENT: HEATING. HEATING EQUIPIAENT: -INSTRUIENT: MATHEMATICAL ANGLYSIS: MATHEMATICS: REASURING: OIL DENSITY: PETROLEUM: - PHYSICAL PROPERTY. POVIER: PRODUCT: -RESISTIVITY: SOLLR ENEGGY: -STORAGE FACILITY: TANK: TEMPERATURE MEASURING: TEST PROBE: TESIING: THERIMAL GRAOIEHT: THEFHAL PROPERTY:

- THERMOMETER: VISCOUS CRUDE OIL: VOLUME

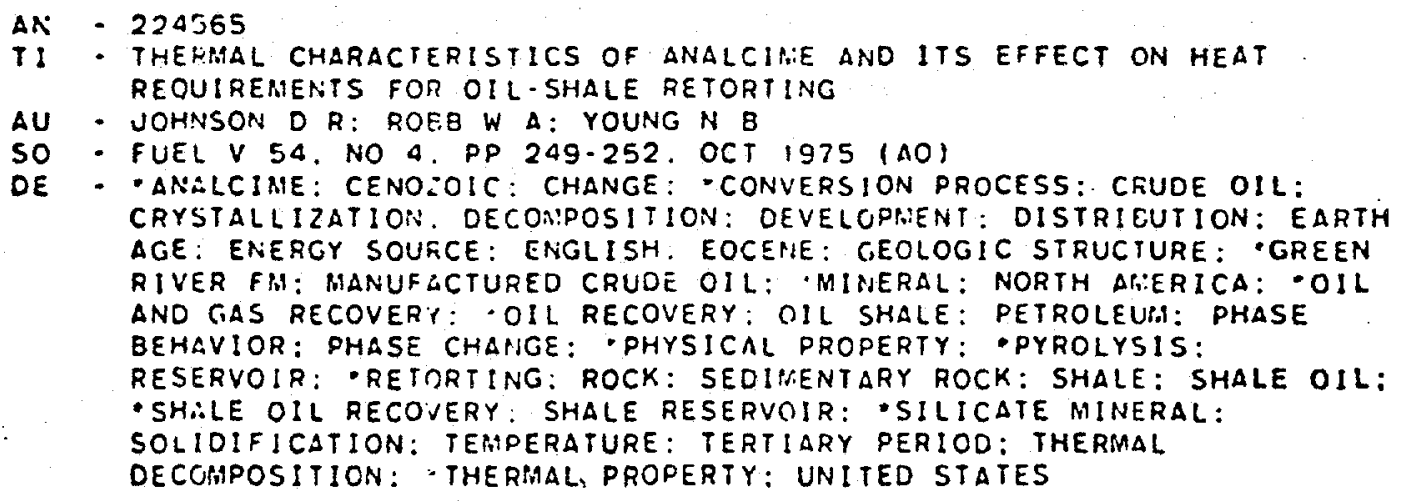

TI - PROTERTIES OF UTAH TAR SANDS: NORTH SEEP RIDGE AREA. P.R. SPRING DEPOSIT

AU - CUPFS C O: JOHNSON L A: MARCHANT L $C$

SO - LARLIMIE ENERGY FES CENTER REP NO LERCIRI--75/6. 19 PP. NOY 1975 (AO)

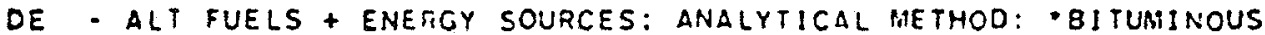
SANOSTONE: CHATACTERISTIC: COMPOSITION: CRUDE OIL: DENSITY: - ENERGY SOURCE: ENGLISH: FLUID PROFERTY: FORMATION THICKNESS: MANUFACTURED CRUDE OIL: NITROGEN CONTENT: NORTH ARIERICA: OIL AND GAS RECOVERY: OIL RECOVERY: OIL SATURATION: P R SPRING AREA: PERGEABILITY: PERMEABILITY (ROCK): PPETROLEUIA: PHYSICAL PROFERTY: PORE VOLURE: POROSITY: POROSITY (ROCK): -RESERVOIR CHAAACTERISTIC: RESULT: -ROCK. -SANDSTONE: SATURATION:

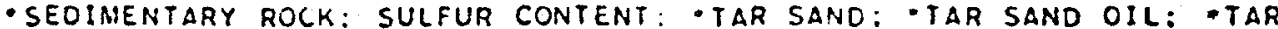
SANO OIL RECOVERY: TESTING: THICKNESS: UNITED STATES: UTAH: VISCOUS CRUDE OIL: VOLUME 
changes in temperature in a common manner. It is unlikely to cause unusual changes in viscosity by a simple change in the temperature of a heavy crude. However, it has been reported that some heavy crudes are non-Newtonian fluids and some shear stress has to be applied before movement begins. This has been found to be very important in pipelining venezuelan heavy oils.11 The yield point as a function of temperature for a variety of heavy crudes gave a fairly linear response for most crudes. However, in one case (PAO-IX, a Venezuelan crude), a very sharp change in yield point with a small change in temperature was observed. 11 This fact indicates the importance of considering other approaches to traditional observations, e.g., ASTM viscosity, obtained for normal crudes. It has been recommendedll that all viscosity measurements for heavy oils should be made under at least one standard shear rate. The viscosity is dramatically reduced with an increase of shear rate up to $401 \mathrm{bs} / 100 \mathrm{ft}^{2}$; beyond that point, little effect is noted.11 Reduction of viscosity by blending with cutter stocks is an extensively used and well-defined procedure in the manufacture of heavy fuel oils from residues. However, the use of such a procedure for viscosity reduction of heavy crudes is not well defined or documented. Information of this nature should be obtained and included in reports of crude oil physical properties to aid in assessment potential.

Lack of critical physical data often limits the credibility of resource assessment. A recommended list of physical properties to be determined on U.S. heavy crudes is provided in Table 2.2-3.

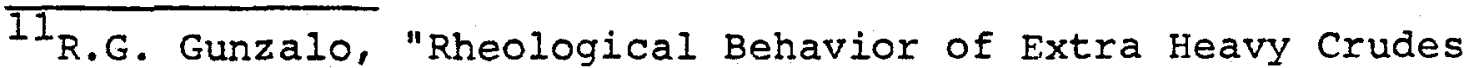
from the orinoco Petroleum Belt," presented at CanadianVenezuela Oil Sanas Symposium 77; Edmonton, Alberta, May 31, 1977. 
Table 2.2-3 Desirable compositonal and production data for heavy oils for inclusion in heavy crude assay databanks.

\section{Geographical, Geological and Production Summary}

\author{
Crude Name \\ Sample Identification \\ Name of Field \\ Field Location \\ state Name \\ County Name \\ Geological source \\ Name of Formation \\ Age of Formation \\ Depth of Formation from Surface \\ Thickness of Pay Zone \\ Type of Pay zone \\ PVT Properties \\ - API Gravity \\ Separator \\ Reservoir \\ Viscosity at Reservoir conditions
}

\author{
Bubble Point Pressure \\ Viscosity at \\ Formation Conditions \\ Oil Formation \\ Volume Factor \\ Gas Formation \\ volume Factor
}

\section{Crude Oil Summary - Bureau of Mines Classification}

Gravity, API

Specific Gravity, 60/60F Distillation

IBP

5 PCT Vol Recovered

10

20

30

40

50

60

70

Fraction 400-500F, PCT Vol Gravity, API

Mercaptan Sulfur, PPM

Flash Point, $F$, (TAG)

Pour Point, F, (upper)

Viscosity

Kinematic, 60F $(15.6 \mathrm{C}), \mathrm{CS}$

$100 \mathrm{~F}(37.8 \mathrm{C}), \mathrm{CS}$

$130 \mathrm{~F}(54.4 \mathrm{C}), \mathrm{CS}$
Carbon Residue, PCT WT (CCR)

Aniline Point, ${ }^{\circ} \mathrm{F}$

Sulfur, PCT WT

Hydrogen Sulfide, PPM

Neutralization No., Total Acid

Water and Sediment, PCT VOI

Salt content, pounds/1000B

Reid Vapor Pressure, pounds

Nitrogen, Total, PPM

Nickel, PPM

Vanadium, PPM

Ash, PPM

Carbon, Pct Wt

Hydrogen, Pct wit

Carbon/Hydrogen Ratio

Distillation Summary Gasoline-Naphtha, IBP $-392^{\circ} \mathrm{F}$, \& Vol

Kerosine, $392-527^{\circ} \mathrm{F}$

Iight Gas Oil, $527-690^{\circ} \mathrm{F}$

Heavy Gas Oil, $690-790^{\circ} \mathrm{F}$

Residuum, $790^{\circ} \mathrm{F}^{+}$ 
2.3

Resources and Reserves of Heavy Oils

2.3.1 Definitions

Estimating the amount of oil contained in the united States is a difficult task because not all of the oil present in the ground can be economically produced. Accordingly, at least two numbers need to be considered:

- Resource Quantity - The total stock-tank volume of heavy oil and tar sand remaining in a reservoir, without regard to technologic or economic feasibility of recovery.

- Proved Reserve Quantity - That part of the heavy oil or tar sand that can be recovered under existing economic and operating conditions in a given year.

Another term often used is "Potential Reserve," which represents that part of a resource that could become proved reserve using enhanced recovery operations (e.g., steam stimulation).

The significance of the distinctions between the various definitions becomes clear when one considers some recent, welldocumented studies of the oil found in Canada.12 The in-place resources of Alberta are presently estimated as $2601 \times 109$ barrels* of heavy oil and tar sand. By contrast, the proved recoverable reserves are estimated to be between 157 and $472 \times 10^{9}$ barrels.

${ }^{12}$ C.D. Outtrim and R.G. Evans, "Alberta's Oil Sand Reserves and Their Evaluation," presented at the 157 th Meeting of CIM, Canada-Venezuela oil Sands Symposium, Edmonton, Alberta, May 1977.

* In this chapter, all resources are reported in units of billions of barrels. To put this in perspective, $1 \times 10^{9}$ barrels represents a volume the size of a football field $22 \mathrm{mi}$.high. The United States presently consumes over 5 billion barrels of oil each year. 


\subsubsection{Resources of Heavy Oils and Tar Sands}

The occurrences, quantity of resources, and historical uses of asphaltites and asphalts have been described in detail. 5 Tar sands etc. and extractable bitumens $(<12$ API) of the world have been extensively surveyed $3,4,6,9,12-18$ and the reader is referred to these papers for detailed information. More recently, workers at the Laramie Energy Technology Center have surveyed the tar sands resources of the United States. Figure 2.3.2-I indicates the location of U.S. tar sands and Table 2.3.2-1 provides the latest estimates of the in-place resources of tar sands in the U.S. Figure 2.3.2-1 should be compared with earlier surveys. which included all accumulations of oil in shallow deposits. Figure 2.3.2-2 represents a superimposition of two such earlier surveys conducted by the U.S. Department of Interior. 3,15 These earlier reports showed more extensive deposits, although some of these resources were undoubtedly heavy oils rather than tar sands as now defined.

${ }^{13} \mathrm{~V} . \mathrm{A}$. Kuuskraa, S. Chalton and T.M. Doscher, "The Economic Potential of Domestic Tar Sands," DOE Contract Number 9014-018-021-22004, Washington, D.C., 1978.

${ }^{14}$ C.A. Koch, "Oil Resources in Tar Sand Deposits in the United States," DOE Order Number DE-AP-20-80LC01022, Washington, D.C.

15 Ball Associates, Itd., "Surface and Shallow Oil-Impregnated Rocks and Shallow Oil Fields in the United states," U.S. Dept, of Interior, Bureau of Mines, Monograph 12 , Washington, D.C., 1965 .

${ }^{16}$ D. Ball, "United States Tar Sands as a Petroleum Source", Paper presented at the symposium "An Assessment of some Factors Affecting the Availability of Oil and Gas in the United States through 1980," U.S. Dept. of Interior, Washington, D.C., March 1967.

$17_{H}$. R. Ritzma, "Oil Impregnated Sandstone Deposits of Utah - A Progress Report," Interstate Oil Compact Comm. Bull. II, No. 2, 24-34 (December 1969).

${ }^{18}$ H. R. Ritzma, "Location Map and Oil Impregnated Rock Deposits of Utah," Utah Geological and Mineralogical Survey, Map No. 33, Salt Lake City, Utah, April 1973. 


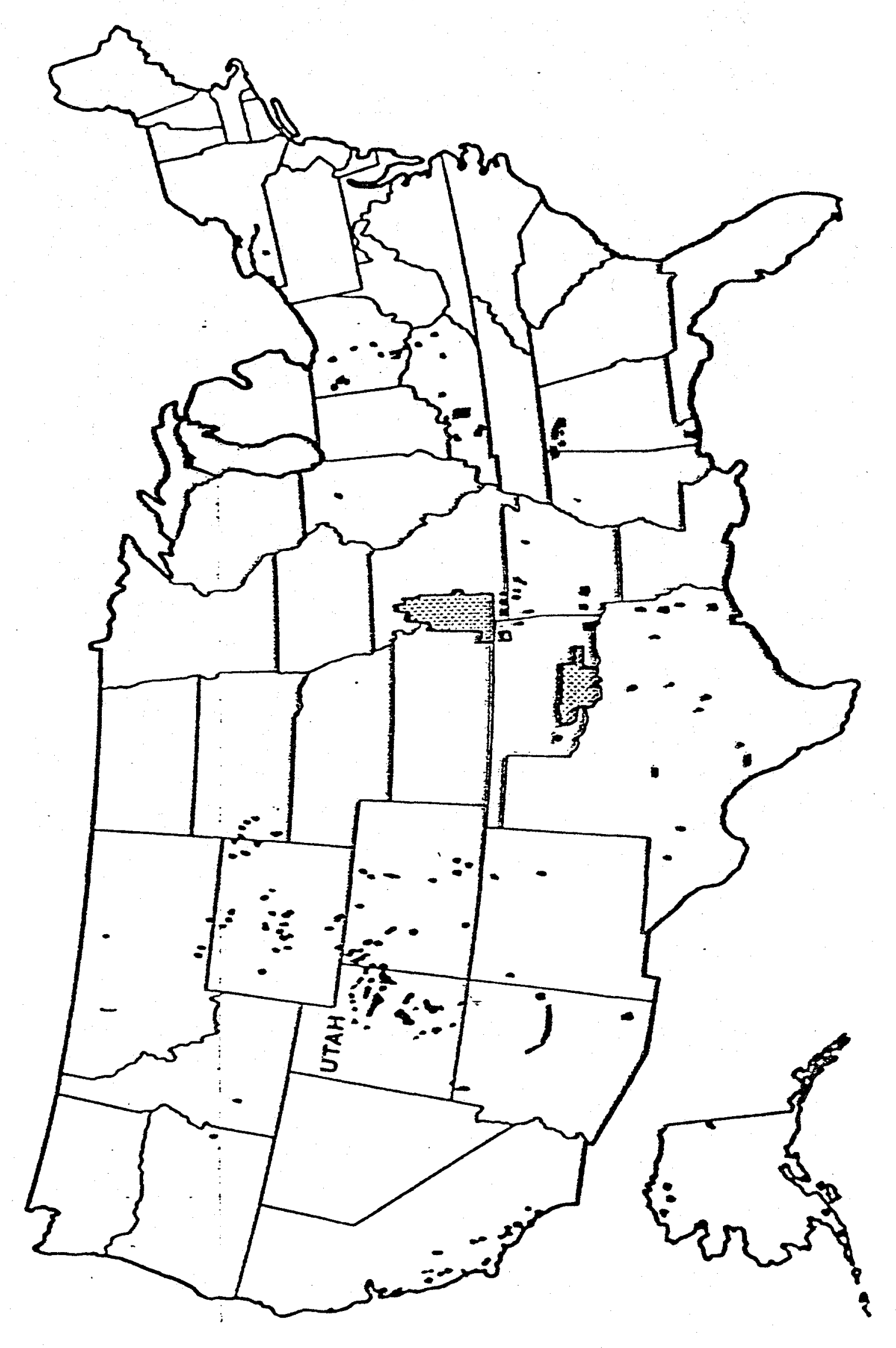


Table 2.3.2-1 Deposits of bitumen-bearing rocks in the U.S. with resources over $1,000,000$ barrels; prepared by workers at LETC, Laramie, Wyoming.

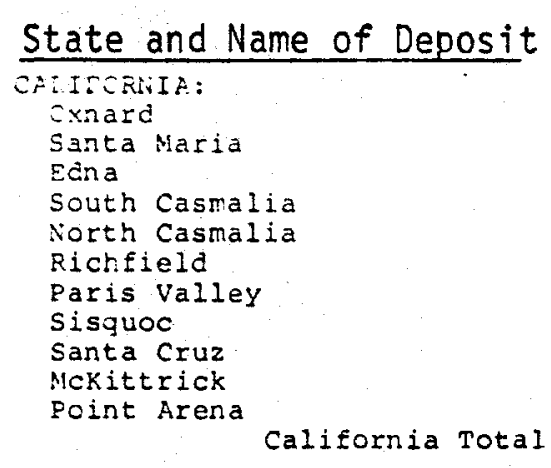

Estimated Resources (Billions of Barrels)

KENTUCKY :

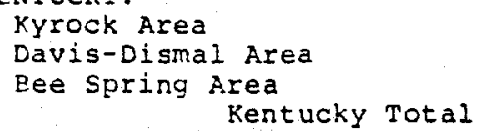

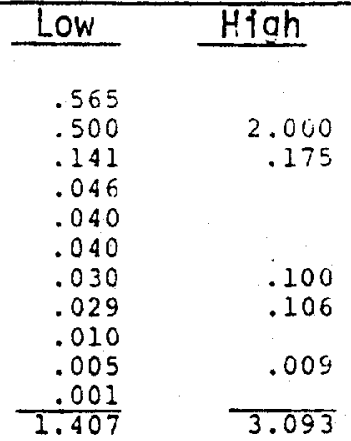

$\begin{array}{ll}.018 & \\ .007 & .011 \\ .008 & .037 \\ .003 & .600 \\ .057 & 3.000\end{array}$

$\begin{array}{rr}12.504 & 16.004 \\ 4.000 & 4.500 \\ 3.500 & 4.000 \\ 1.000 & 1.507 \\ 1.000 & 1.200 \\ .300 & 1.160 \\ .385 & .470 \\ .100 & .125 \\ .075 & .100 \\ .065 & .125 \\ .060 & .075 \\ .050 & .075 \\ .025 & .030 \\ .020 & .025 \\ .012 & .015 \\ .012 & .015 \\ .010 & .015 \\ .010 & .015 \\ .010 & .012 \\ .007 & .010 \\ .005 & .010 \\ .008 & .008 \\ .002 & .006 \\ .001 & .005 \\ .002 & .003 \\ .002 & .002 \\ .001 & .001 \\ 23.166 & 29.513 \\ 24.787 & 36.243 \\ & \end{array}$




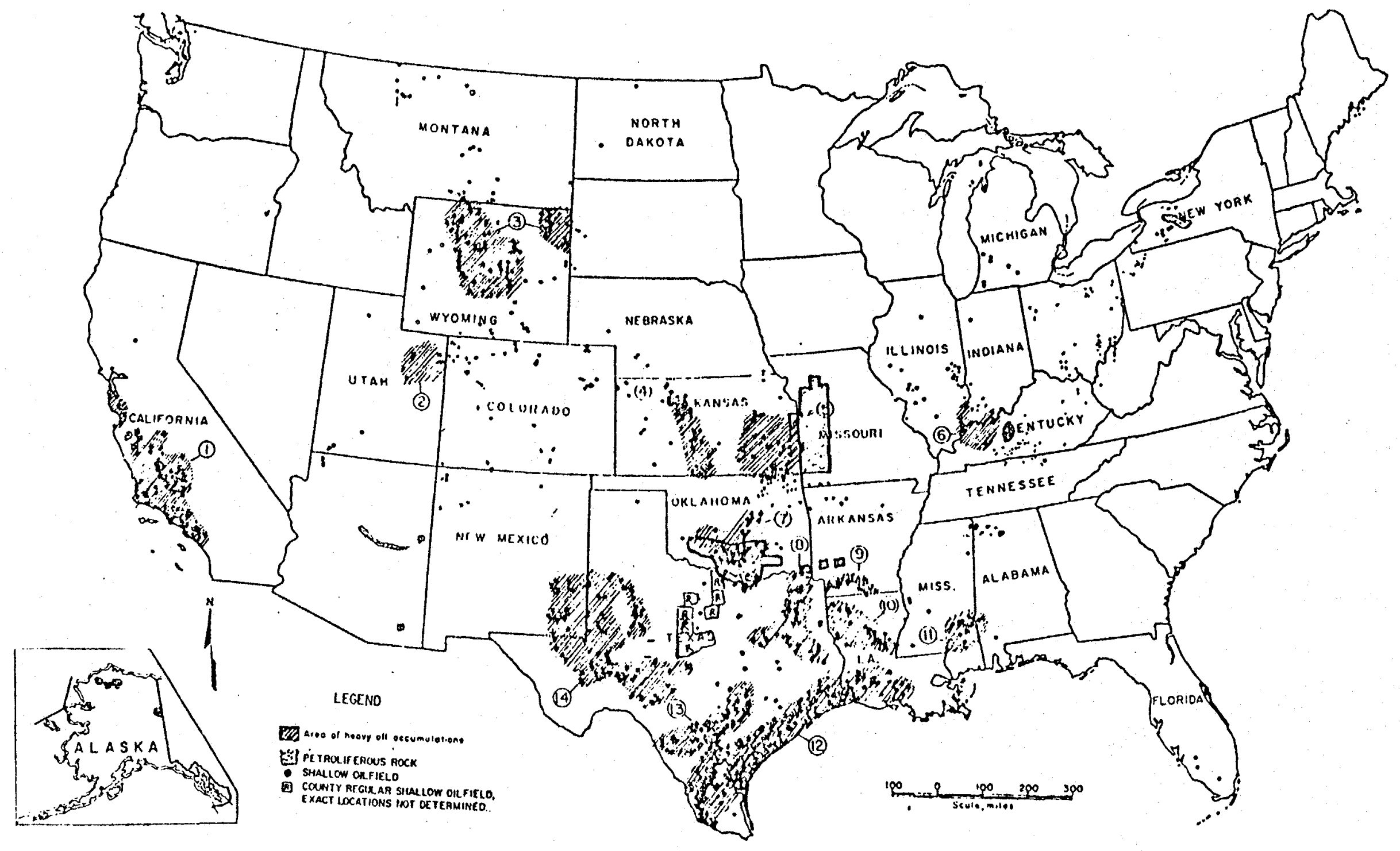

Fig. 2.3.2-2 Geographical location of heavy oil fields in the Inited States. This map illustrates the superposition of data from two reports (Refs. 3\&15), which included information on heavy crude fields, heavy oil accumulations, and petroliferous rocks. Deposits in Wyoming, Oklahoma, and Kansas, although large in areal extent, are disperse. Major deposits having high local concentrations of heavy ofls occur in Utah and California. 
Resource estimates of heavy crudes are much less definitive. Heavy crudes are of particular interest, however, in that some primary production (10\%) is possible with these materials and large amounts are presently being produced by thermal stimulation techniques. Such crudes represent a larger fraction of the U.S. Oil resource than tar sands. A survey of crudes of <25 API with some mobility in place was conducted in 1966 by the U.S. Bureau of Mines. 4 This survey further classified the resources with respect to ease of recovery as follows:

\section{Class 1 - Desirable characteristics for thermal recovery operations -- sandstone reservoirs at depths of less than 3,000 feet, greater than 10 feet thickness, stock tank oil saturations of $750 \mathrm{bbl} / \mathrm{acre}$-ft or greater, viscosity of oil sufficient for mobility at existing conditions. \\ Class 2 - Some of the above desirable charac- teristics, but not all. \\ Class 3 - Only a few of the above desirable characteristics.}

For the purpose of this chapter, we have considered only those crudes with API gravities $<20$. Accordingly, the locations of known resources of heavy crudes of the U.S. are shown in Fig. 2.3.2-3, and their ease of production is indicated in Table 2.3.2-2. As can be seen from the table, about 55.5 billion barrels of heavy crude ( 20 API) were in place in 1966. Had we chosen crudes <25 API, the estimate would have been much larger ( 106.8 billion barrels).

Magnitudes for the resources of heavy oils and tar sands of Kansas-Missouri-oklahoma have fluctuated dramatically in the past few years. Estimates as high as 100 billion bbl 


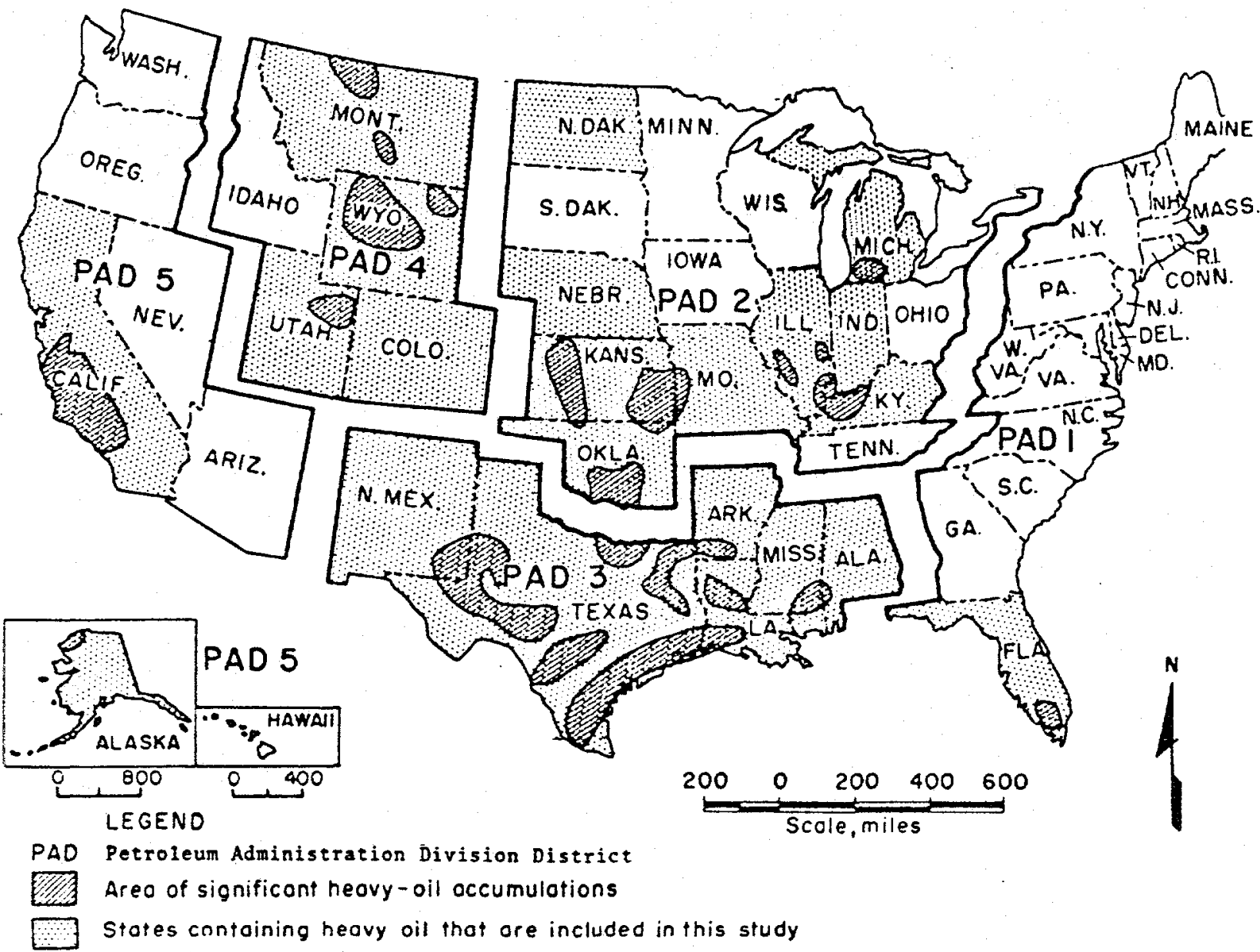

Fig. 2.3.2-3 States containing heavy crude oil included in this study. 
Table 2.3.2-2 United States heavy crude oil resources (less than $20^{\circ}$ API with some mobility ${ }^{4}$ ).

\begin{tabular}{|c|c|c|c|c|c|}
\hline \multirow{2}{*}{$\begin{array}{c}\text { PAD } \\
\text { district }\end{array}$} & \multirow[b]{2}{*}{ Location } & \multirow{2}{*}{$\begin{array}{l}1965 \text { estimate of } \\
\text { oil-in-place, } \\
\text { billions of bbl }\end{array}$} & \multicolumn{3}{|c|}{ Resources by class } \\
\hline & & & Class 1 & Class 2 & Class 3 \\
\hline 1 & $\begin{array}{l}\text { East Coast } \\
\text { (mostly Florida) }\end{array}$ & 0 & 0 & 0 & 0 \\
\hline 2 & Illinois & 0.0003 & 0.0003 & 0 & 0 \\
\hline 2 & Indiana & 0.0102 & 0 & 0 & 0.0102 \\
\hline 2 & Kansas & 0.0002 & 0 & 0 & 0.0002 \\
\hline 2 & Michigan & 0.0010 & & & \\
\hline 2 & Oklahoma & 0.472 & 0.039 & 0.035 & 0.398 \\
\hline 3 & Alabama-Miss issippi & 4.548 & 3.919 & 0.612 & 0.017 \\
\hline 3 & Louisiana & 0.486 & 0.384 & 0.032 & 0.070 \\
\hline 3 & New Mexico & 0.051 & 0 & 0 & 0.041 \\
\hline 3 & Texas & 10.310 & 0.670 & 2.730 & 6.910 \\
\hline 4 & Colorado & 0.010 & 0 & 0 & 0.010 \\
\hline 4 & Montana & 0.010 & 0.005 & 0.001 & 0.003 \\
\hline 4 & Utah & 0.633 & 0.616 & 0 & 0.017 \\
\hline 4 & Wyoming & 1.032 & 0.752 & 0.270 & 0.010 \\
\hline 5 & California & 36.339 & 29.010 & 3.656 & 3.673 \\
\hline 5 & Alaska & 0.013 & & & \\
\hline & TOTAL: & 55.546 & 35.396 & 8.734 & 11.416 \\
\hline
\end{tabular}


of oil have been made. 19 However, recent estimates by each state's geological survey office have tended to be much less optimistic.

Evaluation of heavy oil and tar sands in Bourbon, Crawford and Cherokee Counties, Kansas, by the Kansas Geological survey, December 1977, has indicated a resource base of 0.200-0.225 billion barrels of oil-in-place, none of which is recoverable under 1977 existing technology and economics. The estimates of resource size are severely downgraded from earlier estimates due to discontinuous nature, thinness and shaliness of the reservoir sandstone bodies. 20

An evaluation of the heavy oil potential of northeastern Craig and northwestern ottawa counties, Oklahoma, by the Oklahoma Geological survey, June 1979, concludes that insignificant quantities of heavy oil are present. 21

An inventory of heavy oil in western Missouri, by the Missouri Department of Natural Resources, Division of Geology and Survey, september 1979, estimates that a resource of 1.4 to 1.9 billion barrels of oil-in-place is present, none of which is considered in a reserve category under present economics and technological parameters. 22

Many heavy oil reservoirs are presently being produced using thermal techniques. A recent summary of U.S. thermal projects is provided in Table 2.3.2-3.23 A similar list can be found in Ref. 4. Table 2.3.2-4 provides some additional data on the production of heavy crudes. The total U.S. Ieserves estimated in 1975 were 2.6 billion barrels. 24

${ }^{19}$ R.T. Johansen, "Chemical and Physical Principles of Enhanced Recovery Processes," presented at the Fossil Fuel and Energy co Conf. (CONFAB), Saratoga, Wyoming, July 1977.

20 BETC Publicatión \#RI-77/20, Bartlesville, Oklahoma, December 211977 .

21 BETC Publication \#1812-1, DOE \#ET-76-S-031812, Bart1esvil1e, 22 Oklahoma, June, 1979.

22 BETC Pubication \#1808-1, DOE \#ET-76-S-03-1808, Bartlesville, 23 Oklahoma, September 1979 .

230 il and Gas J. 74, 107 (Apri1 5, 1976).

24 International petroleum Encyclopedia 1975, Petroleum Publishing Company, Tulsa, Oklahoma, 1975. 
Table 2.3.2-3 Thermal recovery projects in the United States (Ref. 23).

\begin{tabular}{|c|c|c|c|c|c|c|c|c|c|c|c|c|c|c|c|c|c|c|c|c|c|}
\hline never & $\sin x$ & ondy & operarer & Stint & Aven & More & athitit & $\operatorname{mon}^{\circ}$ & Pusuly. & ints: & mon. & Nor & ater & et. & nerriogs & 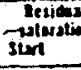 & Dis & $\begin{array}{l}\text { Prepect } \\
\text { metery }\end{array}$ & Kofers & Prokess & momatas \\
\hline 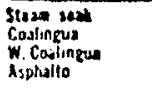 & 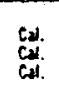 & 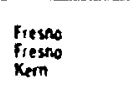 & $\begin{array}{l}\text { ssell } \\
\text { socell } \\
\text { cetty }\end{array}$ & $\begin{array}{l}2162 \\
3 / 65 \\
3 / 75\end{array}$ & $\begin{array}{c}2.520 \\
1.280 \\
1.20\end{array}$ & 385 & & 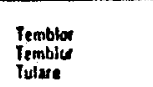 & $\begin{array}{l}\mathbf{2 a} \\
\mathbf{3} \\
\mathbf{3 1}\end{array}$ & $\begin{array}{l}1.000 \\
400 \\
150\end{array}$ & $\begin{array}{l}\frac{900.8,800}{1200} \\
1,000\end{array}$ & $\mathfrak{l i n}_{12}^{1612}$ & $\begin{array}{l}200554 \\
700 \\
1217\end{array}$ & 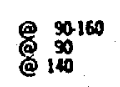 & $\begin{array}{l}\text { Prim. } \\
\text { prim. } \\
\text { primian. }\end{array}$ & $\begin{array}{l}89 \\
85 \\
100\end{array}$ & $\begin{array}{l}69 \\
75 \\
\text { is }\end{array}$ & 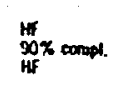 & $\begin{array}{l}3.900 \\
100\end{array}$ & $\begin{array}{l}\text { suce. } \\
\text { Sect } \\
\text { Iitn }\end{array}$ & $\begin{array}{l}\text { Yres } \\
\text { res }\end{array}$ \\
\hline 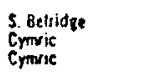 & 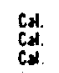 & 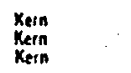 & $\begin{array}{l}\text { ucculloch } \\
\text { Geflus } \\
\text { Gunl }\end{array}$ & $\begin{array}{l}700 \\
1,68 \\
6 / 66\end{array}$ & ${ }_{70}^{100}$ & ${ }_{8}^{2}$ & & 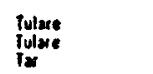 & 25 & $\begin{array}{l}1.000 \\
8.000\end{array}$ & $\begin{array}{l}8000 \\
1,000 \\
1,000\end{array}$ & $\begin{array}{l}12 \\
12 \\
10\end{array}$ & 2.74 & @ 100 & Prite. & $\underset{95}{\infty}$ & $\begin{array}{l}80 \\
85\end{array}$ & 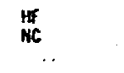 & 500 & $\begin{array}{l}\text { Prom. } \\
\text { Suece. } \\
\text { Surce }\end{array}$ & 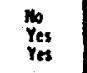 \\
\hline 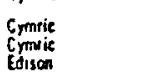 & 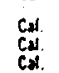 & 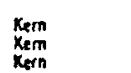 & 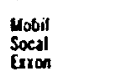 & $\begin{array}{l}3 / 65 \\
66 \\
65\end{array}$ & $\begin{array}{r}170 \\
7.00 \\
1.100\end{array}$ & $\begin{array}{l}46 \\
75\end{array}$ & & 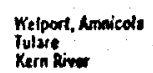 & $\begin{array}{l}38 \\
\mathbf{3 5} \\
\mathbf{3 0}\end{array}$ & $\begin{array}{l}3.000 \\
1.000 \\
2,000\end{array}$ & 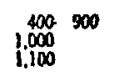 & 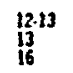 & $310^{\frac{1.54}{2.44}}$ & 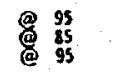 & 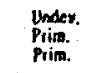 & $\stackrel{99}{90}$ & 75 & 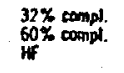 & $\begin{array}{l}400 \\
600\end{array}$ & $\begin{array}{l}\text { Sunce } \\
\text { suox }\end{array}$ & $\begin{array}{l}\text { Yes } \\
\text { Yes }\end{array}$ \\
\hline 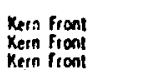 & 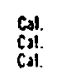 & 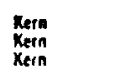 & $\begin{array}{l}\text { ARco } \\
\text { Gefut } \\
\text { Mobil }\end{array}$ & 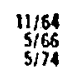 & $\begin{array}{r}160 \\
1.080 \\
6000\end{array}$ & $\begin{array}{l}55 \\
32 \\
100\end{array}$ & & 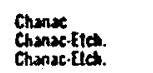 & $\begin{array}{l}32 \\
30.4 \\
31\end{array}$ & $\begin{array}{l}1.600 \\
1,500 \\
i, 000\end{array}$ & $\begin{array}{l}1.600 \\
2.300 \\
1,2000\end{array}$ & $\begin{array}{l}13.7 \\
13.5 \\
11.4\end{array}$ & $\begin{array}{l}400 \\
806 \\
800\end{array}$ & 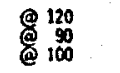 & $\begin{array}{l}\text { Prim. } \\
\text { Pritim } \\
\text { Prim. }\end{array}$ & 8 & $\not i$ & 梦 & 1.676 & $\begin{array}{l}\text { Sutce } \\
\text { sutec. }\end{array}$ & $\begin{array}{l}\text { Yes } \\
\text { Yess }\end{array}$ \\
\hline 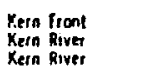 & 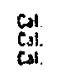 & 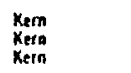 & $\begin{array}{l}\text { Socal } \\
\text { chans . West. } \\
\text { Cettly }\end{array}$ & $\begin{array}{l}70 \\
3 / 68 \\
60\end{array}$ & $\begin{array}{r}640 \\
240 \\
3,000\end{array}$ & $1271^{\prime}$ & & 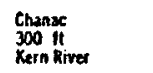 & $\begin{array}{l}27 \\
39\end{array}$ & $\begin{array}{r}700 \\
4.000 \\
3.000\end{array}$ & $\begin{array}{c}2.400 \\
1900-800 \\
900\end{array}$ & $\begin{array}{l}12 \\
13.5 \\
13.5\end{array}$ & $\begin{array}{l}\text { at } \\
\text { alu } \\
\text { alu }\end{array}$ & $\begin{array}{l}\text { @.110 } \\
\text { @ } 90\end{array}$ & $\begin{array}{l}\text { Prim: } \\
\text { Priva: } \\
\text { Prim. }\end{array}$ & $\begin{array}{l}80 \\
80 \\
90\end{array}$ & $\begin{array}{l}75 \\
30 \\
86\end{array}$ & $\begin{array}{l}75 \% \text { compl. } \\
M C\end{array}$ & $\begin{array}{l}900 \\
11,588\end{array}$ & $\begin{array}{l}\text { Suce. } \\
\text { Suluce. } \\
\text { Sulec. }\end{array}$ & 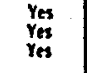 \\
\hline 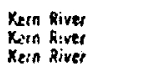 & 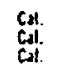 & 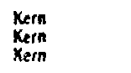 & $\begin{array}{l}\text { cetely } \\
\text { stril } \\
\text { sorat }\end{array}$ & $\begin{array}{r}74 \\
4 / 63 \\
65\end{array}$ & $\begin{array}{l}1.300^{9} \\
1.4000\end{array}$ & 43 & & $\begin{array}{l}\text { Kern River } \\
\text { Kenn Rever } \\
\text { Kern River }\end{array}$ & 319 & $\begin{array}{l}3.000 \\
2.000 \\
2.000\end{array}$ & 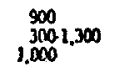 & $\underset{13.5}{13.13}$ & 4lus & 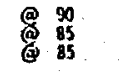 & $\begin{array}{l}\text { Prim. } \\
\text { Primit: } \\
\text { Primen: }\end{array}$ & $\begin{array}{l}86 \\
90 \\
95\end{array}$ & $\begin{array}{r}76 \\
.73 \\
\cdot 78\end{array}$ & 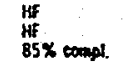 & 9,000 & $\begin{array}{l}\text { Promet. } \\
\text { Sutect. } \\
\text { Suce. }\end{array}$ & 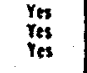 \\
\hline 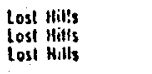 & 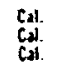 & 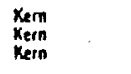 & $\begin{array}{l}\text { Aeco } \\
\text { befily } \\
\text { Guif }\end{array}$ & $\begin{array}{l}5 / 67 \\
1 / 68 \\
8 / 64\end{array}$ & $\begin{array}{l}15 \\
150\end{array}$ & $\begin{array}{l}7 \\
61 \\
43\end{array}$ & & 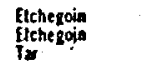 & $\frac{32}{33}$ & 年, & $\begin{array}{l}5500 \\
5500.400 \\
200.4\end{array}$ & $\begin{array}{l}12.5 \\
13 \\
16\end{array}$ & 粱 & 送 1000 & 舅rim. & 90 & 80 & $\underset{w}{m}$ & 500 & $\begin{array}{l}\text { Suce } \\
\text { Succe } \\
\text { Sulce. }\end{array}$ & 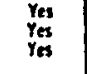 \\
\hline 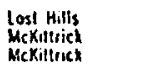 & $\begin{array}{l}c a d . \\
c \\
c a d . \\
c a l\end{array}$ & 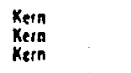 & $\begin{array}{l}\text { cull } \\
\text { cetry } \\
\text { celty }\end{array}$ & $\begin{array}{l}2175 \\
6,47\end{array}$ & $\mathbf{s p o s}_{3}^{1}$ & 3 & 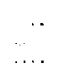 & 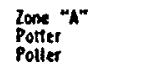 & $\begin{array}{l}30 \\
30\end{array}$ & $\begin{array}{l}3.000 \\
3.000\end{array}$ & $\begin{array}{l}700 \\
1,200 \\
1,200\end{array}$ & $\begin{array}{l}\text { is } \\
\text { is } \\
\text { is }\end{array}$ & $\underbrace{\infty \infty 00}_{\infty \infty \infty}$ & 置1000 & 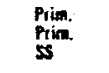 & 75 & $\begin{array}{l}52 \\
65\end{array}$ & $\mathbb{w}^{\mathbf{s}}$ & 7,500 & $\begin{array}{l}\text { IIm } \\
\text { succ. } \\
\text { bisc }\end{array}$ & 象 \\
\hline 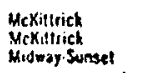 & 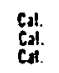 & 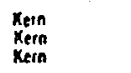 & $\begin{array}{l}\text { accidentad } \\
\text { soct } \\
\text { AREC }\end{array}$ & $\begin{array}{l}4 / 65 \\
9 / 63 \\
9 / 63\end{array}$ & $\begin{array}{r}46 \\
1.000\end{array}$ & 216 & & 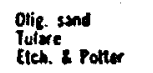 & $\begin{array}{l}31 \\
35 \\
30\end{array}$ & $\begin{array}{r}2.000 \\
1.3000\end{array}$ & $\begin{array}{l}300 \\
280 \\
1,0002,500\end{array}$ & $\begin{array}{l}14 \\
15 \\
12 \cdot 21\end{array}$ & 2002000 & 8100 & $\begin{array}{l}\text { Prim. } \\
\text { Prie: } \\
\text { Prime }\end{array}$ & 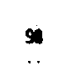 & 75 & sox conpt. & & $\begin{array}{l}\text { surce. } \\
\text { Susce. } \\
\text { Suree }\end{array}$ & 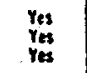 \\
\hline 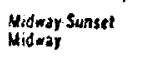 & $\begin{array}{l}c \text { cal. } \\
\text { cad. }\end{array}$ & $\begin{array}{l}X_{\text {Xen }} \\
\text { Keft }\end{array}$ & $\begin{array}{l}\text { Chans:-West. } \\
\text { Gettly }\end{array}$ & $\frac{3 / 64}{6 / 64}$ & $\begin{array}{l}1.970 \\
215\end{array}$ & 21 & $\ldots$ & 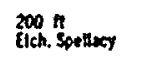 & 30 & $\begin{array}{l}1.500 \\
2.000\end{array}$ & $\begin{array}{r}1001.1000 \\
850+ \\
.500\end{array}$ & ${ }_{13.5}^{p}$ & $7 \mathrm{ss}^{4}$ & 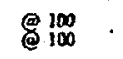 & $\begin{array}{l}\text { Pire. } \\
\text { Prim. }\end{array}$ & ม็ & 90 & $\mathbf{F}$ & 20,0000 & $\begin{array}{l}\text { Suace } \\
\text { Sure }\end{array}$ & $y_{n \in S}$ \\
\hline Mitway & cal & Ken & Getty & $9 / 64$ & 125 & $n$ & & Ponter & 3s & 2,000 & 1,200 & 14 & 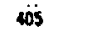 & (@) 100 & Pim. & 69 & 51 & $\mathbf{H}$ & 2.100 & sece & yes \\
\hline 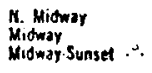 & $\begin{array}{l}c a d . \\
c a d . \\
c 2 d\end{array}$ & 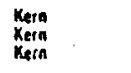 & 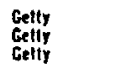 & $\frac{11 / 64}{1 / 175}$ & $\begin{array}{l}135 \\
36 \\
35\end{array}$ & $\begin{array}{l}70 \\
16 \\
46\end{array}$ & & $\begin{array}{l}\text { Potter } \\
\text { Pothet A.PC } \\
\text { Polter }\end{array}$ & $\begin{array}{l}33 \\
32 \\
32\end{array}$ & $\begin{array}{l}2.500 \\
2.000 \\
2.000\end{array}$ & $\begin{array}{l}1.400 \\
1.000 \\
1.000\end{array}$ & $\begin{array}{l}13.4 \\
11 \\
12\end{array}$ & 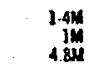 & 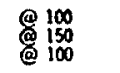 & $\begin{array}{l}\text { Prime. } \\
\text { Pritu: } \\
\text { Primo }\end{array}$ & $\begin{array}{l}91 \\
98 \\
82\end{array}$ & $\begin{array}{l}81 \\
91 \\
53\end{array}$ & 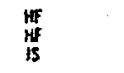 & $\begin{array}{l}1.800 \\
2,150\end{array}$ & $\begin{array}{l}\text { Suce. } \\
\text { suce. } \\
\text { suce. }\end{array}$ & $\begin{array}{c}\text { Yres } \\
\text { res } \\
\text { res }\end{array}$ \\
\hline 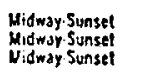 & $\begin{array}{l}c a 1 . \\
c \text { cal } \\
c a 1 .\end{array}$ & 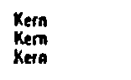 & $\begin{array}{l}\text { Mobiu } \\
\text { Mobiul } \\
\text { Hoculloch }\end{array}$ & $\begin{array}{l}1 / 67 \\
10 / 77^{7} \\
65\end{array}$ & $\begin{array}{l}350 \\
350 \\
60\end{array}$ & $\begin{array}{l}200 \\
50 \\
117\end{array}$ & $:$ & $\begin{array}{l}\text { Poter } \\
\text { suonsect } \\
\text { Pofter }\end{array}$ & $\begin{array}{l}335 \\
34 \\
25\end{array}$ & $\begin{array}{l}1.000 \\
4.000 \\
2.000\end{array}$ & $\begin{array}{l}1,000 \\
.500 \\
1,100\end{array}$ & $1_{1.2}^{13.5}$ & ${ }_{800}^{24}$ & $\begin{array}{l}800 \\
850\end{array}$ & $\begin{array}{l}\text { Prim. } \\
\text { prim. } \\
\text { Prim. }\end{array}$ & $\begin{array}{l}85 \\
95 \\
75\end{array}$ & $\begin{array}{l}70 \\
81 \\
60\end{array}$ & 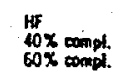 & $\begin{array}{l}3.500 \\
3.504 \\
3.000\end{array}$ & suec & ist. \\
\hline 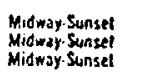 & 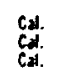 & 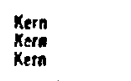 & $\begin{array}{l}\text { occiontst } \\
\text { sheil } \\
\text { scodi }\end{array}$ & $\underset{65}{91 / 64}$ & $\begin{array}{l}233 \\
565 \\
160\end{array}$ & 500 & & $\begin{array}{l}\text { Monsect } \\
\text { potiter } \\
\text { Pofiter }\end{array}$ & $\underset{36}{33}$ & $\begin{array}{l}2,400 \\
2,000 \\
1.300\end{array}$ & $\begin{array}{l}1,000 \\
1,2001.9000 \\
1,200\end{array}$ & $\begin{array}{l}12.6 \\
1.04 \\
1.14\end{array}$ & 2.4.5. & $\mathbb{1}_{100}^{801000}$ & $\begin{array}{l}\text { prian. } \\
\text { prime. } \\
\text { rime. }\end{array}$ & 85 & 70 & $\underset{\substack{W \\
\text { W }}}{\mathbb{N}}$ & 9.000 & $\begin{array}{l}\text { surec } \\
\text { suce } \\
\text { suree }\end{array}$ & 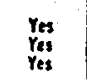 \\
\hline 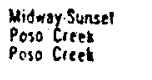 & 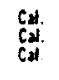 & 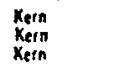 & 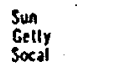 & 94 & $\begin{array}{l}226 \\
84 \\
240\end{array}$ & 198 & enlic & 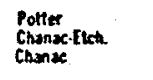 & $\begin{array}{l}35 \\
32,2 \\
212\end{array}$ & $\begin{array}{l}\frac{1.000+}{1,3000} \\
1,500\end{array}$ & $\begin{array}{l}1,0001,500 \\
2,000 \\
2,500\end{array}$ & 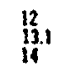 & , ili & 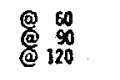 & $\begin{array}{l}\text { Prim. } \\
\text { prim } \\
\text { Prime }\end{array}$ & $\begin{array}{l}90 \\
82\end{array}$ & $\begin{array}{l}50 \\
76 \\
86\end{array}$ & 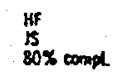 & 4,1200 & $\begin{array}{l}\text { Suck. } \\
\text { IIIIf } \\
\text { suece }\end{array}$ & $\begin{array}{l}\text { ress } \\
\text { ress }\end{array}$ \\
\hline 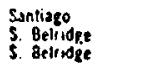 & $\begin{array}{l}c=1 \\
c=1 \\
c a t \\
c a l\end{array}$ & 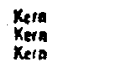 & $\begin{array}{l}\text { Cuit } \\
\text { Socal } \\
\text { woccullow }\end{array}$ & $\begin{array}{r}1 / 65 \\
66 \\
70\end{array}$ & $\begin{array}{l}150 \\
100\end{array}$ & ${ }_{40}^{11}$ & & 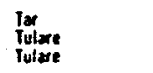 & 315 & $\begin{array}{l}2,000 \\
1,000\end{array}$ & $\begin{array}{l}550,1250 \\
5500,230 \\
800\end{array}$ & $\mathbb{1 i}_{12}$ & & 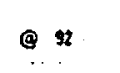 & 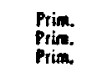 & 85 & $\begin{array}{l}30 \\
40\end{array}$ & $*$ & 150 & $\begin{array}{l}\text { Succ: } \\
\text { susc: } \\
\text { Prome }\end{array}$ & 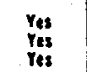 \\
\hline 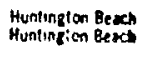 & $c$ & $\begin{array}{l}\text { oimue } \\
\text { orange }\end{array}$ & $\begin{array}{l}\text { Burmanh } \\
\text { Burmuth }\end{array}$ & 64 & 500 & $46^{9}$ & $:$ & $\frac{7 x}{n x}$ & 35 & 1.000 & $\begin{array}{l}2.800 \\
2.000\end{array}$ & 13 & 78 & 8125 & $\begin{array}{l}\text { Priman } \\
\text { Primary }\end{array}$ & 95 & $\begin{array}{l}70 \\
80\end{array}$ & 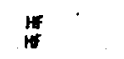 & $\begin{array}{l}200 \\
1.500\end{array}$ & sucec & $\begin{array}{l}\text { Yest } \\
\text { Yes }\end{array}$ \\
\hline 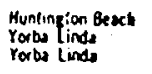 & $\begin{array}{l}c \text { ca. } \\
\text { cad. } \\
\text { cad. }\end{array}$ & 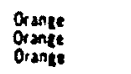 & $\begin{array}{l}\text { soat } \\
\text { cout } \\
\text { shely }\end{array}$ & $\begin{array}{l}1 / 65 \\
10162 \\
3 / 61\end{array}$ & $\begin{array}{l}300 \\
100\end{array}$ & 200 & 23 & 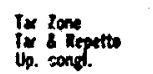 & 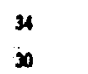 & $\begin{array}{r}2,000 \\
600\end{array}$ & $\begin{array}{l}2,000 \\
200020000 \\
200.200 \\
400\end{array}$ & $\begin{array}{l}127 \\
12 \\
12\end{array}$ & ${ }^{2 m} .4 \mathrm{M}$ & $\begin{array}{l}140 \\
\text { (1) } 85\end{array}$ & 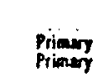 & $\$$ & $\begin{array}{l}50 \\
50\end{array}$ & $60 x \mathrm{comph}$ & 8.500 & $\begin{array}{l}\text { Surce. } \\
\text { suce. } \\
\text { Susce. }\end{array}$ & 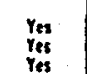 \\
\hline 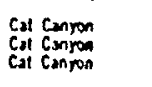 & c.t. & 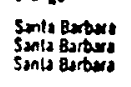 & 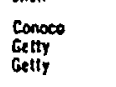 & $\begin{array}{l}63 \\
64 \\
65\end{array}$ & $\begin{array}{l}.550 \\
\substack{1.500 \\
300}\end{array}$ & $\begin{array}{l}130 \\
100 \\
13 \\
13\end{array}$ & $:$ & 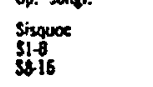 & $\begin{array}{l}30 \\
330 \\
30\end{array}$ & $\begin{array}{l}1,200 \\
1,500 \\
3,000\end{array}$ & $\begin{array}{l}3.000 \\
2300 \\
3.000\end{array}$ & $\begin{array}{l}10 \\
10 \\
12 \\
12\end{array}$ & 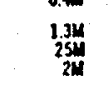 & 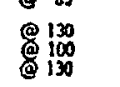 & 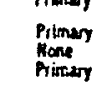 & 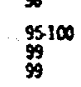 & $\begin{array}{l}30 \\
{ }_{15}^{85}\end{array}$ & wif & 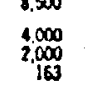 & $\begin{array}{l}\text { sock. } \\
\text { sucke. } \\
\text { suctec }\end{array}$ & 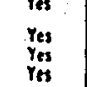 \\
\hline 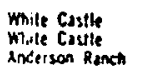 & $\underset{\substack{\mathbf{u} \\
\text { Ter. }}}{\mathbf{u}}$ & 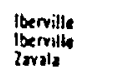 & $\begin{array}{l}\text { Shell } \\
\text { stitil } \\
\text { tronon }\end{array}$ & $\begin{array}{l}11 / 76 \\
3775 \\
1 / 74\end{array}$ & $\begin{array}{l}37 \\
37 \\
2\end{array}$ & $i_{i}^{2}$ & 1 & $\mathfrak{y}^{0}$ & $\underbrace{\infty}_{30}$ & $\begin{array}{l}5.000 \\
5.000 \\
5000\end{array}$ & $\begin{array}{l}i, 350 \\
i, 000 \\
525\end{array}$ & $\underset{36}{16}$ & ${ }_{1,14}^{500}$ & 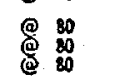 & 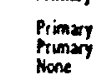 & 9 & $\begin{array}{l}50 \\
50\end{array}$ & $\begin{array}{l}15 \\
15 \\
\text { Temp. } 573\end{array}$ & $\begin{array}{l}200 \\
2.00 \\
2.100\end{array}$ & 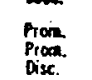 & no \\
\hline $\begin{array}{l}\text { tivaide } \\
\text { stite suive }\end{array}$ & res. & Inds, & cull & 2175 & 3 & & & Sin Miguet & $\cdots$ & & 300 & 10 & & & none & & & Term. ars & & Dise. & No \\
\hline 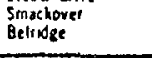 & cht & $\begin{array}{l}\text { Ouschils } \\
\text { Retn }\end{array}$ & Phill in & 5/68 & 2.385 & $\begin{array}{l}130 \\
250\end{array}$ & 3 & $\begin{array}{l}20 \text { n } \\
\text { Sulver }\end{array}$ & 35 & $\begin{array}{l}2.000 \\
3.000\end{array}$ & $\begin{array}{l}1.000 \\
1.000\end{array}$ & $\begin{array}{r}20 \\
14 \\
\end{array}$ & ${ }_{1.34}^{75}$ & $8_{90}^{110}$ & frie. & 71 & $\$$ & if & $\begin{array}{l}5.200 \\
5.900 \\
\end{array}$ & $\sin x$. & \\
\hline
\end{tabular}




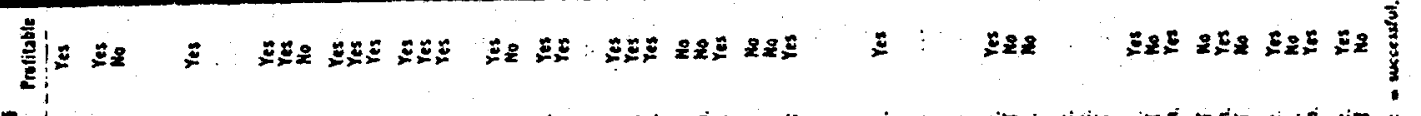

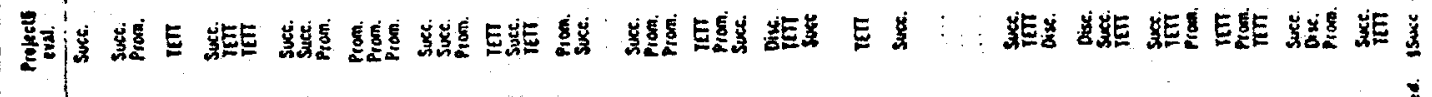

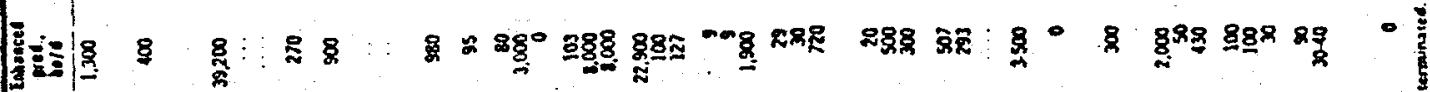

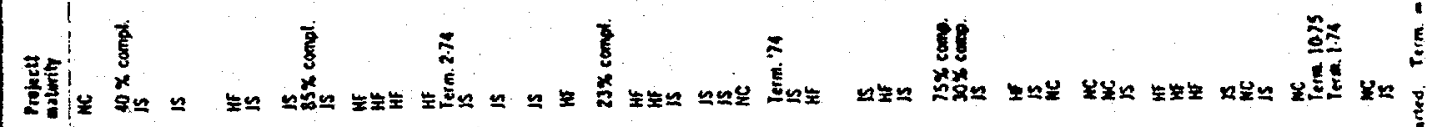

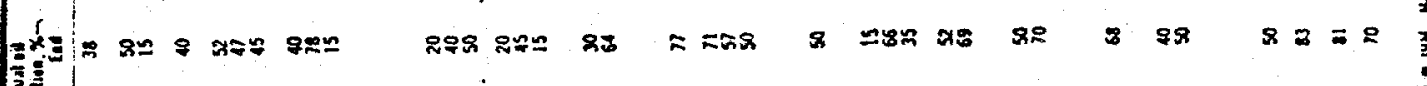

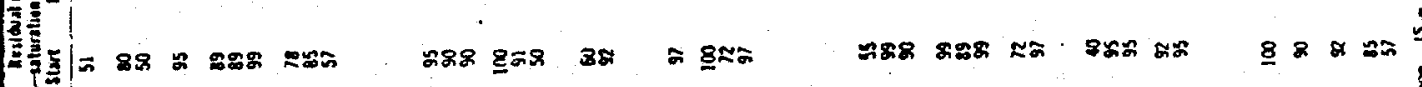

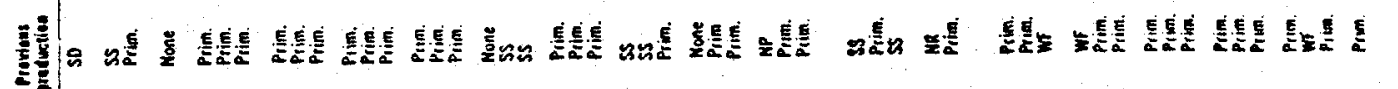

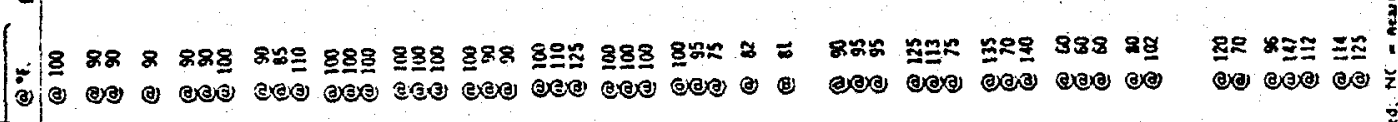

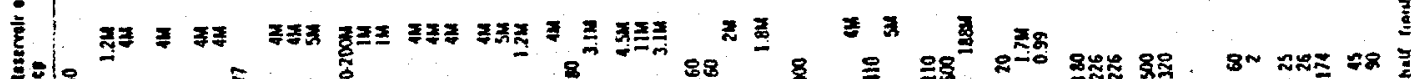

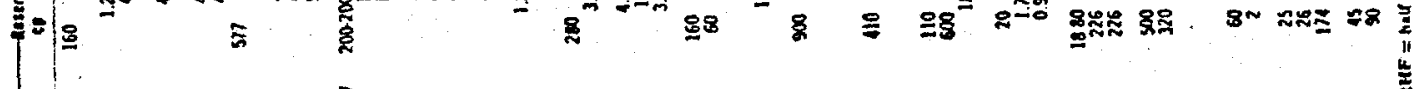

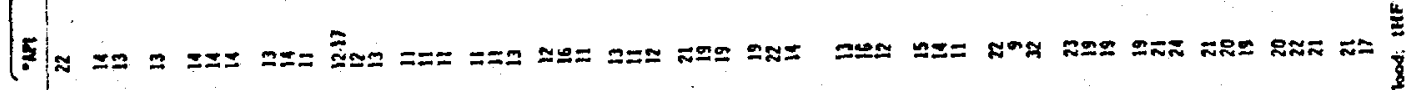
荕

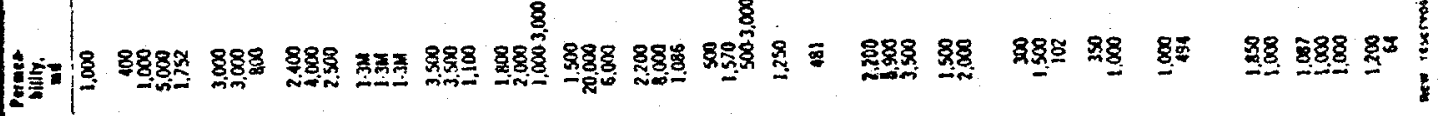

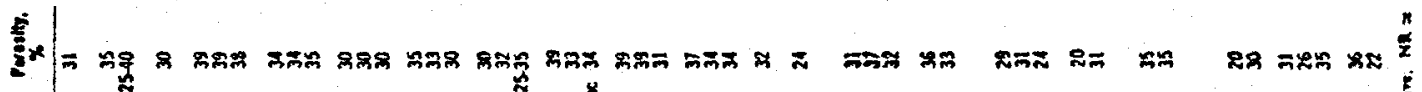

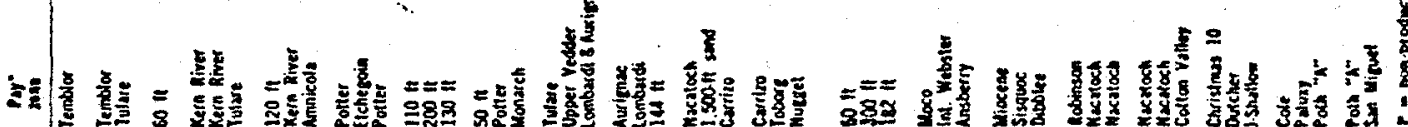

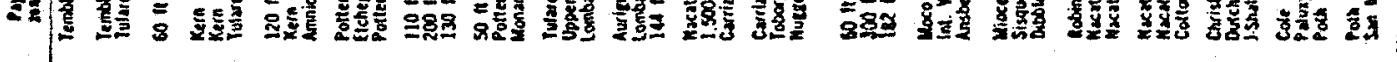

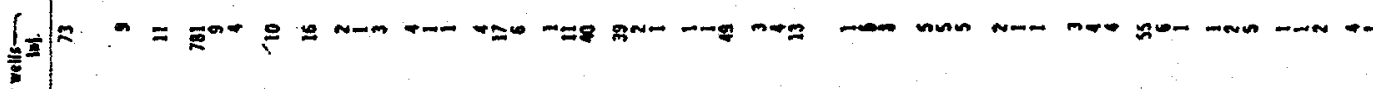

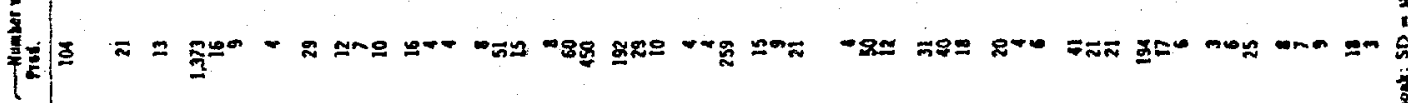

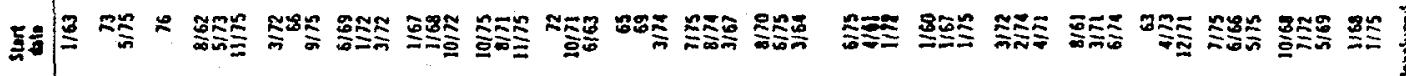

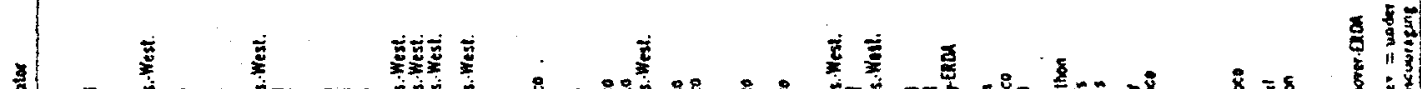

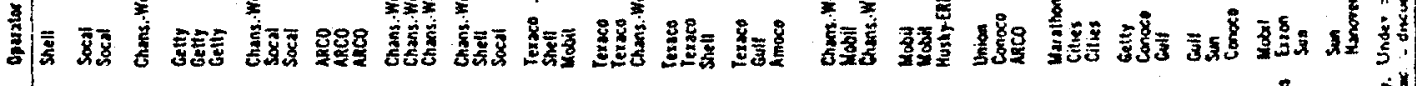

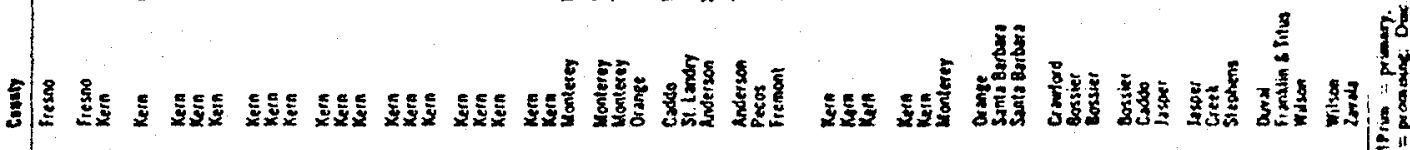

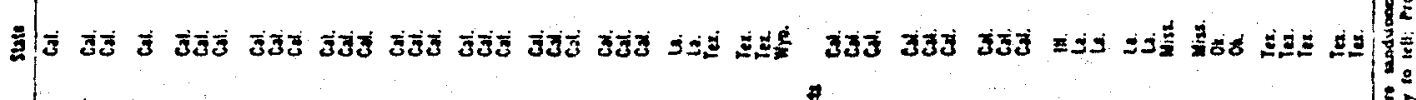

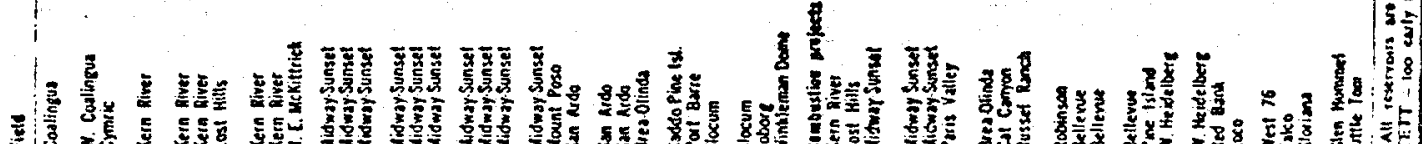

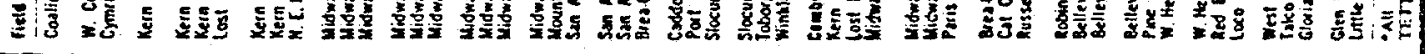


Table 2.3.2-4 Major heavy oil fields around the world 24

(all crudes $<20$ API $I^{\circ}$ are included).

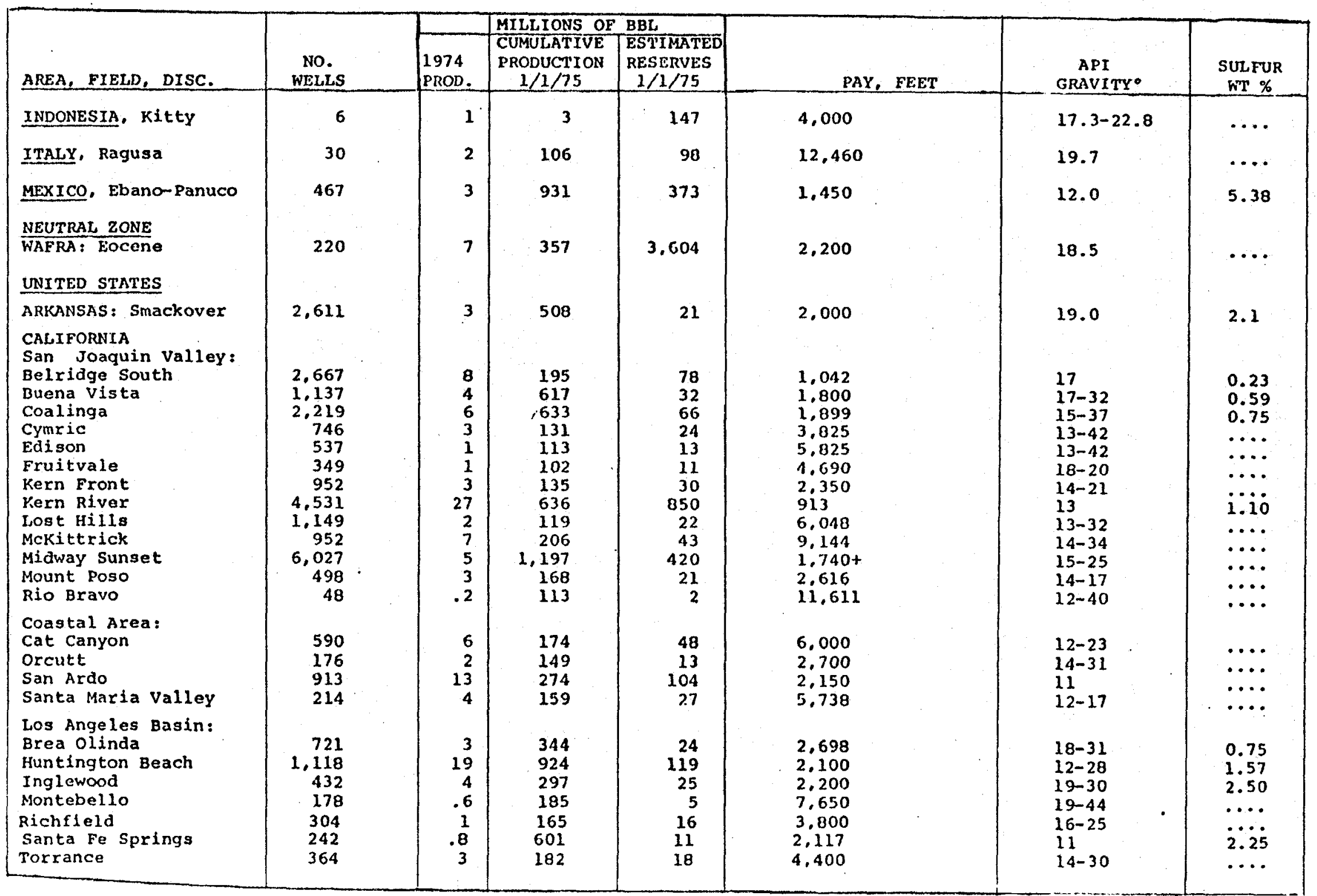


Table 2.3.2-4 (Continued)

\begin{tabular}{|c|c|c|c|c|c|c|c|}
\hline \multirow[b]{2}{*}{ AREA, FIELD, DISC. } & \multirow[b]{2}{*}{$\begin{array}{l}\text { No. } \\
\text { WELLS }\end{array}$} & \multirow[b]{2}{*}{$\begin{array}{l}1974 \\
\text { PROD. }\end{array}$} & \multicolumn{2}{|c|}{ MILLIONS OF BBL } & \multirow[b]{2}{*}{ PAY, FEET } & \multirow[b]{2}{*}{$\begin{array}{c}\text { API } \\
\text { GRAVITY }\end{array}$} & \multirow[b]{2}{*}{$\begin{array}{l}\text { SULFUR } \\
\text { WT } \%\end{array}$} \\
\hline & & & $\begin{array}{c}\text { CUMUIATIVE } \\
\text { PRODUCT ION } \\
1 / 1 / 75\end{array}$ & $\begin{array}{l}\text { ESTIMATED } \\
\text { RESERVES } \\
1 / 1 / 75\end{array}$ & & & \\
\hline UNITED STATES $\left(\operatorname{con}^{\prime} t\right)$ & & & & & & & \\
\hline $\begin{array}{l}\text { LOUISIANA ONSHORE: } \\
\text { Lake Barre }\end{array}$ & 119 & 5 & 172 & 49 & $3,400+$ & $18-45$ & 0.49 \\
\hline $\begin{array}{l}\text { LOUISTANA OFFSHORE: } \\
\text { West Delta Blk. } 30\end{array}$ & 216 & 22 & 312 & 137 & $2,152+$ & $18-34$ & 0.33 \\
\hline $\begin{array}{l}\text { MISSISSIPPI, Baxterville } \\
\text { TEXAS }\end{array}$ & 198 & 7 & 167 & 68 & $3.158+$ & $12-19$ & 2.71 \\
\hline $\begin{array}{l}\text { District 3: } \\
\text { Hull-Merchant } \\
\text { lumble All } \\
\text { Magnet Withers All } \\
\text { Raccoon Bend } \\
\text { West Columbia }\end{array}$ & $\begin{array}{l}385 \\
413 \\
286 \\
135 \\
193\end{array}$ & $\begin{array}{l}2 \\
1 \\
3 \\
2 \\
1\end{array}$ & $\begin{array}{r}194 \\
162 \\
81 \\
92 \\
158\end{array}$ & $\begin{array}{l}11 \\
28 \\
44 \\
33 \\
12\end{array}$ & $\begin{array}{l}400 \\
700+ \\
838+ \\
900+ \\
600+\end{array}$ & $\begin{array}{l}18-50 \\
18-44 \\
15-59 \\
19-39 \\
18-60\end{array}$ & $\begin{array}{l}0.35 \\
\ldots \ldots \\
\ldots \ldots \\
\ldots \ldots\end{array}$ \\
\hline $\begin{array}{l}\text { District } 4: \\
\text { Quitman Ali }\end{array}$ & 246 & 3 & 80 & 29 & $3,980+$ & $16-67$ & ... \\
\hline $\begin{array}{l}\text { District } 8: \\
\text { Dollarhide }\end{array}$ & 147 & 6 & 150 & 60 & $6,500+$ & $18-45$ & $\cdots$ \\
\hline $\begin{array}{l}\text { WYOMING } \\
\text { Hamilton Dome }\end{array}$ & 246 & 4 & 218 & 36 & 2,000 & $15-25$ & 3.07 \\
\hline $\begin{array}{l}\text { VENEZUELA } \\
\text { Anzoategul : Merey } \\
\text { Monagas: }\end{array}$ & 252 & 9 & 178 & 73 & 5.700 & 11.4 & $\cdots$ \\
\hline $\begin{array}{l}\text { Morichol } \\
\text { Quiriquire } \\
\text { zulia: }\end{array}$ & $\begin{array}{l}106 \\
372\end{array}$ & 10 & $\begin{array}{l}115 \\
722\end{array}$ & $\begin{array}{r}90 \\
768\end{array}$ & $\begin{array}{l}3,312 \\
7,200\end{array}$ & $\begin{array}{l}10.7 \\
16.4\end{array}$ & $\cdots$ \\
\hline $\begin{array}{l}\text { Boscan } \\
\text { Mene Grande } \\
\text { Tila Juana }\end{array}$ & $\begin{array}{r}279 \\
310 \\
1,827\end{array}$ & $\begin{array}{r}26 \\
4 \\
116\end{array}$ & $\begin{array}{r}494 \\
580 \\
2,909\end{array}$ & $\begin{array}{r}542 \\
588 \\
1,586\end{array}$ & $\begin{array}{l}7.500 \\
4.132 \\
3.000\end{array}$ & $\begin{array}{l}10.3 \\
18.8 \\
18.8\end{array}$ & $\begin{array}{l}5.53 \\
2.65 \\
1.49\end{array}$ \\
\hline
\end{tabular}


2.3.3 Ultimate Recovery of Heavy Oils (Proved Reserves)

In the above discussion, the term resource has been used to designate the amount of oil-in-place. Typically, only about on-third of this oil is recoverable by conventional technology. This means that one-third of the oil in the ground can be brought to the surface. However, in the production of heavy oils, heat must be applied to the reservoir to render the oil fluid. This is generally done by the injection of steam, which also aids in pushing the oil to the production well. This steam, in turn, is commonly generated by burning a portion of the crude that has already been produced. As much as $40 \%$ of the produced crude oil may be consumed to generate the required steam. Thus, only $20 \%$ of the original oil-in-place would be available for sale. This saleable heavy crude oil will require upgrading to conventional crude quality, which results in adaitional losses of resource.

In the case of recovery of heavy oils by above-ground mining of tar sands, much energy is consumed in the removal of overburden, mining of the tar sands, and land reclamation. This energy may have to be supplied by the crude which is produced. Thus, only about $50 \%$ of the original heavy oil would be recovered for sale or upgrading.

Accordingly, the province of Alberta has recently initiated economic studies to assess the ultimate recoverable resources and the ultimate yield of upgraded crude for each of the major tar-sand deposits in Alberta. 12 similar studies were recently conducted for united States tar sands using somewhat different criteria for reserve estimation. ${ }^{13}$

In the Alberta study, individual zones of cold Lake and Wabasca were treated separately. The reader is referred 
to the above-cited work for specific details. A summary of the reported conclusions is presented in Table 2.3.3-1. A summary of the areas of economic recoverability of Alberta deposits is provided in Fig. 2.3.3-1. As can be seen from the table, only a small fraction of the original oil in place is estimated to be actually recoverable as upgraded crude oil.

It is significant to note that the fractional recovery from mined sands is about twice that for in situ production of Athabasca sands. Thus, mining is the preferred route where possible. In situ production from other reservoirs in Athabasca provides very low yields of recoverable oils $(2-6 q)$.

For economical recovery of the bitumen from a given deposit, certain criteria must be met. The authors of the cited paper 12 have made assumptions for mineability based on the weight percent of raw bitumen present, the overburden thickness and the energy required for mining the bitumen. Accordingly, they obtain a "mineability factor" which they assume must be $>5$ to have an economically viable recovery. Figure 2.3.3-1 shows the zones which meet this criterion in Athabasca.

Similarly, when the bitumen is produced via steam injection, a certain fraction of the crude must be burned to generate steam. For such steaming to be economical, a criterion of "thermal ratio" (crude produced vs. crude burned) was developed.12 A value of four was believed to be required for economic production. In Fig. 2.3.3-1, the zones of economic producibility by steam for Alberta's tar sands are presented.

One basic flaw in these calculations is the assumption that all forms of energy are equivalent. 
Table 2.3.3-1 Ultimate recoverability of tar-sand bitumen in Alberta; * from Ref. 12.

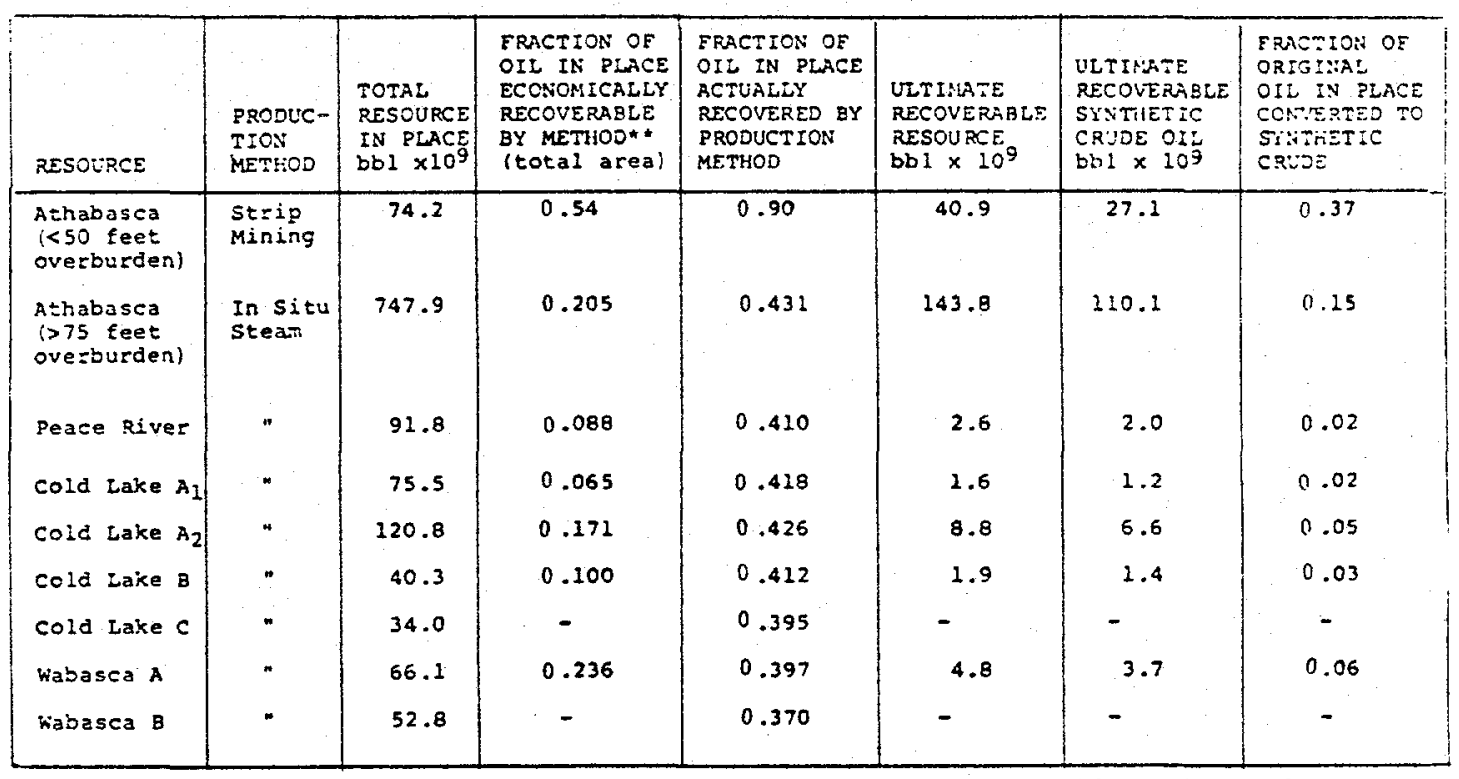

Tiot al- data have been entered. These figures represent the most reasonable estitiates for favorabie conomic recovery of the resources. For all data and bases the reader is referred to the original paper.

* This figure represents that fraction of the deposit which lends 1 tseif to production by the method being considered. Economic criteria are defined in Ref.12. 


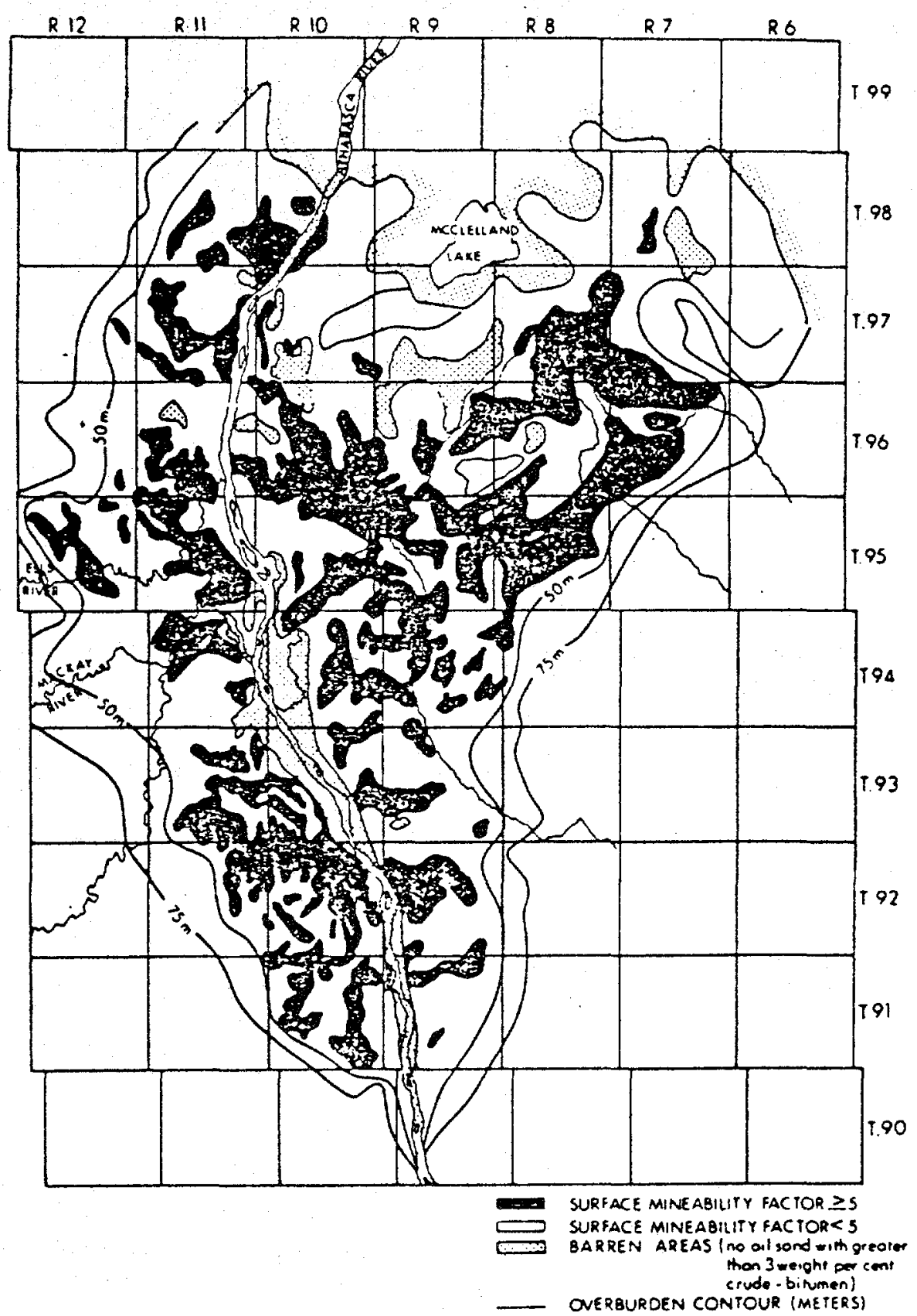

Fig. 2.3.3-1 Surface-mineable oil sand deposits in the Athatasca area. 
Replacement of the energy source for the production by a less valuable fuel (e.g., coal) could provide the same BTUs at lower cost. This, in turn, would allow higher ultimate yields of upgraded crude. Imperial Oil has considered coal as a heat source in Alberta.

Similar studies in the United States, conducted under Contract 9014-018-021-22004 for DOE in 1978, provided a detailed analysis of the ultimate producibility of U.S. tar sands. The authors of this report concluded that only $\sim 0.1-0.2$ billion barrels of U.S. tar sands could be recovered by mining and $\sim 2$ billion barrels of oil could be recovered by in situ techniques.

An assessment of the potential recoverable reserves of heavy oils ( $<20$ API with some mobility in place) was conducted in 1966; at that time, estimates of 2.5 to 5.5 billion barrels of recoverable reserves were made. However, these data did not include information on Alaskan oil. Many new heavy oil reservoirs have been identified since that time and it would be advisable to update these earlier figures.

\subsection{Recommendations}

This brief review of the resources and reserves of the United states clearly shows that much valuable information is lacking on potential contributions of heavy oils and tar sands to the future energy needs of the united states.

Resources and reserves need to be much more clearly defined, both in terms of resource quantity and the physical and chemical properties of the oil-in-place. We recommend that a systematic assessment of the U.S. tar sands and heavy oil resources be undertaken. This assessment should include enough detailed information about the criticalities in either mining or in situ stimulation to allow reasonable 
estimates of the proved and potential reserves from all major U.S. reservoirs. An approach similar to that taken in Albertal2 and in past surveys in the U.S.13 is strongly recommended. This information should be made available in a manner similar to the Bureau of Mines crude assay data bank (either in the form of computer cards or tapes) so that commercial ventures can be encouraged. 
CHAPTER 3

PROCESS RESEARCH RELATING TO

OIL RECOVERY FROM TAR SANDS AND

HEAVY OIL SOURCES

The following discussion deals with oil recovery from tar sands and heavy oil sources.

First-generation technology for oil recovery from tar sands through surface mining and aboveground processing is being practiced commercially in Canada (cf. Sec. 1.2). Considerable work is in progress to demonstrate modified and alternative extraction concepts in place of the hot water process practiced in Canada. These operations are being conducted in large-scale demonstration plants located in the field. The concepts involve solvent extraction, 1 incorporation of a high shear mixing step in the hot water process, 2 and pyrolysis. 3

Laboratory testing of advanced concepts using fluid-bed pyrolysis $^{4}$ are under way.

1 "In California Diatomite May Yield Petroleum," Geotimes, March 1981; G. Karnofsky, "Solvent Extraction of Bitumen from Tar Sands and Diatomaceous Earth," Dravo Engineers \& Constructors

2 J. E. Sepulveda and J. D. Miller, "Separation of Bitumen from Utah Tar Sands by a Hot Water Digestion-Flotation Technique," Technical Papers; J. R. Smith and J. D. Miller, Society of Mining Engineers of AIME, Preprint No. 80-100, AI ME AnnuaI Meeting, Las Vegas, Nevada, February 24-28, 1980; M. Misra and J.D. Miller, "The Effect of Feed Source in the Hot Water Processing of Utah Tar Sand," Mining Engineering, March 1980; J. D. Miller and M. Misra, "Concentration of Utah Tar Sands by an Ambient Temperature Flotation Process," University of Utah, Salt Lake City, Utah, 1981.

3 R. W. Rammler, Canadian Journal of Chemical Engineering 48, 552 (1970).

4 V. N. Venkatesam, F. V. Hanson, and A. G. ObIad, "The Thermal Recovery of a Synthetic Crude from the Bituminous Sands of the Sunnyside (Utah) Deposit," First International Conference on the Future of Heavy Crude and Tar Sands, Edmonton, Alberta, Canada, June 4-12, 1979. 
The major portion of the tar sands resource will have to be processed by applying in situ techniques. In situ processing has not been commercialized on tar sands and is currently limited to field tests. Two of the ongoing projects are described in the site visit reports on the Shell Canada test site at Peace River ( $A B-7$ ) and the Saner Ranch work of Mobil and Continental Oil (AB-5). Combustion and steam drives are being investigated. Novel ideas dealing with radio frequency heating and combinations of mining and in situ methods have also been proposed but have not been tested on substantial scales.

\subsection{Surface Mining and Aboveground Processing of Tar Sands}

The large and long-duration setting ponds associated with the water extraction process present a challenging and serious problem and may be needed for some U.S. tar sands. Development work on ways to reduce the oil content of the aqueous residues from the process should be supported at both the laboratory and demonstration scales. It is also desirable to develop economical methods for diminishing the settled volumes of inorganic fines in the ponds, thereby reducing the ultimate sizes needed for the ponds. Purification of large volumes of clarified water will generally be a site-specific investigation. Successful fundamental studies should provide leads relating to the effectiveness of the use of resins, microbial action, floatation, oxidation, colloidal techniques, flocculation, etc.

Solvent extraction of tar sands eliminates serious problems encountered in connection with use of the settling ponds that are needed in the hot-water Clark process. On the other hand, the use of solvents entails the disadvantages associated with handling large amounts of expensive, flammable solvents and the associated augmented capital and operating costs. An item requiring special attention is the reduction of hydrocarbons in 
the discharge sand streams to acceptable levels in view of existing air standards. A number of industry-sponsored projects is currently underway utilizing solvent extractions. Because of these proprietary investigations, only fundamental research is recommended in this area. However, the support of field projects may be appropriate when the federal government is involved as a partner.

Thermal processing techniques, such as those proposed by Lurgi and Taciuk, 5 as well as the use of fluid-bed technologies, will involve the common problems of solids removal from liquids and gases and combustion of coke on the pyrolyzed sand. Improved methods and apparatus for implementing these processes should be supported at both the laboratory and demonstration scales.

\subsection{In Situ Processing of Tar Sands and Heavy Oil Sources}

In situ processing has two characteristics which are fundamentally different from mining followed by aboveground processing. These bear importantly on the choice of appropriate research topics and on prospects for success. In situ recovery involves wellbore technology. This statement implies that only very limited control can be exercised over flow processes in the reservoir. Furthermore, it is not possible to obtain exact information on reservoir properties and flow conditions. Secondly, it is practiced in hundreds of reservoirs. There are, perhaps, thousands of candidate reservoirs. Each site or potential site represents a unique situation characterized by oil properties, host-rock, reservoir fluid, geology, resource size, etc. This diversity means that each site or potential site has many characteristics that require site-specific approaches. The search for a general solution to improved in situ recovery may not be fruitful.

5 Taciuk Oil Sands Processor, Nonconfidential Disclosure and Consultive Participation Information Brochure, Alberta Oil Sands Technology and Research Authority and UMATAC Industrial Processes, Ltd., April 1981. 


\subsubsection{Intensive Oil and Rock Properties}

Those oil and rock properties which depend on the composition but not the spatial arrangement of oil and host rock are most susceptible to fruitful laboratory studies. Generally, this means defining the chemistry of the reservoir of interest. Topics for study in this category include, for instance, (a) rock mineralogy, (b) chemical compositions of oils, (c) interactions of clay with caustic, (d) absorption and adsorption data on surfactants, (e) reservoir brine compositions, (f) interfacial tension modification by surfactants, (g) sacrificial surfactants, (h) oxidation processes occurring underground, (i) reservoir pressures as functions of variables, ( $j$ ) reservoir temperatures as functions of other parameters.

In many cases, examination of intensive oil, rock, and reservoir properties will narrow the range of possible EOR techniques and suggest likely candidates. The thermodynamics of oil-rock interactions has been formulated with elegance and generality. ${ }^{6}$ Unfortunately, the data tend to be highly specific to the intensive properties of the candidate reservoir under study. Possibly, if the required data were available in many cases, they could be used to estimate upper limits on recovery possibilities. At present, such estimates can probably be produced to useful accuracy by rules-of-thumb or by assumption.

It has been suggested that amassing data banks covering many reservoirs will be useful. This hypothesis seems questionable because, since reservoir data are extremely site-specific, the data bank may have limited general utility. At the present time, it is still necessary that holders of individual candidate reservoirs develop the specific data needed for their own particular resource.

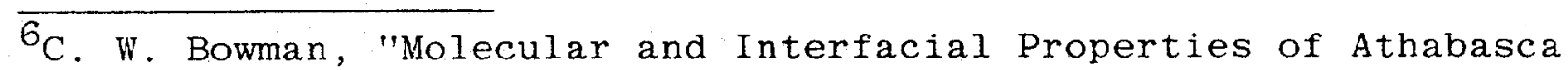
Tar Sands," 7 th World Petroleum Congress, Vol. 3, pp. 583-640, Elsevier, 1967 . 


\subsubsection{Reservoir Descriptions and Modeling}

Real reservoirs regularly contain faults, inhomogeneities, and other such unpredictable structures that it is not to be expected that laboratory results will be matched in the field. Wathematical reservoir modeling has proved to be useful in relating physical descriptions of a reservoir with data on oil, rock, and other intensive properties to suggest in situ process control strategies and to predict performance results for given control strategies.

As the computational art has advanced, models have become larger and more sophisticated. Not surprisingly, there is a continuing demand for larger and more exact models (which, of course, require better input data) and for more exact resource characterization (which requires better models to utilize the data). There is no limit, in a practical sense, to the size and sophistication of models nor to the detail with which data may be developed. It is, however, axiomatic that perfect reservoir descriptions can never be had.

Each specific proposal must necessarily be judged on its merits. Criteria such as the following may be useful:

(a) Will more data (improved resource characterization, indirectly measured in situ diagnostics) cause a given model to produce different results?

(b) Will an improved model formulation (e.g., more exact flow equations) utilize data which can be obtained at reasonable cost?

(c) Given new information (model predictions) from (a) and (b), can this information be implemented in new and practical field operating procedures?

(d) Will the new procedures improve project economics?

If affirmative answers are not expected at the outset, 
healthy skepticism about the proposed new data and/or modeling seems in order.

\subsubsection{Tar-Sands Processing}

Because the viscosity of oil decreases exponentially as the temperature is raised, heat injection or in situ heat generation in a reservoir may be desirable procedures if the reservoir conditions are favorable. Two methods for heating the reservoir are steam injection and in situ combustion of hydrocarbons (coke).

\subsubsection{Thermal Recovery with Steam}

A useful steam soaking technique is huff-and-puff steaming. In this procedure, steam is injected for a period of time into the well and the flow of steam is then terminated after soaking. The well is subsequently put on production. For suitable formations, augmented production will result for an acceptably long period of time.

An alternative idea involves steam drive. In this process, the steam flows into the oil reservoir through injection wells and the reservoir oil is produced through adjacent production wells. Formation permeability and oil saturation must be adequate for implementation of this procedure.

The following application areas should benefit from a field-test support program: (a) establishment and maintenance of flows; (b) generation of lower cost steam, e.g., by fluidbed combustion using lower cost fuels than are produced; (c) improvement of down-hole steam generation; (d). measurements of down-hole steam quality; (e) determinations of benefits derived from the use of clay stabilizers by multiple-well testing in a sensitive fresh-water formation; (f) improved processes for recycling water to the steam-generation plant or preparing the water for disposal; (g) steam distributions to produce reductions of channeling and of steam override; $(h)$ the use of reduced well spacing; (i) use of drainholes; (j) high-pressure injection of steam into low permeability formations. 


\subsubsection{Thermal Recovery with Combustion}

In situ combustion methods are used in a number of variations. These encompass dry combustion using only air injection and quenched in situ combustion which utilizes simultaneous or alternate injection of air and water into a reservoir that supports burning. Quenched combustion produces flows of flue gases through the formations. High-pressure, down-hole steam generation also induces flows of the flue gases through the formations.

The sequential use of reverse combustion during a preparatory stage, followed by a forward combustion drive, has been reported.

Support of field projects is desirable in each of the following areas. (a) The development of high-temperature packers and insulation systems merits support. (b) Steam generation in the oil formations by means of in situ combustion and water injection, with supplementary injection of fuel for in situ combustion, is an untested technique that may improve the in situ generation of steam. (c) Cleanup and disposition of low Btu gases and their use for cogeneration of air compression are possibilities. (d) The determination of benefits derived from injection of oxygen-enriched air or pure oxygen should be studied.

\subsubsection{Novel Techniques}

The following discussion covers some novel ideas which may be applicable to in situ processing. Support for these concepts at the pilot plant and field stages is worthy of consideration.

\section{A. Radio-Frequency Heating}

As proposed by workers at the Illinois Institute of Technology, a pattern of bore holes is drilled at a suitable site. This pattern of conductors is designed in such a manner that radiofrequency energy may be applied. The formation is first 
heated to $100^{\circ} \mathrm{C}$ and, subsequently, the bore holes are converted into injection and production wells. A hot caustic flood has been proposed for later injection.

\section{B. Mine-Assisted Steam Injection}

Several concepts have been proposed for mine-assisted steam injection. A modified in situ process involves rubblizing the formation so that in situ techniques can be used in highly permeable sections. Another idea requires drilling of tunnels upward. Heat is injected to cause the oil to drain into the tunnels. Alternatively, caverns could be mined and horizontal radial wells drilled into the formations.

These concepts relate especially to improved steam-contacting within the reservoir bed. There are uncertainties in every aspect of the processes involved: (i) the reservoir may be inadequately characterized and space-dependent estimates will not be available for porosity, oil in place, permeability, surface properties, (ii) if the reservoir bed were adequately characterized, the flow of the reacting fluids through the porous beds could be described quantitatively only if constitutive equations were available under reservoir conditions; (iii) improved in situ diagnostic procedures are needed to follow the progress of steam floods through the reservoir beds.

The idea that directional drilling and horizontal injection at selected reservoir depths will improve oil recovery has practical appeal and the resulting measurements may be expected to lead to improved reservoir-performance models.

\section{C. $\mathrm{CO}_{2}$ Huff and Puff}

Alternate injection and release of $\mathrm{CO}_{2}$ in a formation with suitable integrity, both with and without steam preheating, offers possible advantages that are worth pursuing. 


\subsubsection{Process Research Relating to Heavy Oil Sources}

As with mining and aboveground processing of tar sands, EOR for heavy oil sources is commercial technology. In fact, U.S. oil production from these sources is about twice the rate of Canadian syncrude production.

The in situ techniques used with the tar sands are applicable to heavy oil sources. These include thermal processes using steam, combustion, a combination of steam and combustion, $\mathrm{CO}_{2}$ injection, etc. In addition, surfactant chemicals are sometimes employed.

\subsubsection{Fundamental Supporting Research}

The following research items cover both laboratory and field tests and apply to either or both surface or in situ processes.

\section{A. Basic Clay Research}

An area of research applicable to both surface and in situ tar sands processing is related to the effects of fresh water solutions on some clays. Basic research on the properties of clays, using the best available analytical techniques and tools, will be useful for two reasons: (a) better understanding of clay properties should lead to reductions of oil loss in silts and clays and consequent reductions of the sizes needed for the holding ponds encountered in practice when the hot-water bitumenrecovery process is employed; (b) new approaches may lead to the stabilization of fresh-water sensitive formations containing swelling clays.

Fundamental work should be pursued on purifying the clarified process waters to make them environmentally acceptable. 


\section{B. Sand Control}

In practice, the present need to control the flow of sand may represent a serious impediment to achieving lasting oilproduction improvements. Alternatives to sand control in unconsolidated formations should be investigated. The sand-bitumen mixture could be produced and separated at the surface. The method of lifting could involve a pump capable of handling a slurry. Development work on such a pump would be appropriate.

\subsubsection{Transportation of Bitumen-Water-Sand Slurries}

Bitumen-water-sand slurries ${ }^{7}$ have been shown to have greatly reduced viscosities at moderate temperatures. A large scale field test to determine the feasibility of using slurries rather than diluents would be of interest.

\subsubsection{Down-Hole Steam Generation}

Each of the following R\&D programs may contribute to better understanding and improved oil recovery in the long-term utilization of down-hole steam generators: (a) combustion research (including equipment changes, use of preheaters, recirculation, etc.) to allow direct utilization of oil-field crude in down-hole steam generation; (b) long-term environmental impact assessments (involving both gaseous effluents and residue stability) with down-hole steam generation; (c) quantitative studies on the efficacy of mixtures of steam and combustion products in enhancing oil recovery.

7 R. Simon and W. G. Poynter, Patent No. 3,519,006 on "Pipelining Oil/Water Mixtures"; Patent No. 3,425,429 to Chevron, "Method of Moving Viscous Crude Oil through Pipeline"; R. Simon and W. G. Poynter, "Downhole Emulsification for Improving Viscous Crude Production," Journal of Petroleum Technology 20, 1349 (1968). 


\subsubsection{High-Temperature Packers and Insulation Systems}

Material problems and studies bear on the design of packers to confine fluids in the well annulus. The high-temperature environments under which the packers and insulations systems must function for prolonged periods of time pose special problems. Of particular importance is maintenance of bottom-hole integrity with quantitative characterization of heat and other losses.

\subsubsection{Reservoir Properties Research}

This program will presumably emphasize the fluid-dynamic aspects of reservoir modeling, with particular attention to physical properties that determine absolute and relative permeabilities and fluid movements.

\subsubsection{Compatibility Studies}

Transportation of the bitumen produced from in situ processing usually requires addition of a diluent. Compatibility studies for projected mixtures would be useful. 
CHAPTER 4

ENVIRONMENTAL ASPECTS*

Oil from tar sands and heavy oil crudes cannot readily be extracted because of their high viscosities at reservoir temperatures. They are found in a variety of deposits and display a wide spectrum of site-specific properties. The mobilities of these oils are increased by using a variety of heating techniques or by extraction with chemical additives. Both in situ and aboveground treatments are used. Domestic reserves of heavy oil sources need to be better characterized and are currently estimated at 110 to 125 billion barrels of which 7.5-20.5 billion barrels appear to be recoverable at competitive costs. Current domestic production from EOR is about 300,000 barrels per day. Expanded production has been restricted by economic and environmental constraints. Current domestic production is accomplished by using in situ EOR. Domestic aboveground processes are still at the model study stage.

Most of the environmental problems can be solved through application of existing control technologies. However, currently available control technologies may be costly. There are areas where research would be expected not only to lessen environmental impacts but also to improve process economics. We focus here on key environmental issues for which further research may be expected to have a significant impact on production. Our discussion is not meant to represent a review of all of the many environmental problems which could be addressed. Important issues relate to air, water and land disturbances.

\footnotetext{
* This chapter should be read in conjunction with a recently completed NRC study entitled "Synfuels Facilities Safety," National Research Council, Assembly of Engineering, Committee on Synfuels Facilities Safety, Washington, D.C., April 1982.
} 


\subsection{Air Quality}

Air-quality constraints are potentially limiting in the use of thermal methods for enhanced oil recovery when the combustion phase takes place above ground. Steam-injection technology is widely used in Kern County and air-quality considerations in this area illustrate the serious nature of the problem. If crude oil is burned as a heat source, problems may arise from the production of $\mathrm{SO}_{x}$, NO $\mathrm{N}_{\mathrm{x}}$, particulate matter, and hydrocarbons. Roughly one barrel of oil is burned for everv two to three net barrels of oil produced.

The sulfur contents are typically 1-1.5\%. During combustion, $99 \%$ of this sulfur is converted to $\mathrm{SO}_{2}$ along with $1 \%$ of $\mathrm{SO}_{3}$. Thus, 7.5 pounds of $\mathrm{SO}_{2}$ are produced for every barrel of oil burned. The current Kern County emissions limits are 250 tons of $\mathrm{SO}_{2}$ daily.

The $\mathrm{NO}_{\mathrm{x}}$ emissions are produced, in part, by combustion using air (thermal $\mathrm{NO}_{\mathrm{x}}$ ) and, in part, from nitrogen in the fuel. The steam generators used in Kern County have typical $\mathrm{NO}_{x}$ emissions of 3.5 pounds per barrel of crude burned. The total $\mathrm{NO}_{\mathrm{x}}$ emissions from thermally enhanced crude oil production in Kern County are about 120 tons per day. Uncontrolled emissions of particulate matter are 0.66 pounds per barrel burned, with current daily emissions estimated to be 23 tons per day. During steam drive, hydrocarbons are emitted along with excess steam from the well casing. These emissions are estimated to be 337 tons per day for all of the wells in Kern County.

There currently exist partial technical solutions to these emission problems. The $\mathrm{SO}_{\mathrm{x}}$ emissions are most commonly controlled by flue-gas desulfurization using exposure to a single pass through sodium hydroxide, lime or limestone slurry, or double alkali solutions. With all three of these methods, $95 \%$ reductions in $\mathrm{SO}_{\mathrm{x}}$ are achieved. Sodium hydroxide and lime are currently in 
service on oil-field steam generators. These methods produce additional environmental problems in the disposal of the scrubber waste stream, either through reinjection into the well, in a holding pond, or another storage area. The wastes are classified under current regulations of the Resource Conservation and Reclamation Act. Disposal sites in Kern County are rapidy running out of capacity. The scrubbers are not cheap and they have been estimated to contribute as much as \$6-9 per barrel of oil produced to the final product cost.

The NO ${ }_{x}$ emissions are partially controlled through combustion modification techniques. With some commercially available burners, $\mathrm{NO}_{\mathrm{X}}$ emissions are lowered by $50 \%$. These are the most cost effective available procedures for reducing $\mathrm{NO}_{\mathrm{x}}$ emissions. A flue gas clean-up technique has been developed in which ammonia is added to reduce $N_{X}$ in the gas stream at $1750^{\circ} \mathrm{F}$. A patented, commercially available system is Thermal DeNO ${ }_{x}$, which is licensed by Exxon. This $N_{x}$ removal system has a very narrow temperature window for effective operation, as well as other critical process variables.

Particulate emissions are currently partially controlled by the $\mathrm{SO}_{\mathrm{x}}$ clean-up procedures. Conventional $\mathrm{SO}_{\mathrm{x}}$ scrubbers remove roughly 50\% of particulate matter. Other scrubbers have been designed to reduce particulate emissions by up to $90 \%$. Electrostatic precipitators and baghouses may also be used. Hydrocarbon emissions can be controlled by trapping the emitted steam at the wellhead and passing it through separators and condensers. The Getty Oil Company has used these systems in Kern County with excellent results.

Since $\mathrm{SO}_{\mathrm{x}}$ emissions are currently believed to be potentially limiting, they should receive priority attention. There is a need for improved scrubber technology and this improved technology should also be of potential benefit in other synfuels 
processes such as direct coal utilization. Current work on down-hole steam generators should be vigorously pursued since recent Sandia studies have shown that most of the emissions will be trapped by the deposits underground. Down-hole steam generation is a more efficient thermal technique than aboveground steam generation and is applicable for deep deposits.

Another useful research area involves approaches for lowering the sulfur contents of fuels before they are burned. This reduction may be accomplished by using available refining technologies but the economics for this approach are unattractive. Research on inexpensive methods for sulfur removal is a high priority recommendation.

A 1979 study by A. Goodley of the California Air Resources Board suggested that $\mathrm{NO}_{\mathrm{x}}$ emissions could be the constraining element for enhanced oil recovery in Kern County. Hence, improved methods should be developed for scrubbing $\mathrm{NO}_{\mathrm{x}}$ from flue gases, including procedures for trapping the nitrogen in usable form for applications in fertilizers and other commercial products.

Among priority research items, we note the need for airdispersion models over mountainous regions, as well quantitative measurements of organic effluents and their toxicological characterization.

\subsection{Water Quality}

Potential problems in enhanced oil recovery or tar sands development are water availability and maintenance of water quality. These are not near or even medium term problems. At steady-state production, it is estimated that 2 to 4 barrels of water will be used for each barrel of oil produced; for comparison, we note that enhanced oil recovery by steam stimulation in 
the Cold Lake region of Alberta involves the use of 2.5 barrels/ barrel. Because in current processes little use is made of process waters, there are several waste streams to be disposed of. The largest of these ( 1.5 barrels/barrel) and the most difficult to treat is the produced water, which is a mixture of condensed steam and the usually saline waters within the reservoirs that are contaminated by an array of not well characterized, dissolved organic materials.

As for air emissions, it appears that water cleanup should be achievable by using currently available technologies. Two potential problems should be emphasized. A probable disposal route could be reinjection into the formation through a deep well. The hydrology of each deposit would have to be well known in order to avoid contamination of high-quality aquifers. However, such aquifers appear to be uncommon at most recovery sites. Standards are now being set, on a state by state basis, for underground injection codes. The proposed Utah code would exempt some aquifers from regulation but would otherwise require modeling and monitoring. The theoretical basis for this type of modeling is not well understood and there have been difficulties in monitoring highly complex hydrological systems. Further studies in these areas, as well as research on improving the quality of recycle waters, are recommended.

Special problems arise with the use of alkyl sulfonates as micellar additives. Studies coordinated at LETC* have shown adverse biological effects for these materials. Investigations are needed to define the migration and ultimate fates of these materials. Similar studies should be performed on the combustion products from bitumens that will be left after applying in situ combustion technologies.

A major problem encountered in the Canadian tar sands industry involves large, highly alkaline tailings ponds. This problem may be absent in the processing of Utah tar sands

* LETC = Laramie Energy Technology Center. 
according to studies performed at the University of Utah. On the other hand, for other resources, aboveground treatments may be used on oils bound to deposits with high clay contents. For these, research on clay chemistry could serve to ameliorate the settling pond problem when it arises. These investigations should include fundamental studies of the effects of surfactants of all types, including microbial surfactants, in enhancing settling rates in tailings ponds.

A long range, fundamental program on water recycling and cleanup, under the special conditions arising in oil recovery from tar sands, should be started. The problem of removing dissolved organics is a priority concern.

\subsection{Land}

We have not noted land-use problems produced by underground enhanced oil recovery. Since the proposed development of the Utah tar sands will utilize surface mining, there is an issue of land reclamation. This problem can, however, be readily solved with good mining practices. The sand returned to the mine will be cleaner than the material that is originally removed. We have not identified research needs relating to land reclamation. 
CHAPTER 5

FUNDAMENTAL RESEARCH ON OIL RECOVERY FROM HEAVY OIL SOURCES AND TAR SANDS

\subsection{Basic Research Policy}

A growing domestic population and continued political and economic uncertainty associated with imported oil have placed an increasing premium on the utilization of oil from tar sands and heavy oil sources, as well as on all other domestic energy supplies. The nature of the supply problems has moved the government to intervene in the energy scene. This intervention, despite current signs of a movement towards detachment, is probably permanent. Against this background, the evolution of long range, joint government-industry policy and action in relation to energy resources are both necessary and appropriate. It is particularly important that these joint endeavors focus on the level and content of the basic research program associated with the development of EOR, heavy oil and bitumen production, and use in the U.S.A.

Basic research requires stable funding, is long range, and is not usually addressed to the solution of near-term problems, although it may be motivated by and relate to these. The impact of basic research often becomes evident in social and technological applications some 20 to 35 years after a discovery is made. This lead time is reduced to 10 to 15 years in rare instances. Such a long time span for potential payout is not an attractive use of available funds, particularly when many shortterm opportunities for more rapid payout are generally available. For this reason, even the most technologically advanced and research oriented industries have generally chosen to put only a small fraction $(0-8 \%)$ of their R\&D efforts into basic research. Traditionally, the investments of private industry in the energy 
area in research and development have been relatively smaller, with correspondingly very modest investments in basic research. This policy is puzzling in view of the fact that many recent advances in this industry have arisen from basic research. An example of the resources allocated to basic research is provided by the Gas Research Institute, which is a cooperative venture sponsored by the public utilities providing natural gas in the U.S. About $8 \%$ of the R\&D effort has been earmarked for basic research (in 1982 , about $\$ 4$ million). This amount should be contrasted with about $\$ 25$ billion in sales generated annually by the U.S. gas utilities.

To enhance the level of basic research, the government can stimulate private industry, either through incentives or by providing funds for this purpose. Without these, the level of funding for basic research on energy is not likely to be commensurate with apparent needs and potential. It has long been known that heavy oils and bitumens exist in quantity in the U.S.A., but it is only in recent times that serious development efforts have been implemented to recover these fuels. While the performance of basic research does not guarantee technological development, our past experience with basic research is that it is the most cost-effective way of making significant new technological discoveries.

A critical question is the level of government effort that is reasonable. Using estimates that have prevailed historically in the petroleum industry with respect to R\&D expenditures relative to sales, we estimate that the oil industry will spend $\$ 30$ to $\$ 60$ million per year on basic research in the EOR and tar oil industries as these resources are phased into production. Persuasive arguments can be made that a comparable sum should be spent in a government program. Historically, private sector and government expenditures in $\mathrm{R} \& \mathrm{D}$ have been about equal. 
5.2 Examples of Basic Research Relating to Oil Recovery from Heavy Oil Sources and Tar Sands

In this section, we list key areas of basic research. In the following sections, we discuss some of these areas in detail.

A. Resource Characterizations:

1. properties of heavy oils and tar sands;

2. methods for resource characterizations;

3. geochemistry of oil-bearing rocks, including the structures of clays, sands, sandstones, etc.

B. Reservoir Characterizations:

1. electromagnetic methods;

2. diagnostics using sound-propagation;

3. studies of elastic waves in reservoirs;

4. nuclear signatures;

5. seismic data;

6. characterizations using a multiplicity of techniques.

In all cases, the emphasis should be on understanding how the measurements yield information on the structure of the porous media and containment of fluids. An instructive example is provided by dielectric constant measurements, for which combinations of theory, laboratory experiments on simulated porous media, experiments on rocks and sands, and finally field tests are required to establish assessments for the utility of these data as a function of frequency.

C. Flows in Porous Media:

1. the theory of one-component flows in non-isothermal porous media (for various gas-surface interaction models), as verified by laboratory experiments;

2. flows of mixtures with two and more components through porous media;

3. multiphase, multicomponent flows. 
For these important studies, applicable constitutive equations are required, which must be solved with proper allowance for thermal, diffusive and reactive processes, subject to well defined initial and boundary conditions.

D. Physico-Chemical Phenomena:

1. thermodynamic equilibrium data for appropriate multicomponent systems;

2. thermochemical and transport coefficients;

3. interfacial phenomena;

4. wetting of porous media;

5. surfactant designs and mechanisms by which they act, including studies of emulsification;

6. behavior of polymers that have been added to effect drag reductions, oil/water compatibility, modifications of surface forces, etc.;

7. interactions of chemical additives with oil-bearing sands and rock surfaces, including especially studies of the influence of $\mathrm{pH}$.

E. Reservoir Engineering:

1. Simulation of forced flow patterns in rock matrices;

2. improvements in modeling multiphase flows in porous media during resource recovery.

F. Thermal Recovery:

1. in situ combustion phenomenology, with emphasis on flame-front propagation, wave stability, reproducibility of measurements, and model validation;

2. steam flow patterns and steam recovery;

3. reservoir integrity during resource recovery, thermal front mapping, and comparisons with model predictions.

G. Materials Problems:

1. down-hole erosion and corrosion assessments;

2. pumps and valves for operation in high-temperature, high-salinity environments. 


\subsection{Resource Characterization}

Unusual problems result from resource inhomogeneities. There is no one characteristic or canonical heavy oil or tar sand. There are many sources and products, varying broadly in chemical composition and physical properties and occurring under an extraordinary diversity of conditions and terrains. This variability has profound effects on the technologies that may be used in the recovery of heavy oils from a given location. A successful approach in one deposit does not guarantee similar success in another, even in a nearby field.

The diversity of oil-sand materials suggests that a prime task is establishment of major categories of heavy oils and of sand formations. If this program succeeds, then a central sample bank could be used to make comparisons of results obtained at different locations. Resource classification programs of this type exist for coal and shale. Even the conclusion that a characterization program cannot be developed is useful because this fact will profoundly influence the types of work that can be done and the kinds of results that can be expected. Of equal importance is the need to define recovery costs in terms of resource-characterization parameters.

Work on flow properties in heavy-oil deposits depends on the physical structures of the formations, as well as on their depths, porosities, and dimensions. It is of interest to attempt classification according to these properties. The owner of an oil field will be interested, almost exclusively, in his own field. If every field is substantially different from every other field, a basic research program may not be fruitful.

\subsection{Thermal Recovery Methods}

To extract heavy oils, they must be mobilized, which is currently done by heating or by dissolution. The temperatures needed are 100 to $200^{\circ} \mathrm{C}$ and higher. A variety of methods has been used 
to heat oil fields. These include steam injection, hot fluid injection, hot $\mathrm{CO}_{2}$ injection, and in situ combustion. These techniques are currently applied empirically. Several operators have developed programs to model oil-field response to steam/ water treatments. At temperatures above about $350^{\circ} \mathrm{C}$, heavy oils begin to pyrolyse and release lower molecular weight gas and fluids, as well as non-volatile chars. Pyrolysis has profound and irreversible effects on flow properties through the deposits.

In situ combustion produces heat directly in the deposit, thereby obviating the necessity to transport thermal energy down a long pipe. It also appears to reduce environmental problems associated with power generation, since some of the exhaust gases from the burners are absorbed in the oil formations. However, the effects of the higher temperatures on the oil and sand, as well as the influence of hot exhaust gases from the combustion zone on oil-sand properties, are not well understood. A program of study of the effects of combustion on the physical (flow) and chemical properties of oil-sand formations should prove to be fruitful. Common to all of these thermal methods is the transport of heat by gases (steam, $\mathrm{CO}_{2}$, etc.), fluids such as hot water, or alkaline solutions. Thermal energy transports should be modeled quantitatively for various types of oil-sand formations and a theoretical effort aimed at improved understanding of thermal transports in low-porosity media might yield substantial rewards.

Theoretical modeling should be done of flow properties in oil-sand media under treatments such as steam drive, alkaline flooding, steam or $\mathrm{CO}_{2}$ drive, etc. Theoretical efforts should be closely coupled to tests. The empirical approaches actually used are often employed in the absence of detailed characterization of the field. Thus, when they are totally or partially unsuccessful, reasons for the failures are not generally apparent. 
Heating of a heavy oil deposit involves heat transport and fluid flows under conditions of high pressure and partial or total immiscibility. Transport of heat by conduction is so slow that we must rely on convective heat transfer in the field. Convection involves motion of gases, liquids or both through the field. Steam has a vapor pressure of 69 psia at $150^{\circ} \mathrm{C}$ and $225 \mathrm{psia}$ at $200^{\circ} \mathrm{C}$. If the field pressure exceeds these values at the specified temperatures, the steam will change to liquid water, which is much denser, has a much greater viscosity, and flows extremely slowly in capillaries wetted by oil.

The steam quality is an important parameter in steamdrive techniques. A part of the problem with hot water drive is that the water, being much less viscous than the oil, will move more rapidly through sandstone pores which are not wetted by oil. While this is desirable for heating, it introduces the heat in the wrong part of the formation. This area is susceptible to theoretical analysis and detailed modeling. The steam-water composition changes quickly and depends on field pressures and temperatures, as well as on source temperature.

Hot $\mathrm{CO}_{2}$ may have advantages over water-steam mixtures because it is a gas soluble in oil and, furthermore, oil/ $/ \mathrm{CO}_{2}$ solutions have lower viscosities than pure oil. However, $\mathrm{CO}_{2}$ is more expensive to use than water. In addition, $\mathrm{CO}_{2}$ also moves rapidly through the more porous parts of the field so that its use occurs effectively in a huff-and-puff mode. It is pumped into a closed field without open channels.

A study of the transport properties and phase behavior of $\mathrm{CO}_{2}$ in heavy oils is essential for understanding its use. Although some information of this type may already exist in unpublished industry reports, it is not generally available. 


\subsection{Chemical Additives}

Chemical additives have been used to improve the efficiency of the steam/water drive. In principle, the mechanism of oil release by hot water is to heat the oil first in the sandstone capillaries to the point where it expands and then flows. In contact with hot water, the oil will tend to form droplets and emulsions. The use of alkaline water enhances oil flows and emulsion formation, presumably by lowering the water/oil interfacial tension.

Water-soluble polymers have been used to increase the viscosity of the water and make its flow match the oil flow. Surfactants have also been used to enhance emulsion formation by lowering the surface tension of water and thus improve water-sandoil wettability.

A major problem with additives, including inexpensive alkali solutions, is the high loss rate of the chemicals to the sandstone formation. A study of the mechanism of this uptake is important in understanding whether the losses can be diminished. This type of research could provide important guidelines on the potential uses of additives.

Important in all of these considerations is the realization that many oil fields contain large amounts of brine and other salt deposits, which may significantly influence the phase behavior, flow and surface tensions of the oil-water-additive systems. Studies designed to explore the interactions and mechanisms of additive behavior should be extended to include the effects of locally occurring salt deposits.

One of the potentially interesting uses of additives relates to the movement of clays and fine sand particles in heavy oil deposits. The various fluid treatments used to recover the oil can initiate the movement of fine sand particles in the deposit. In general, this motion has a degrading influence on the permeability of the deposit. It is important to investigate the condi- 
tions under which these phenomena are produced and to explore the use of chemical additives which may retard the movement of fines. Thixotropic additives are used in drilling oil wells to prevent similar fine sand deposition, which would tend to impede or even freeze the drilling motion. Perhaps similar additives will be effective in heavy oil treatments.

\subsection{Environmental Problems}

Basic and applied research on environmental problems are discussed in Chapter 4. Here, we note only that an opportunity may arise in connection with the upgrading of heavy oils and tar sand oils in relation to heavy metal contents. Vanadium and nickel can occur in these oils in amounts up to $300 \mathrm{ppm}$. Methods for their removal and, possibly, recovery should be explored. At $100 \mathrm{ppm}$ each, there are about $0.4 \mathrm{oz}$. of nickel and $0.4 \mathrm{oz}$. of vanadium in every barrel of crude. Nickel and vanadium are both valuable metals. Sulfur is one of the most important industrial chemicals. Nitrogen may lead to fertilizers. A program to recover and use trace metals, as well as sulfur and nitrogen compounds, could pay dividends to the fossil fuel industry and might be worth some federally sponsored effort. 
CHAPTER 6

UPGRADING AND REFINING

\subsection{Introduction}

Potential problems associated with upgrading and refining of heavy oils and bitumens produced in various enhanced oilrecovery and tar-sand extraction processes are very different from those associated with synthetic crudes produced from oil shale and coal. Colorado shale oils produced by state-of-theart retorting technologies are mainly distillates and are chemically and structurally different from petroleum crudes in heteroatom contents, particularly nitrogen, oxygen, arsenic, and iron. Synthetic crude fractions for down-stream refining from direct coal-liquefaction processes such as EDS, SCR-II and H Coal are also mainly distillates and are again chemically and structurally different from petroleum crudes, being very high in ring structure and aromatic content and correspondingly different in hydrogen concentration. The heavy oils and bitumens (hereafter collectively referred to as residua) discussed in this chapter are chemically and structurally similar to many petroleum crudes, particularly asphaltinic crudes, but may be very much higher in resid content. For this reason, modern refining technologies being practiced on heavy petroleum crudes can be employed with confidence on these materials.

The major problem envisioned for a refiner facing a substantial shift in crude input to these higher resid content oils is bottom of the barrel conversion capacity. Further discussion in this chapter will be limited to the residuum conversion and upgrading to produce specification transportation fuels. Upgrading for use as power plant fuels will not be discussed. 


\subsection{Residuum Conversion Alternatives}

More than a dozen residuum conversion processes and combinations are commercially practical process alternatives and may be used for converting the bottom of the barrel (residuum) into light products. These processes are summarized in Table 6.2-1.

Each of these 1isted processes has attributes and disadvantages, depending on the specific refinery application, viz.:

a. Visbreaking is usually the least expensive process but provides only a modest degree of residuum conversion. Its applicability is further constrained by oil-quality considerations involving stability and compatibility.

b. Delayed coking is relatively easy to implement, requires moderate investments, provides a high degree of conversion, but may produce a large volume of low value coke. Residuum desulfurization, coupled with coking, reduces the volume of low valued by-product coke and produces mid-distillates, but it is relatively expensive.

c. Fluid coking is similar to delayed coking in many respects but produces higher yields. However, the coke produced usually has a lower value and the gas oils are somewhat more difficult to refine.

d. Gasification, followed by Fischer-Tropsch synthesis and including methanol production, is commercially feasible but expensive.

e. Solvent deasphalting is an especially attractive option for converting residua that contain very high levels ( $>300 \mathrm{ppm}$ ) of metals. Since deasphalting is accomplished in a separation process, the deasphalted oil must usually undergo extensive bydrotreating and cracking before conversion to 1 ight products. In addition, a low quality pitch is formed which may be difficult to dispose of. 
Table 6.2-1 Residuum conversion alternatives.

Thermal processing: delayed coking, fluid coking, visbreaking; the Japanese Kureha process which involves high temperature thermal cracking.

Fischer-Tropsch synthesis including methanol production.

Solvent deasphalting.

Residuum catalytic cracking.

Hydroprocessing, including desulfurization, hydrocracking, asphaltene hydrocracking.

Combined processing using combinations of the preceding alternatives. 
f. Resid catalytic cracking alone or combined with residuum hydrotreating are characterized by conversion capabilities similar to coking, but the processes are expensive, produce large quantities of high-pressure steam, and the product is primarily gasoline.

g. Catalytic residuum hydrotreating ( $\mathrm{H}-\mathrm{Oil}$ or $\mathrm{L}-\mathrm{C}$ fining) is relatively expensive, produces relatively low quality distillate products and residual tar, and some plants may have relatively low operating factors.

In evaluating' residuum processing alternatives, economics play an important role. Each of the following factors affects the economic outcome significantly: (i) product yields and qualities; (ii) by-products; (iii) investments; (iv) operating costs, particularly fuel requirements; (v) the extent of process commercialization, i.e., the proven record of operating success; (vi) environmental controls. The volume of light products produced is particularly important in view of the differentials that have existed in the marketplace between light and heavy products.

Another important consideration is that of by-product disposal, which is common to all residuum conversion processes. In fact, the final process selection may depend upon whether or not there is an economic outlet for the by-product. In Table 6.2-2, we list by-products associated with the specified residuum-conversion alternatives.

In summary, there is a variety of residuum conversion a1ternatives available for the design of new refineries or for modification of existing refineries. These will accommodate substantial increases in the conversion of heavy oils and bitumens to transportation fuels. All procedures have costs and problems. The optimal cost-effective process selection will be highly site- and project-specific. 
Table 6.2-2 Residuum conversion of by-products.

Conversion to special fuels:

a. high viscosity, high sulfur tar or pitch from residuum hydrocracking, solvent deasphalting;

b. high sulfur delayed coke;

c. low to medium sulfur delayed coke;

d. fluid coke;

e. low-btu fuel gas from flexicoking.

Use of non-liquefiable by-products for energy production:

a. steam or electric power from residuum fluid catalytic cracking or partial oxidation.

Use for by-product upgrading:

a. low-sulfur coke from coke calcination;

b. hydrogen by gasification of tar or coke. 


\section{$6.3 \quad$ Research Needs}

Many of the residuum-conversion alternatives, particularly the less expensive ones not employing high cost manufactured hydrogen and extensive hydrocracking conversion, involve some form of hydrogen disproportination. Thus, parts of the resid are converted to a liquid with higher hydrogen to carbon ratio and the concurrent production of solids with lower hydrogen to carbon ratio or of liquid by-products of marginal market value. Research programs should include both primary conversion technologies and costeffective recovery of energy values from by-products.

The following suggested studies could lead to the development of more cost-effective processes:

a. More comprehensive knowledge is needed of the molecular compositions and structures of residua, including bitumens. Particularly important are identifications of asphaltenes and metals contents.

b. The mechanisms and selectivity of asphaltene conversion reactions require study.

c. New reactions should be sought for the removal of sulfur and metals from residuum and by-products of residuum conversion.

d. The kinetics of petroleum coke gasification processes, including the use of catalysts, should be investigated.

e. Improved catalysts are needed for residuum hydrocracking and should be sought through basic research.

f. Novel and efficient processes are needed for recovering energy values from high-sulfur cokes and tars. 
CHAPTER 7

COSTING OF OILS FROM EOR AND UTAH TAR SANDS

Some cost information and data will be found in most of the site-visit reports.

While we have not arrived at generally useful cost estimations for oils from EOR and Utah tar sands, the attached Appendix 7-I by K. E. Phillips highlights the technical areas in which studies must be performed in order to refine cost estimations prior to commercialization.

For EOR, the principal uncertainties deal with reservoir characterization and with achievable resource recovery using diverse technologies.

For oil recovery from some of the Utah tar sands, primary uncertainties deal with a possible cost advantage derived from the use of oil-wet sands without intermediate water layers, bitumen production with lower sulfur contents, and the possibility of eliminating an intermediate centrifuging step in the primary clean-up of bitumens; a disadvantage is associated with the initial production of Utah bitumens with greatly increased viscosity compared to the bitumens obtained from the Athabasca tar sands.

Since EOR and bitumen recovery from Canadian tar sands are currently commercial processes, we are not concerned with establishing commercially competitive industries but rather with cost reductions for processes which are known to be economically viable. 


\author{
Appendix 7-I \\ COSTING OF OIL FROM HEAVY OIL \\ SOURCES AND TAR SANDS ${ }^{\dagger}$
}

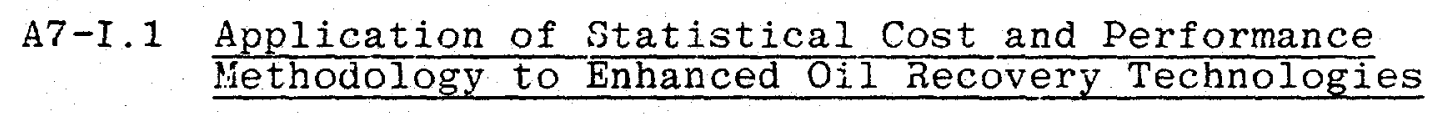

We first comment briefly on a previous Rand study. ${ }^{1}$ This pioneer plants study was an attempt to design statistical methods for (a) applying proper contingencies to conventionally derived engineering estimates and (b) for predicting overall levels of plant performance during the first year after startup. The statistical equations that were developed applied to projects that were clearly capital intensive and that contained any number of continuously linked process units, i.e., the models were calibrated toward process plants.

In current form, neither the mathematical structure of our models nor their parameter estimates are suitable for direct application to EOR technologies. However, the logic and some of the technical issues captured in the equations appear relevant and suggest some reasonable directions for future EOR research.

A common structure underlying both the cost and performance equations derives from a recognition that uncertainties can be quantified if they can be approximated by measures of how much is known (i.e., what has actually been accomplished) concerning the stage of process development. A second and separate area, relevant mainly for understanding project costs, concerns the state of information about the physical project itself, i.e.,

Prepared by K. E. Phillips, the Rand Corporation, 1700 Main Street, Santa Monica, California 90406.

$1_{\mathrm{E}}$. Merrow, K. E. Philitps, and C. Myers, "Understanding cost Growth and Performance Shortfall in Pioneer Process Plants," The Rand Corporation, Santa Monica, California 90406, Report No. R-2569, September, 1981. 
locational specifics and site requirements that must (at least for process plants) affect the civil and structural engineering designs and, consequently, overall project costs. The first area can probably be addressed via statistical predictive models for EOR technologies using information that now exists in the literature. The second area appears to have no direct analogy at the present time.

For our research on first-of-a-kind plants, we focused on the level of process development to help determine the state of knowledge about the basic conversions and unit operations going on within the plant itself. We developed several measures to approximate the level of process understanding including: (a) difficulties encountered in specifying the balance equations for the plant; (b) problems with impurity buildups and recycle streams; (c) problems with waste handling; (d) assessments of the general stage of process R\&D. These measures were incorporated into statistical models to isolate the cost and performance difficulties associated specifically with unknowns about the major conversions and unit operations within the system.

In parallel fashion, a potentially useful area of research involving EOR technologies would first identify parameters that are consistent and replicable from one technology to the next and then to develop variables to approximate the stage of uncertainty that remains about each relevant parameter. The latter task presents the greatest challenge for it requires not only isolating the critical issues governing project costs and performance but, more importantly, it requires the development of appropriate measurement scales for these variables. During our research on first-of-a-kind plants, the first 18 months were required for accomplishing these general tasks.

The second area of interest, the measurement of project definition, was found to be critical for the analysis of project costs but not for understanding plant performance. It is in 
this area that the analogy between our research and application to EOR technologies is weakest. Our key findings showed that the ability to estimate project costs accurately depended upon the complete specification of the project site, along with measures of the level of engineering definition associated with each critical site characteristic. Based on discussions with FERWG members, the arguments presented in the literature, findings presented at the DOE Contractor Conference, and preliminary indications given at the AOSTRA meetings, it appears that, given the current state of technology, developing an accurate horizontal profile of any reservoir that is a candidate for some EOR method is both costly and subject to considerable errors. This fact suggests that the portion of total cost that is related to information about the project site will be difficult to obtain. Further complicating the problem is the general relationship that exists between thorough site characterization and the recovery of original oil in place. In other words, contrary to our findings for new process plants, system performance in EOR technologies is dependent on thorough site characterization.

In those areas where current information can contribute to greater understanding through statistical models, such work is worth pursuing. The primary difficulty is that process aspects represent only a portion of the total information requirements for accurate prediction of costs and ultimate recovery. We conclude that, when thinking about the applicability of a statistical methodology for EOR technologies, the limitations posed by reservoir characterization constitute a binding constraint. This statement is consistent with arguments offered in the past. 
A7-I.2 The Costs and Performance for Recovering and Processing Utah Tar Sands and the Relevance of the Suncor and Syncrude Experience

We have no detailed data on project-specific cost estimates for a substantial extraction and upgrading plant designed to process Utah tar sands. Consequently, we are unable to suggest what level of cost contingency or first year performance would be appropriate for a given level of engineering and process development required to generate a real cost estimate. It is possible, however, to make some observations concerning the following points: (a) the manner in which handling and processing requirements for Utah tar sands might differ from those of Canada; the general direction in which these differences might influence costs.

Regarding concern about lessons from the Canadian experience, some general observations on the design differences between the Suncor and Syncrude plants might prove helpful for isolating performance problems that derive not from feedstock differences (since both plants process the same Athabasca sands) but from design differences between the two units.

Cost estimates for the Suncor plant were close approximations to actual project costs. Problems were confined primarily to performance difficulties that plagued the project during its early years of operation. The most severe difficulties pertained to materials handling and not to the process portions of the plant. A notable exception involved failures in the bitumen-coke-fired power boilers. More specifically, the large wheel and bucket excavators suffered severe damage (i.e., millions of dollars in costs) when encountering the frozen and abrasive tar sands. Solutions to this problem involved explosive rubblization of the seam face in winter and designs for stronger teeth on the excavators. Furthermore, belts used to convey the excavated tar sands suffered severe clogging and efforts to unclog them using conventional 
kerosene solvent resulted in belt destruction. Solutions here involved the development of new rubber compounds for belt fabrication. All of these technical difficulties were eventually resolved and the plant reached steady state performance at design capacity approximately 24 months after the July 1967 start-up date.

Available information on the Syncrude unit is sketchy. However, the known problem areas occurred at precisely those points where syncrude chose to deviate from the Suncor experience. Specifically, the use of fluid coking, as opposed to delayed coking, and the use of drag-line in place of wheel-and-bucket excavation, both resulted in performance problems and necessary correction costs. The Syncrude plant, therefore, experienced problems both in materials handling and in a major portion of the process.

These brief comparisons lead one to expect that the mining and materials handling operations in a Utah tar sands plant will pose some challenges, especially if the chosen techniques deviate from those with which there is available commercial experience. Since these problems emerge after construction, during the first year of startup; product costs may suffer considerably. Replacement of equipment and hardware will affect the capital cost portion of the product costs, while the loss in plant performance will drive product costs even higher.

We now address what may prove to be significant design differences between the process portions of the Canadian plants and those that would be built to handle Utah tar sands. The feedstock differences between the Canadian and Utah sands might affect the plant design in three specific areas, including (a) environmental and waste handling difficulties, (b) dilution or visbreaking requirements for the extracted bitumen, and (c) sulfur-removal requirements. The environmental issues related to tailing-pond effluents and the danger of perpetual emulsions, 
that cannot be safely disposed of, may be a lesser problem in Utah. We expect these differences to follow from the oilwet character of the Utah tar sands in contrast to the water-wet sands in the Athabasca deposit. This important difference between the two feedstocks may contribute significantly toward obtaining the political and environmental clearances to move ahead with this particular alternative energy source in the United States. Furthermore, one can reasonably conclude that a plant processing Utah sands would enjoy considerable cost savings if the earth moving and expensive equipment for tailings pond construction can be dispensed with.

The second issue of concern, dilution of the extracted bitumen for viscosity reduction, may affect costs for the Utah plant in a negative manner. The Utah sands are between 2 and 5 orders of magnitude more viscous than those in the Athabasca deposit. Where the Suncor and Syncrude plants achieve post-extraction viscosity reduction with simple naptha dilution, more severe treatment might be required for handling the Utah feedstocks. An extra process step, possibly a mild thermal cracking or visbreaking, may be required to achieve the required viscosity characteristics for further processing.

A third area of interest might involve the extent to which a plant in Utah could reduce the costs required for the initial cleanup of the extracted and viscosity-treated bitumen. The Suncor plant, for example, utilizes centrifuging to remove water and grit from the partially processed feedstock. Since Utah contains oil-wet tar sands and because clays are confined to easily detectible lenses, a processing facility located in Utah may achieve some cost reduction by eliminating the centrifuge step. Since the literature on process-equipment failures indicates abnormally high failure rates on rotating machinery, the elimination of this step could also improve long-run plant performance, as well as reduce the costs of plant maintenance. 
A final point of interest involves sulfur-removal requirements. The Utah tar sands contain only $10-13 \%$ of the average sulfur level in the Athabasca deposits. The Canadian plants each require two separate sulfur removal operations. The first is accomplished when the bitumen is coked (delayed coking at suncor and fluid coking at syncrude) to remove bottoms and heavy trace metals. The second is accomplished (at Suncor) after the coked bitumen is sent to distillation towers for fractionation into napthas, middle distillates and fuel oils. In separate unifiers, each stream is hydrogenated under pressure to remove more sulfur and also nitrogen and oxygen. At Syncrude, the coke bitumen is not fractioned with separate stream treatment but there is a sulfur-removal plant that treats the sour fuel gas. The synthetic crude and the coke retain the rest of the sulfur.

If a plant located in Utah were designed only for the production of synthetic crude, the much lower sulfur levels might justify eliminating much of the post-coking sulfur removal. Perhaps a lower sulfur crude would yield lowèr sulfur coke, while cleaner off gases could still be obtained. One could, therefore, expect significant cost savings in sulfur removal. On the other hand, if the Utah plant were designed to process the crude on site, as is done by Suncor, and produce final products, additional sulfur removal might be required. However, some cost savings should still be realized because of the lower severity of sulfur treatment. 


\title{
EXTENSION
}

of Studies by the Fossil Energy Research Working Group-III

\author{
March 1, 1981 -- December 31, 1981: \\ OIL RECOVERY FROM TAR SANDS AND HEAVY OILS \\ STATEMENT OF WORK
}

The objective of this addition to the current program is to conduct an independent assessment providing for identification of research needs associated with oil recovery from tar sands and heavy oils, using all available means for effective processing of these resources. This work is expected to include recommendations to DOE for research programs that can best contribute to the successful long-term development of new oil recovery technologies from tar sands and heavy oils.

In fulfillment of the project objectives, the contractor will be expected to work with both the academic community and industry. The assessment will consider all of the basic disciplines involved in the development of techniques for oil recovery from tar sands and heavy oil sources. Members of FERWG will be expected to gain first-hand familiarity with operational aspects of usable technologies through site visits, interviews, examination of development studies and reports, and other means.

Typical of the kinds of long-range issues that will be addressed are the following:

1. How much cheaper or more efficient may we expect oil recovery from tar sands and heavy oils to be in the future, compared with those that are now in use or under development? 
2. Can we identify the scientific and engineering directions that will be useful in making these technological improvements?

3. What are likely near-term and long-term environmental impact assessments for large-scale commercialization of these technologies?

4. What scientific and technical areas that are key to the success of ongoing oil recovery $R \& D$ from tar sands and heavy oils are still "open" areas for research and are likely to profit from a broader or deeper look?

5. What disciplinary or interdisciplinary fields or research ideas should be supported because they hold long-range potential for generating innovative and useful technologies in these fields? 
MAIL CODE B-010

LA JOLLA, CALIFORNIA 92093

TELEPHONE: (714) $452-4284$

January 5,1981

Enclosed you will find a preliminary version of a report dealing with oil recovery from tar sands ani heavy oils, which has been prepared by the DOE Fossil Energy Research. Working Group. A very long Appendix contains site-visit reports and is not included.

In view of your acknowledged expertise in these programs, I would greatly appreciate your reviewing the enclosed document and comenting in writing as appropriate. We prefer responses that we may bind and include in our final report, which will be widely distributed. Any errors to which you call our attention will, of course, be corrected in the final text. However, important omissions and differences in points of view are best handled by including your response over your signature.

Please accept my sincere expression of appreciation for your time and advice in preparing a document that may be of greater utility to policy planners.

$$
\text { Sincerely yours, }
$$

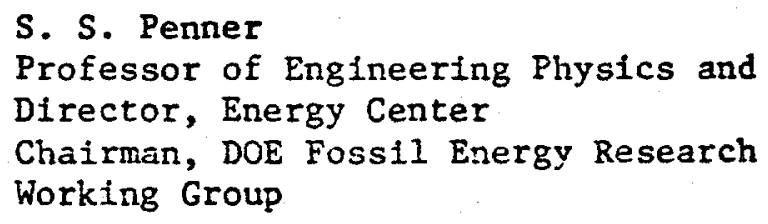

SSP/In

enc1. 
January 19, 1982

Dr. S. S. Penner

Chairman, DOE Fossil Energy Research

Working Group

Mai] Code B-010

La Jolla, California 92093

Dear Dr. Penner:

I have read "Assessment of Research Needs for $0 i 1$ Recovery from Heavy $0 i 1$ Sources and Tar Sands", as requested in your letter of January 5, 1982. In summary, my opinion is that the report contains a good description of the state-of-the-art of tar sands recovery methods. It also clearly points out the necessity to develop site-specific recovery techniques for each field case. It does not, in my opinion, make a clear case for additional basic research.

Production from U. S. tar sands is almost non-existent. To make a case for tar sands basic research the report would need to discuss: (1) What are the factors that inhibit production of U. S. Tar Sands? (2) On which of these factors could research make a difference? (for example research could not change a lean tar sand into a richer one).

Additional analysis, such as used in section $3.2,2$ would be helpful in qualifying the need for research.

Much is already known about multi-phase fluid flow, heat transfer, combustion, kinetics, interfacial forces, wetting, capillarity, sandstone and carbonate deposition, fracturing, etc. This knowledge is being used currently in exploitation of heavy oils. You need to show how additional knowledge in one or more of these areas would be beneficial to tar sands.

You are to be commended for attacking a difficult problem. Tar sands have been known in the U. S. for many years. Many have tried to exploit them, yet few have succeeded. Current higher energy prices should help. But the technical problems remain formidable. Perhaps the work of your committee will help to stimulate some answers.

Yours truly,

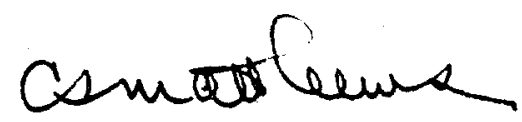

C. S. Matthews

CSM:rgb

Sr. Consulting Petroleum Engineer Head Office 
Department of Energy

Bartlesville Energy Technology Center

P.O. Box 1398

Bartlesville. Oklahoma 74003

January 25, 1982

Dr. S. S. Penner

Professor of Engineering Physics and

Director, Energy Center

Chairman, DOE Fossit Energy Research

Working Group

University of California, San Diego

Mail Code B-010

La Jolla, CA 92093

Dear Dr. Penner:

Thank you very much for providing us with the opportunity to review the third revised draft of a report dealing with oil recovery from tar sands and heavy oils prepared by Fossil Energy Research Working Group- IIIA (FERWG-IIIA). The attached copy has been marked up for your use. In addition, we would like to make some comments about the report.

In gereral, the report is well written. The one aspect of the report that was noted and commented on by all BETC reviewers was that of prioritization. One reviewer's remarks that reflect those of the others is as follows: "Important research areas are provided [by] a general 'shopping 1 ist' approach in the report, but are only given brief prioritization in Section $G$ of the Executive Summary. It seems that some systematic development of the research need priorities should be provided."

When budgets are limited, setting priorities serves a useful purpose in establishing a research program. BETC would like to be involved in any discussion of priorities for tar sands and heavy oil research that the FERLG-IIIA may have in the future.

The members of the Fossil Energy Research Working Group have made a real contribution in terms of time and thought to the preparation of this document. We would like to express the appreciation of the Bartlesville Energy Technology Center for this effort.

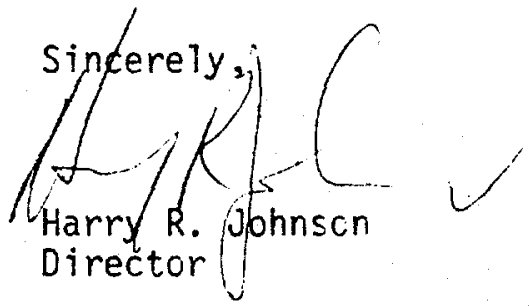




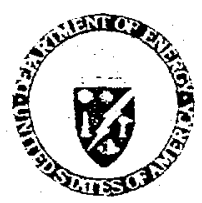

Department of Energy

San Francisco Operations Office

1333 Broadway

Oakland.California 94612

February 3, 1982

Professor S. S. Penner

Director, Energy Center

University of California

Mail Code B-010

La Jolla, CA 92093

Dear Dr. Penner:

Our Fossil Energy Division at Oakland has reviewed the FERWG draft report on Heavy Oil and Tar Sands research. We believe that FERWG has done a good job in pointing out research needs and we have no further comments to make on the draft. Our previous comments made on two previous reviews of report drafts are adequately covered in the current report. Thank you for the opportunity to provide input to your group on this very important and timely exercise.

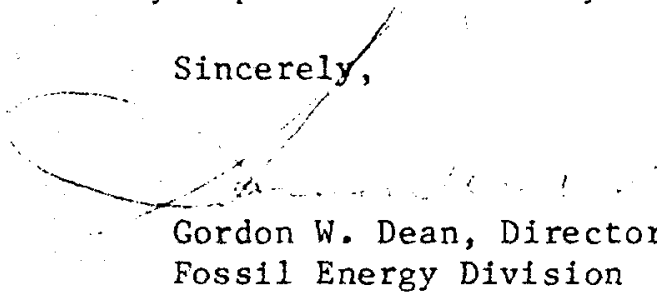


American Petroleum Institute

2101 L Street, Northwest

Washington, D.C. 20037

202.457.7170

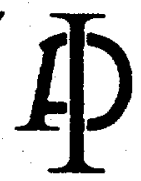

Ronald $L$. Jones

Refining Director

February 8， 1982

Ref: M-15

Mr. S. S. Penner

University of California, San Diego

Mail Code B 010

La Jolla, CA 92093

Dear Professor Penner:

We have reviewed the documents attached to your letter of January 5, 1982, and find that technical review by the Institute is not needed. Several members of Fossil Energy working Group IIIA lead technical activities covering tar sands and heavy oil subjects within the Institute. Thus the use of our review mechanism would be redundant in this case, particularly in view of the advanced stage of development of this report.

Please do not interpret this to reflect any unwillingness by the Institute to participate in future work by your group. We would like to participate when we can be helpful to the Department.

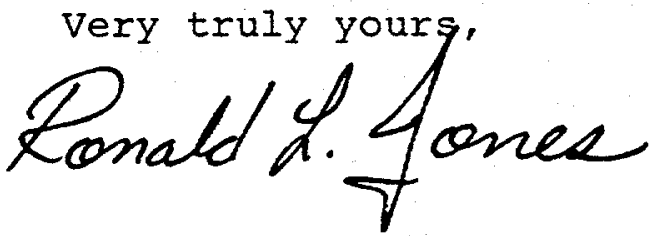




\section{UNIVERSITY OF SOUTHERN CALIFORNIA}

UNIVERSITY PARK

LOS ANGELES, CALIFORNIA 90007

SCHOOL OF ENGINEERING

DEPARTMENT OF CIVIL ENGINEERING

March 15, 1982

Dr. S. S. Penner

University of California, San Diego

Energy Center

Mail Code B-010

La Jolla, CA 92093

Dear Dr. Penner:

I and my associates have thoroughly read your report dealing with oi] recovery from tar sands and heavy oil, which you have prepared for the DOE Fossil Research Energy Group. Let me say that the document is well prepared. However, I personally feel that the following aspects need to be stressed further.

One very important aspect is the need to characterize for heavy oil as well as the bitumens of tar sand. In my definition, both materials are a mixture of bitumen and oil (see my enclosed statement for the First International Conference on Heavy $0 i 1$ and Tar Sands). I feel that classification of heavy oil and tar sands, as well as their chemical constitution is very important for recovery. Please also refer to my suggestion at the New York UNITAR Origanizing Committee Meeting, as well as the paper presented at the Second International Conference on Heavy $0 i$ and Tar Sands, which are also enclosed. The fact is if we understand the chemical nature of the oil, then the recovery method can be developed according to the difference in the composition of heavy oil. For example, an asphaltene-rich oil will precipitate out and plug the pores during recovery if $\mathrm{CO}_{2}$ is used.

Another point is, in some selected reservoirs, microbes may enhance heavy oil recovery. DOE sponsors several projects related to microbial enhancement of oil recovery. Some bacterial species are able to utilize heavy ends. The reduction in oil viscosity supposedly leads to enhanced recovery. Microbial enhanced oil recovery has also been known to occur by other mechanisms like biosurfactant and biogas production, etc. More detailed work on characterization of heavy components needs to be done. In some information on component properties is necessary:

1) the composition of heavy oil, and

2) the possible utilization of the heavy components by microbes.

I hope the above will be helpful in your decision making process. I apologize for the delay in answering your letter.

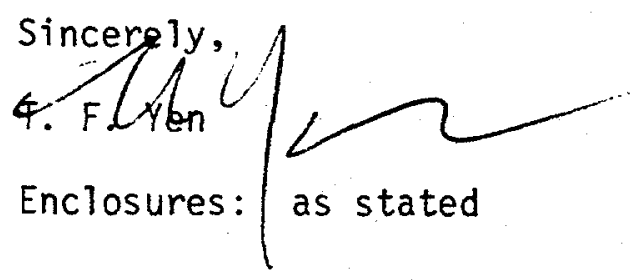

